\title{
Cueva Negra del Estrecho del Río Quípar: A dated late Early Pleistocene Palaeolithic site in southeastern Spain
}

Michael J. Walker ${ }^{1,2, a}$, María Haber Uriarte ${ }^{1,3, a}$, Antonio López Jiménez ${ }^{1, a, b}$, Mariano López Martínez ${ }^{1, a}$, Ignacio Martín Lerma $^{1,3, a}$, Jan van der Made ${ }^{4, b}$, Mathieu Duval ${ }^{5,6, c}$, Rainer Grün ${ }^{5, c}$.

1 Murcian Association for the Study of Palaeoanthropology and the Quaternary (MUPANTQUAT)

2 Dept. of Zoology and Physical Anthropology, Faculty of Biology, Murcia University, Spain

3 Dept. of Prehistory, Archaeology, Ancient History, Mediaeval History and Historiographical Sciences, Faculty of Letters, Murcia University, Spain

4 Museo Nacional de Ciencias Naturales, Consejo Superior de Investigaciones Científicas (CSIC), Madrid, Spain

5 Australian Research Centre for Human Evolution, Environmental Futures Research Institute, Griffith University, Australia

6 Centro Nacional de Investigación sobre la Evolución Humana (CENIEH), Burgos, Spain

a Field team; b palaeobiology; c geochronology.

Corresponding author: mjwalke@gmail.com

Conflict of interest: The authors declare that they have no conflict of interest.

\section{$\underline{\text { Abstract }}$}

Systematic excavation and multidisciplinary research undertaken over three decades have deepened our understanding of the early Palaeolithic archaeology at Cueva Negra del Estrecho del Río Quípar (Caravaca de la Cruz, Murcia, Spain). New results from biochronology and combined ESR and U-series dating corroborate previous magnetostratigraphy, placing the entire excavated sequence between the Jaramillo sub-chron and the Matuyama-Brunhes boundary (i.e., ca. 990-772 thousand years ago [ka]); palaeontological and palynological findings reflect temperate environmental conditions. A bifacially-flaked limestone hand-axe was excavated one metre below the top of the Pleistocene sequence. The Equus cf. altidens tooth that provided the ESR estimate was excavated one metre below the hand-axe. Throughout its five-metre-deep sedimentary sequence, small nodules, fragments, and struck flakes make up the bulk of the Palaeolithic assemblage. Stratigraphical analysis points to undisturbed continuous sedimentary deposition above a layer of ashy sediment, encountered $4.5 \mathrm{~m}$ below the top of the Pleistocene sequence, which contained thermallyaltered bone and heat-shattered chert cores and flakes. Cueva Negra is among the earliest European sites with firm evidence of combustion.

\section{Introduction}

The Iberian Peninsula offers the most complete record of Early Pleistocene human presence in western Europe. An important site in the south-east of the peninsula is Cueva Negra del Estrecho del Río Quípar (Figure 1). Like other well-documented sites, it lies between the Mediterranean coast and a N-S line passing through Madrid (Figure 2). From $\mathrm{N}$ to $\mathrm{S}$ they include not only the Atapuerca Sima del Elefante and Gran Dolina sites (Arsuaga et al. 1999, 2001, 2014; Bermúdez de Castro et al. 1997, 2011, 2013a,b, 2017; Carbonell et al. 1995, 1999, 2008; de Lombera-Hermida et al. 2015; Duval et al. 2018; Falguères et al. 1999; Huguet et al. 2017; Mallol 1999: Parés et al. 2006, 2013, 2018; Rosas et al. 2006; Terradillos 2010), but also, closer to the Mediterranean, Vallparadís (García et al. 2011, 2012; Martínez et al. 2010, 2014), Barranc de la Boella (Vallverdú et al. 2014), Alto de las Picarazas (Vicente Gabarda et al. 2016), and the eastern Andalusian Fuente Nueva-3 and Barranco León-5 sites (Barsky et al 2015; Fajardo 2009; Gibert et al. 1998; Martínez-Navarro et al. 1997; Toro-Moyano et al. 2003, 2009, 2010, 2011, 2013). Their chronologies show that early Palaeolithic assemblages of pebble tools, choppers and flakes began to include bifacially-flaked large cutting tools such as a cleaver (Barranc de la Boella) and a hand-axe (Cueva Negra) ca. 0.9 - 0.8 Ma (i.e., ca. 900 - 800 ka). These tools are accompanied at Cueva Negra by evidence for the ability to tend fire, hitherto unrecorded in Europe at that time. Cursory exploration of the Cueva Negra sediments in 1981 (Martínez Andreu et al. 1989) paved the way for a programme of systematic excavation that commenced in 1990 since when it has continued annually and provided the abundant finds and data that indicate the antiquity of the site (Walker et al. 2013, 2016a). 

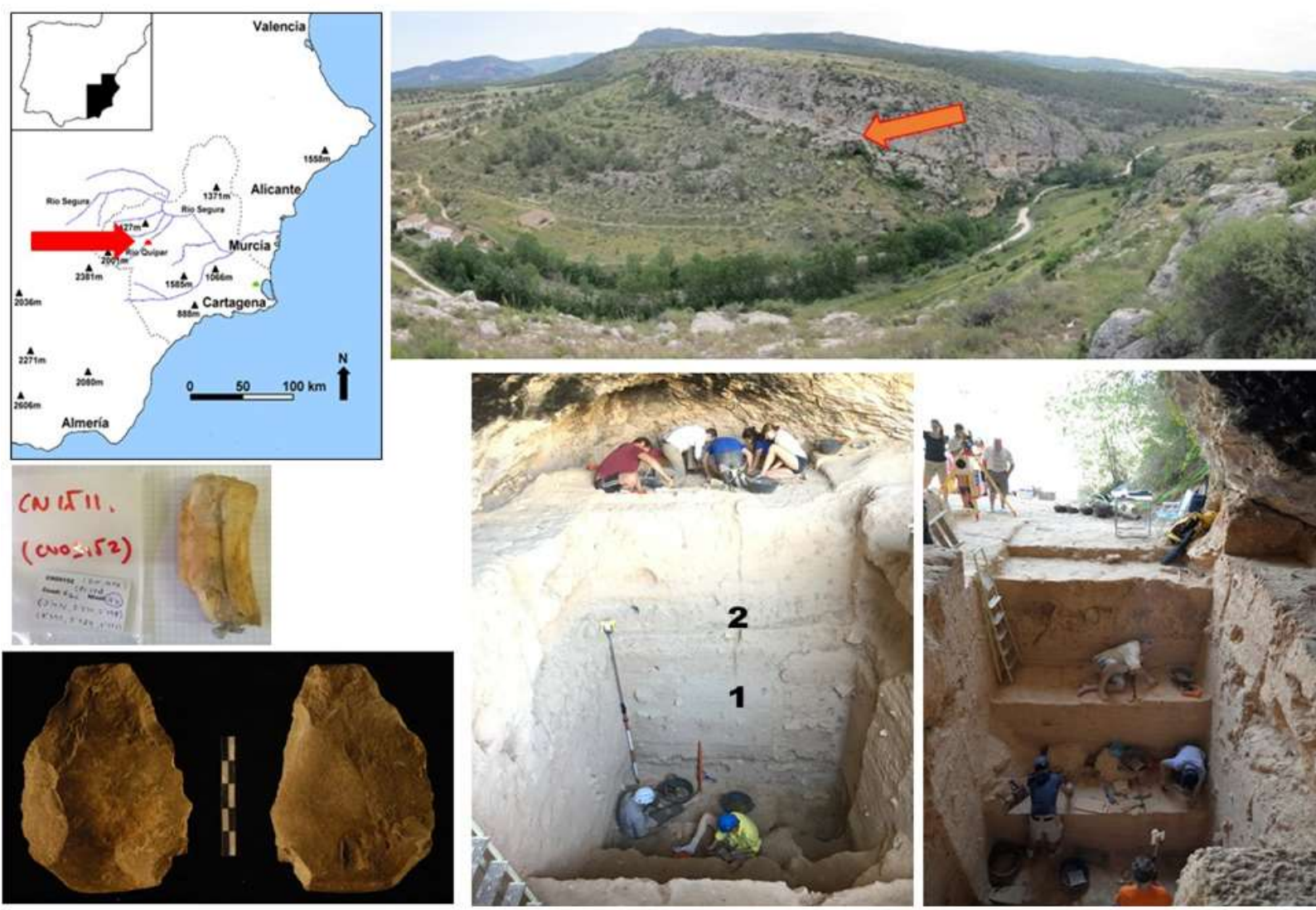

Figure 1. Top left: Location of Cueva Negra. Top right: Cueva Negra above the Quipar Gorge. Middle left: Fossil equid tooth CN1511. Bottom left: Bifacially-flaked hand-axe. Bottom centre: Excavation section showing 1 approximate depth from which CN1511 was dated, and 2 approximate depth from which the hand-axe was excavated.

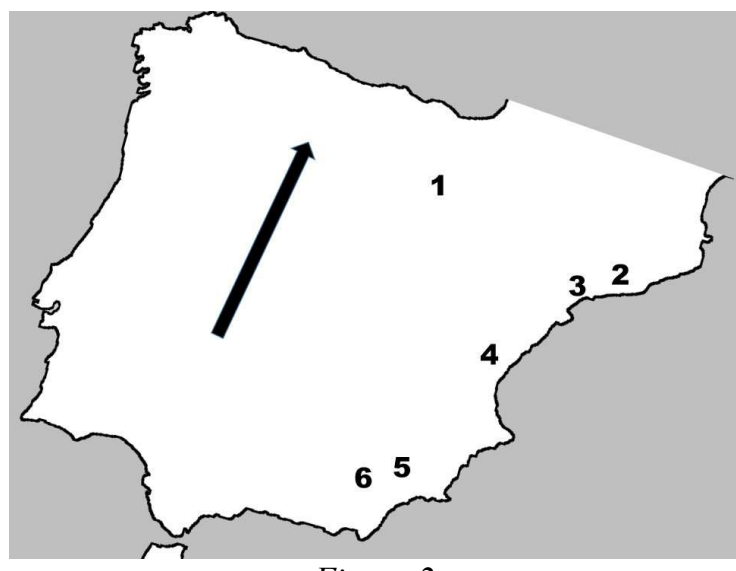

Figure 2

1 Atapuerca Sima del Elefante and Gran Dolina

2 Vallparadis 3 Barranc de la Boella 4 Alto de las Picarazas

5 Cueva Negra del Estrecho del Río Quípar 6 Fuente Nueva and Barranco León Arrow points North. 


\section{Context}

\section{Geographical location}

Cueva Negra del Estrecho del Río Quípar is a large, north-facing, rock-shelter (ca. 10x10 m in area), in Upper Miocene (Tortonian) biocalcarenite rock, lying at $740 \mathrm{~m}$ above sea level, a.s.1. (38 $02^{\prime} 12.5^{\prime \prime} \mathrm{N} ; 1^{\circ} 53^{\prime} 5.8^{\prime \prime} \mathrm{W}$ ) on the right bank $40 \mathrm{~m}$ above the Quípar River where it flows northwards from a one-kilometre-long gorge (the Estrecho, i.e., "the Narrows") below the hamlet of La Encarnación in Caravaca de la Cruz municipality (Murcia, Spain) (Figure 1). The Quípar is a tributary of the Segura River that reaches the Mediterranean Sea $110 \mathrm{~km}$ E of Cueva Negra, even though the cave lies only $70 \mathrm{~km} \mathrm{~N}$ of the Murcian coast. Important geological faults determine the alignment of tributaries in the Segura drainage basin. The Estrecho follows the sinistral reverse Quípar Fault, active since the Late Miocene (Messinian). Activity caused uplift of the right bank of the river, thereby saving from riverine erosion the fine-grained fluviatile sediments that had accumulated in Cueva Negra under conditions of low transport energy by intermittent overflow of an erstwhile swampy lake fed by the Quípar during the late Early Pleistocene. The Quípar enters the gorge at $725 \mathrm{~m}$ a.s.l. and leaves it at $690 \mathrm{~m}$ a.s.l.. The height of the land above sea level during the Early Pleistocene is unknown. The Upper Miocene (Tortonian) calcarenite formed under the Tethys Sea, arising to become a shoreline surface in the Upper Pliocene. Cueva Negra is a vestige of a trapezoidal endokarstic cavity that likely developed in relation to low-lying lagoons or lakes.

\section{Lithostratigraphy}

The fluviatile sediments inside Cueva Negra include clasts eroded from the cave roof and walls. Palaeolithic and faunal remains are present throughout the five-metre depth, implying frequent intervals when the cave was dry, perhaps seasonally. Preliminary microsedimentological analysis shows alternation between archaeological and sterile levels throughout the sequence, suggesting discontinuous Palaeolithic presence at the cave (Fernández et al. 2018). The sedimentary sequence (Figure 3) shows no significant interruption or disturbance of the successive stratigraphical complexes (Complex 2 - Cx.2, Complex 3 - Cx.3-1, and Cx.3-2; see Figure 3, column A), perhaps deposited during a relatively short period of geological time by fundamentally uniform, homogeneous alluviation (Angelucci et al. 2013; pace Jiménez-Arenas et al. 2011), albeit with a minor interruption at the top of Cx.3-1 in the nature of an incipient palaeosol with erosive traces (Angelucci et al. 2013). Detection of possible discontinuities had led to designation of notional "lithostratigraphical units I-VI" (see Figure 3, column B) as a precautionary measure during manual excavation; this is carried out in step-wise fashion in a wide trench in order to optimise entry of daylight and facilitate safe access to deep levels whilst maintaining stability of profiles (Walker et al. 2006). Subsequently, detailed sedimentary micromorphological analysis (Angelucci et al. 2013) showed some of these "units" to be superfluous, which is why they are placed between inverted commas wherever they are mentioned in this article. Manual excavation was undertaken in horizontal spits of varying thickness (Figure 3, column C). 


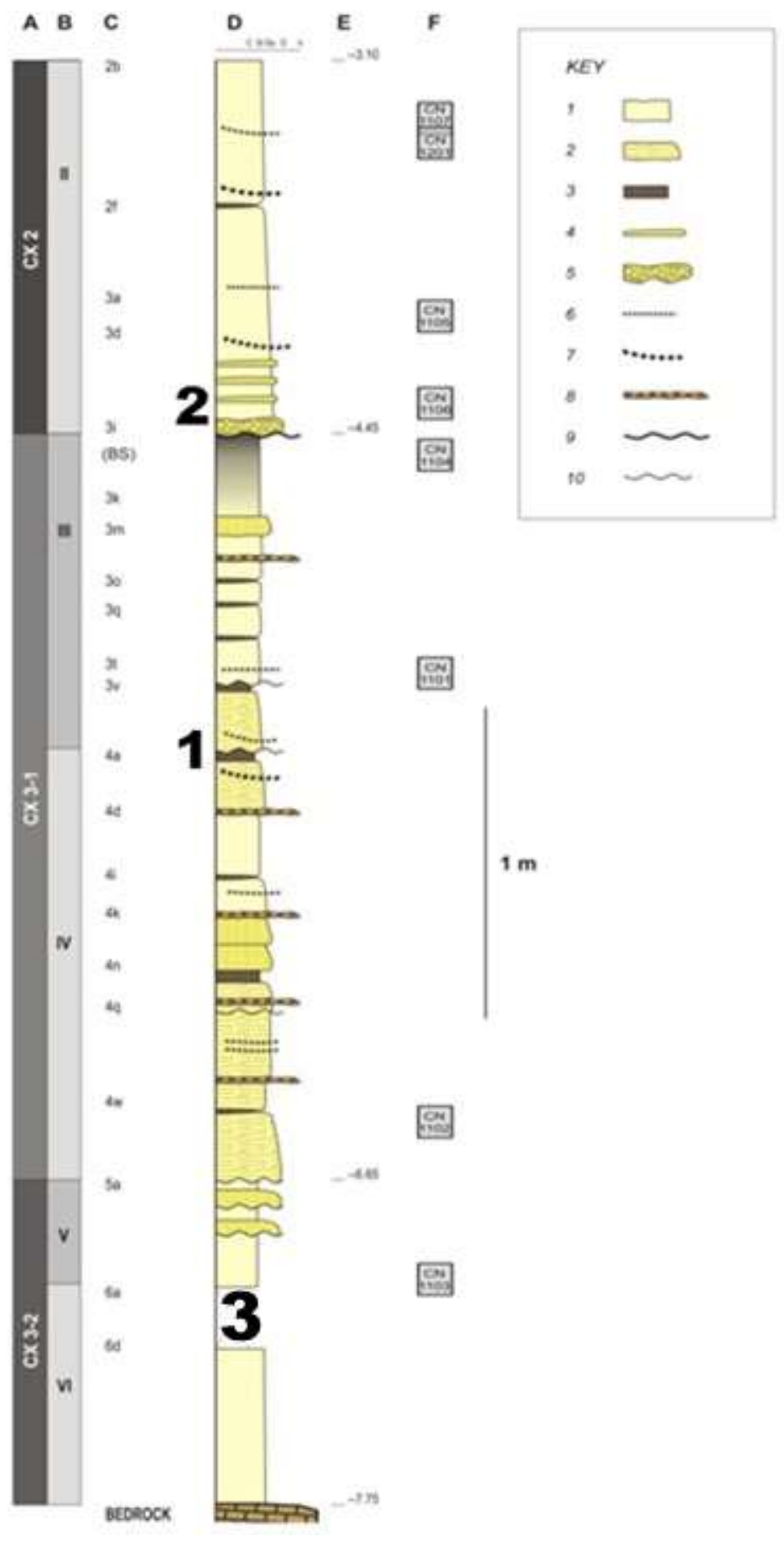

Figure 3. Simplified synoptic stratigraphical column (after Angelucci et al. 2013 and Walker et al. 2016a).

1 The approximate depth from which CN1511 was dated.

2 The approximate depth at which the hand-axe was excavated.

3 Sediments with evidence of combustion (for details, see Angelucci et al. 2013 and Walker et al. 2016b).

A Stratigraphical subdivision based on sedimentological analysis and micromorphology (Angelucci et al. 2013). Key: cx = Complex or Sub-complex).

B Earlier suggested "lithostratigraphical units" (Walker et al. (2006).

$C$ Arbitrary labelling of layers and spits during manual excavation. Key: BS = incipient palaeosol.

$D$ Stratigraphical column. Key: $C=$ clay; $S i=$ silt; $S a=$ sand; $G=$ granules and gravel; $K=$ carbonate crusts or flowstones; stones are not represented in the column.

E Approximate depth below datum point, in metres.

F Stratigraphical position of sedimentary micromorphological samples taken (Angelucci et al. 2013). Key: $1=$ silty sand, massive or poorly laminated; 2 = silty sand with flat lamination or cross-bedding; 3 = silt or clayey silt, massive or with flat lamination; 4 = sand; 5 = gravel; 6 = stone-lines formed of fine granules; 7 = fine lenses of granules to fine gravel; $8=$ calcium carbonate crusts; $9=$ main erosive surface between Complex 2 and Complex 3; $10=$ minor erosive surfaces. 


\section{Methodology}

Since 1990, manual archaeological excavation has been accompanied by washing the excavated sediment over nested 6 $\mathrm{mm}, 4 \mathrm{~mm}$, and $2 \mathrm{~mm}$, stainless steel sieves, thereby maximising recovery of material $>2 \mathrm{~mm}$ in size. Interdisciplinary collaboration has been a priority. Sedimentary components have been the object of palynological, granulometrical, micromorphological, and microstratigraphical studies, as well as geochronological investigations that include magnetostratigraphy, optically stimulated luminescence (OSL), and combined uranium-series (U-series) electron spin resonance (ESR). A deeply lying layer of sediment (ca. $-4.5 \mathrm{~m}$; Figure 3) with undoubted evidence of combustion has been studied using thermoluminescence, Fourier Transform infrared spectroscopy (FTIR), ESR palaeothermometry, X-ray fluorescence (XRF), X-ray diffraction (XRD) and thermogravimetrical analyses, and taphonomical research involving scanning electron microscopy (SEM) and energy-dispersive (EDS) analyses. Palaeontological and taphonomical research has been carried out on excavated remains of birds, reptiles, amphibians, and small and large mammals, and stable-isotope research commenced in 2019. Characterisation of Palaeolithic artefacts includes microscopical studies of use-wear or edge-damage, and comparison by trace-element characterisation with off-site outcrops of rock-forming minerals. Attention has been paid also to the hydrogeological evolutionary relationship between the cave and the Quípar valley during the Pleistocene. For various matters referred to in this paragraph, see: Angelucci et al. 2013; Carrión et al. 2003, 2005; Carrión and Walker 2019; Fernández et al. 2018; López Jiménez et al. 2020; Rhodes et al. 2016; Scott and Gibert 2009; Walker et al. 2004, 2006, 2013, 2016a, 2016b, 2019; Zack et al. 2013; see also Supplementary Information 2.

\section{Chronology}

\section{Magnetostratigraphy}

A magnetostratigraphical study of the sedimentary infilling of the rock-shelter showed predominantly reverse polarity of the deposits (Scott and Gibert 2009). Consequently, the entire sedimentary sequence was correlated to the reverse polarity Matuyama chron (2.58 - $0.772 \mathrm{Ma})$ that preceded the normal Brunhes chron, which provides a minimum age constraint of $0.772 \mathrm{Ma}(\mathrm{Okada}$ et al. 2017; Channell et al., 2020) for the sedimentary sequence at Cueva Negra.

\section{U-series/ESR dating}

An extensive combined U-series/ESR dating study was initiated with the aim of establishing numerical constraints for the sedimentary sequence. Several large-mammal teeth were collected throughout the stratigraphical sequence. While dating analyses are ongoing, we provide the dating results obtained on CN1511, a left maxillary first or second molar tooth of Equus cf. altidens (site inventory number CN-09152) excavated in archaeological layer 4b of "lithostratigraphical unit IV" within the sedimentary stratigraphical Complex 3-1, approximately half-way down the 5-metre-deep sedimentary sequence (Figure 3).

Two samples (A and B) were collected from CN1511 for dating. They were processed following the same analytical procedure as in Stimpson et al (2016). The detailed methodology employed is given in the Supplementary Information. Two sets of ages were calculated. The first used the US-ESR model defined by Grün et al (1988), while the second was based on the CSUSESR model proposed by Grün (2000). The US-ESR model assumes a gradual U-uptake over time following a one-parameter diffusion equation. In contrast, the CSUS-ESR model is based on the assumption that all of the uranium migrated into the sample at a time given by the closed system U-series age. The CSUS-ESR age corresponds to the maximum age that can be derived from a given U-series and ESR data set. Age calculations using the US-ESR and CSUS-ESR models encompass all possible uptake scenarios. If the dose rates derived from the internal uranium concentrations are low, the differences between the US-ESR and CSUS-ESR models are small. This is not the case when the dose rate of a tooth is dominated by the uranium in the various dental tissues. Data inputs and final age results are displayed in Table 1 
Table 1. Data inputs and outputs for the combined US-ESR age calculation. Apparent U-series ages with 2- $\sigma$ errors are also provided in italics. Key: n/a = not applicable; (1) after Grün and Katzenberger-Apel (1994); (2) a 10\% error was assumed; (3) corrected by the long-term water content; Post-Rn equilibrium was assumed in dental tissues and sediment. All errors are given at a 1- $\sigma$ confidence level. The last column presents the merged data set: ESR and U-series data collected for each sample have been combined here into one single data set.

\begin{tabular}{|c|c|c|c|}
\hline SAMPLE & CN1511A & CN1511B & Combined \\
\hline \multicolumn{4}{|l|}{ Enamel } \\
\hline Dose (Gy) & $1631 \pm 136$ & $1601 \pm 84$ & $1615 \pm 84$ \\
\hline $\mathrm{U}(\mathrm{ppm})$ & $1.83 \pm 0.09$ & $1.87 \pm 0.10$ & $1.85 \pm 0.09$ \\
\hline${ }^{234} \mathrm{U} /{ }^{238} \mathrm{U}$ & $1.567 \pm 0.012$ & $1.513 \pm 0.067$ & $1.540 \pm 0.039$ \\
\hline${ }^{230} \mathrm{Th} /{ }^{234} \mathrm{U}$ & $0.890 \pm 0.016$ & $0.932 \pm 0.094$ & $0.911 \pm 0.050$ \\
\hline Alpha Efficiency ${ }^{(1)}$ & $0.13 \pm 0.02$ & $0.13 \pm 0.02$ & $0.13 \pm 0.02$ \\
\hline Water content $(\%)$ & 0 & 0 & 0 \\
\hline Initial enamel thickness $(\mu \mathrm{m})^{(2)}$ & $1203 \pm 120$ & $1229 \pm 123$ & $1216 \pm 122$ \\
\hline \multicolumn{4}{|l|}{ Dentine } \\
\hline $\mathrm{U}(\mathrm{ppm})$ & $98.4 \pm 3.5$ & $96.7 \pm 3.4$ & $97.7 \pm 3.4$ \\
\hline${ }^{234} \mathrm{U} /{ }^{238} \mathrm{U}$ & $1.550 \pm 0.004$ & $1.542 \pm 0.004$ & $1.546 \pm 0.004$ \\
\hline${ }^{230} \mathrm{Th} /{ }^{234} \mathrm{U}$ & $1.048 \pm 0.005$ & $1.055 \pm 0.006$ & $1.052 \pm 0.005$ \\
\hline Water $(\%)$ & $5 \pm 3$ & $5 \pm 3$ & $5 \pm 3$ \\
\hline Removed enamel thickness $(\mu \mathrm{m})^{(2)}$ & $54 \pm 5$ & $67 \pm 7$ & $81 \pm 8$ \\
\hline \multicolumn{4}{|l|}{ Cement } \\
\hline $\mathrm{U}(\mathrm{ppm})$ & $82.1 \pm 2.9$ & $83.6 \pm 2.9$ & $81.9 \pm 2.9$ \\
\hline${ }^{234} \mathrm{U} / 238 \mathrm{U}$ & $1.615 \pm 0.006$ & $1.600 \pm 0.020$ & $1.608 \pm 0.013$ \\
\hline${ }^{230} \mathrm{Th} /{ }^{234} \mathrm{U}$ & $0.985 \pm 0.007$ & $0.989 \pm 0.016$ & $0.987 \pm 0.011$ \\
\hline Apparent $U$-series age $(\mathrm{ka})$ & 247 & 242 & - \\
\hline Water $(\%)$ & $5 \pm 3$ & $5 \pm 3$ & $5 \pm 3$ \\
\hline Removed enamel thickness $(\mu \mathrm{m})^{(2)}$ & $69 \pm 7$ & $94 \pm 9$ & $81 \pm 8$ \\
\hline \multicolumn{4}{|l|}{ Sediment } \\
\hline $\mathrm{U}(\mathrm{ppm})$ & $1.62 \pm 0.09$ & $1.62 \pm 0.09$ & $1.62 \pm 0.09$ \\
\hline Th (ppm) & $2.82 \pm 0.13$ & $2.82 \pm 0.13$ & $2.82 \pm 0.13$ \\
\hline $\mathrm{K}(\%)$ & $0.64 \pm 0.02$ & $0.64 \pm 0.02$ & $0.64 \pm 0.02$ \\
\hline Water $(\%)$ & $15 \pm 5$ & $15 \pm 5$ & $15 \pm 5$ \\
\hline In situ gamma dose rate $\left(\mu \mathrm{Gy} \mathrm{a}^{-1}\right)^{(3)}$ & $363 \pm 21$ & $363 \pm 21$ & $363 \pm 21$ \\
\hline Depth (m) & $15 \pm 5$ & $15 \pm 5$ & $15 \pm 5$ \\
\hline \multicolumn{4}{|l|}{ Combined US-ESR age results } \\
\hline internal dose rate $\left(\mu \mathrm{Gy} \mathrm{a}^{-1}\right)$ & $723 \pm 193$ & $825 \pm 172$ & $773 \pm 158$ \\
\hline beta dose rate, dentine $\left(\mu \mathrm{Gy} \mathrm{a}^{-1}\right)$ & $1690 \pm 451$ & $1631 \pm 340$ & $1667 \pm 341$ \\
\hline beta dose rate, sediment or cement $\left(\mu \mathrm{Gy} \mathrm{a}^{-1}\right)$ & $1178 \pm 313$ & $1131 \pm 235$ & $1142 \pm 233$ \\
\hline Gamma + cosmic dose rate $\left(\mu \mathrm{Gy} \mathrm{a}^{-1}\right)$ & $402 \pm 18$ & $402 \pm 18$ & $402 \pm 18$ \\
\hline Total dose rate $\left(\mu \mathrm{Gy} \mathrm{a}^{-1}\right)$ & $3988 \pm 582$ & $3983 \pm 443$ & $3978 \pm 443$ \\
\hline p enamel & -0.55 & -0.69 & -0.63 \\
\hline p dentine & -0.91 & -0.93 & -0.92 \\
\hline p cement & -0.80 & -0.81 & -0.80 \\
\hline Combined US-ESR age (ka) & $409 \pm 49$ & $402 \pm 40$ & $406 \pm 40$ \\
\hline Combined CSUS-ESR age (ka) & & & $1446 \pm 310$ \\
\hline
\end{tabular}

Following the standard analytical procedure for expectedly "old" (Early Pleistocene or older) samples (e.g., Duval et al. 2012a), laser ablation (LA) U-series analyses were performed first on the tooth cross-sections in order to evaluate their suitability for ESR dating. These analyses were carried out following the procedure described in Grün et al. (2014). LA transects performed across the vestibular side of the tooth showed relatively homogeneous U-series data within each tissue (Figures 4, 5 and S1). Numerical results obtained for each LA spot are given in Supplementary Information Tables S1 and S2. The apparent U-series ages obtained should be regarded as minimum age constraints for the fossils, as uranium uptake may sometimes be delayed significantly after the death of the organism. The enamel tissue in fragments A and B display an apparent age of 188-213 ka, while dentine and cement vary between 308-319 and 242-247 ka, respectively. Consequently, the age results obtained for the dentine tissues suggest that the fossil tooth is at least $320 \mathrm{ka}$. 

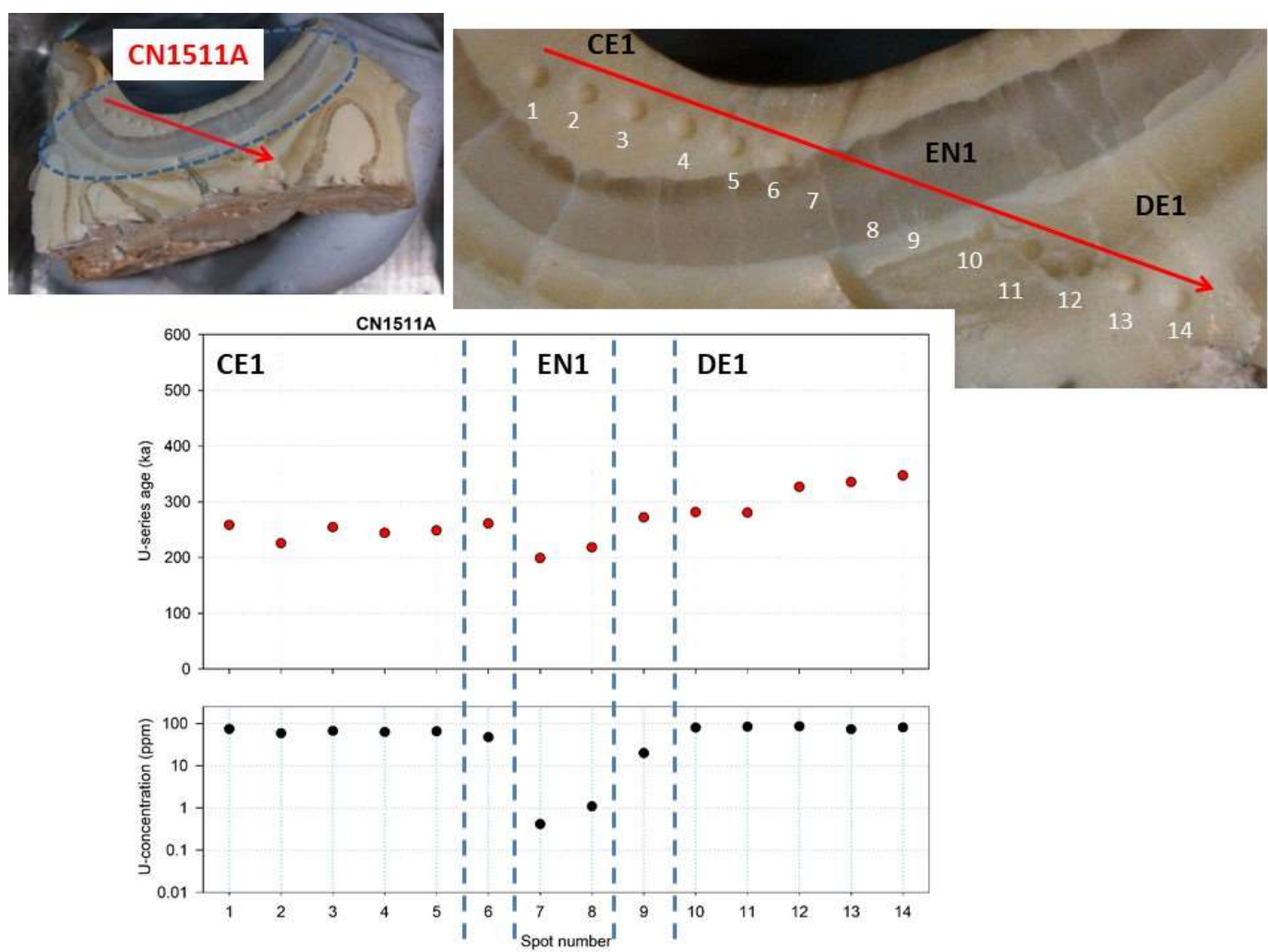

Figure 4: LA-ICPMS U-series results obtained for transect \#1 performed on sample CN1511A. Apparent U-series ages (red circles) and uranium concentration values (black circles) are displayed. The slightly transparent blue domain shows the area sampled for US-ESR dating. Key: $C E=$ cement; $E N=$ enamel; $D E=$ dentine. Numerical values are given in the Supplementary Information 1 (Table S1).

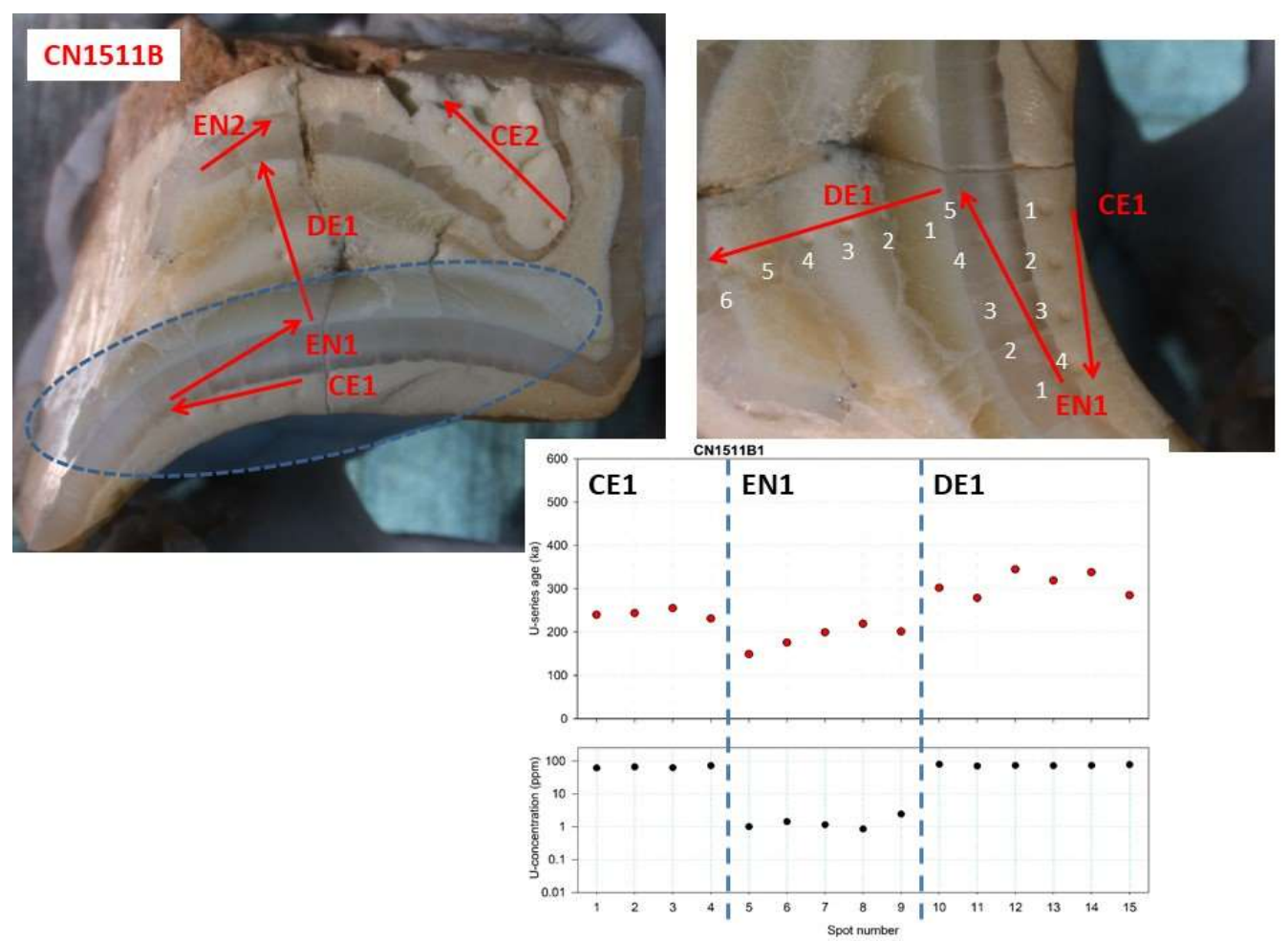

Figure 5: LA-ICPMS U-series results obtained for transect \#1 performed on sample CN1511B. Apparent U-series ages (red circles) and uranium concentration values (black circles) are displayed. The slightly transparent blue domain shows the area sampled for US-ESR dating. Key: $C E=$ cement; $E N=$ enamel; $D E=$ dentine. Numerical values are given in the Supplementary Information 1 (Table S2). 
Combined US-ESR age calculations performed on the two sub-samples of CN1511 returned age estimates of around 400 to $410 \mathrm{ka}$. These close results (within 1.2\%) are due to the highly homogeneous U-series and ESR data collected for each dental tissue of the two samples. Consequently, all these data can be merged into one single data set that may be assumed reasonably to be representative of the whole tooth. The resulting US-ESR and CSUS-ESR calculations yielded age estimates of $406 \pm 40$ and 1446 $\pm 310 \mathrm{ka}$, respectively (Table 1). Typically, US and CSUS models are considered to encompass all possible uptake scenarios; thus, the true age of tooth CN1511 should lie somewhere between these two estimates. Given the ESR and U-series data set collected for CN1511, an Early Pleistocene age estimate can be achieved only if the uranium uptake process in dental tissues has been similar to the conditions described by the CSUS model, i.e., a period of little initial U-uptake followed by a rapid uptake around $300 \mathrm{ka}$. The CSUS-ESR age estimate of $1446 \pm 310 \mathrm{ka}$ is the maximum age constraint for CN1511. This supersedes the preliminary CSUS-ESR age result $890 \pm 136 \mathrm{ka}$ initially indicated in Walker et al. (2019). Its true age lies somewhere between $406 \pm 40$ and $1446 \pm 310 \mathrm{ka}$, which is compatible with the independent biochronological and magnetostratigraphical evidence, but also shows the limited value of ESR age estimates on teeth where the total dose rate is dominated by the various U sources in the dental tissues. More fossil herbivore teeth from Cueva Negra are being dated using the same procedure. They should contribute to refine this preliminary ESR chronology. Meanwhile, additional age control is available from the combination of palaeomagnetism and biochronology. A more extensive discussion around the reliability of the dating results and their sensitivity to different sources of uncertainty can be found in the Supplementary Information 1.

\section{$\underline{\text { Palaeontology Results }}$}

\section{Small vertebrates}

Cueva Negra has provided abundant small mammal remains of which 2,500 teeth excavated in sedimentary complexes 2 and 3 have undergone detailed taxonomical and metrical analyses (López Jiménez et al. 2020); specimens with the same taxonomical species designation are very similar in the two complexes. Well represented in the rich Cueva Negra assemblage of small mammals (López Jiménez et al. 2020) are Cricetulus (Allocricetus) bursae, Eliomys quercinus, Apodemus cf. sylvaticus, Sciurus vulgaris, Oryctolagus cf. giberti, Lepus sp., Prolagus calpensis, Erinaceus europaeus, Crocidura kornfeldi, Neomys sp., Sorex sp., Myotis cf. myotis; latterly, Hystrix has been identified also. Absent are some taxa (e.g., Castillomys rivas) identified in Jaramillo sub-chron sediments in Murcia at Quibas-Sima near Fortuna (Piñero et al., 2020). Particularly significant at Cueva Negra are the lower first molar teeth of the extinct Arvicoline voles Victoriamys chalinei $(\mathrm{n}=155)$, Mimomys savini $(\mathrm{n}=34)$, Iberomys huescarensis $(\mathrm{n}=191)$, Pliomys episcopalis $(\mathrm{n}=11)$, Stenocranius gregaloides $(\mathrm{n}=3)$, and Terricola arvalidens $(\mathrm{n}=2)$. Mimomys savini was a characteristic Biharian species (Fejfar et al. 1998) that existed in Europe from middle Early Pleistocene to early Middle Pleistocene times (ca. 1.8 - ca. 0.6 Ma). Victoriamys chalinei, Iberomys huescarensis, Stenocranius gregaloides, and Terricola arvalidens are well-known in Spain during the late Early Pleistocene (Cuenca-Bescós et al. 2010), when Terricola and Stenocranius arose (Van Kolfschoten and Markova 2005), whilst the last appearances in Spain of Victoriamys chalinei, Iberomys huescarensis, Stenocranius gregaloides, Terricola arvalidens and Pliomys episcopalis are during the early Middle Pleistocene (Agustí et al. 2015; Cuenca-Bescós et al. 2010).

The association at Cueva Negra of Mimomys savini, Iberomys huescarensis and Stenocranius gregaloides has parallels in northern Spain in layers TD3-TD8 at Atapuerca (Cuenca Bescós et al. 1995, 1999), and layers D5 at Cal Guardiola and Vallparadís EVT7, at Terrassa in Catalonia (Minwer-Barakat et al. 2011); at Atapuerca the Allophaiomys (Victoriamys) chalinei biozone falls between ca. 0.9 and ca. 0.6 Ma (Cuenca-Bescós et al. 2010). In southeastern Spain, Cueva Victoria near Cartagena in Murcia has given its name to the many specimens of Victoriamys chalinei (Martin 2015) from sediments for which ${ }^{230} \mathrm{Th} / \mathrm{U}$ and palaemagnetic analyses of flowstone imply an age of ca. 0.9 - 0.85 Ma (Budsky et al. 2015; Gibert and Scott, 2015; Gibert et al. 2016 In Granada, Iberomys huescarensis and Mimomys savini come from the Huéscar 1 site (Mazo et al. 1985; Agustí et al. 2010). Extended-range Luminescence dating using a suite of different cutting-edge approaches (OSL dating of quartz 'supergrains', multi-grain and singlegrain thermally-transferred (TT) OSL of quartz and post-infrared infrared (pIR-IR) stimulated luminescence of K-feldspars) yielded internally consistent ages of ca. $0.45 \mathrm{Ma}$ (Demuro et al. 2015) for the site, i.e. much younger than the pre-Brunhes chronology ( $>0.77 \mathrm{Ma}$ ) derived earlier by magnetostratigraphical correlation with the nearby locality of Puerto Lobo (Gibert et al. 2007). Additionnally, biochronological inference based on the abudant presence of Mimomys and absence of Arvicola suggests a time no later than the initial Middle Pleistocene (0.77 - ca.0.6 Ma). The I. huescarensis biozone defined in the Granada Guadix-Baza Basin (Agustí et al. 2015) between 1.07 and ca. $0.8 \mathrm{Ma}$ (perhaps reaching a slightly younger age), and the following T. arvalidens biozone there, after the Matuyama-Brunhes boundary, afford an appropriate chronological context for Cueva Negra which has provided two T. arvalidens teeth and lies $50 \mathrm{~km}$ away from the northern rim of the Guadix-Baza Basin. In western Andalusia, in Cadiz, the late Early Pleistocene site of El Chaparral offers a range of arvicoline species comparable to those at Cueva Negra (López-García et al. 2012).

The initial study of excavated bones of 66 bird taxa (by avian palaeontologist A. Eastham in Walker et al. 2004, 2006) is being extended currently (2019-2020) by A. Rufà Bonache. Hermann's tortoise is represented by abundant remains identified as Testudo (Eurotestudo) hermanni (X. Murelaga Bereicua, pers. comm., 2007-2008; and see comment in Morales \& Sanchis 2009, 1156; for definition of Eurotestudo see de Lapparent de Broin et al., 2006a,b,c). Latterly, following Bour and Ohler (2008) it has been argued by Pérez-Garcia et al. (2015) that Hermann's tortoise at Cueva Victoria in Murcia should be classified as Chersinne hermanni, which may have consequences for further investigation of the Cueva Negra specimens, given that both sites are of similar age. Intriguing taphonomical research suggests that early humans consumed tortoise before $1 \mathrm{Ma}$ at the Atapuerca Sima del Elefante (Blasco et al. 2011). Remains of reptiles and amphibians corresponding to thirteen taxa, all present in Spain today, indicate summer and winter temepratures similar to those nowadays at Cueva Negra though precipitation was greater (H-A. Blain, pers. comm., 
unpublished report October 2019). Compilation of the complete faunal list is at an advanced stage of progress. The small vertebrates are consistent with palynological evidence of benign environmental conditions and overlapping biotopes including temperate gallery-woodland with deciduous trees identified by palynology (Carrión et al. 2003, 2005; Carrión and Walker 2019). Nearby presence of a lake is indicated by eight species of waterfowl, including diving pochards that reflect the existence of an erstwhile lake near the cave (of the eight, only the mallard exists in the neighbourhood today). The faunal taxa identified at the site indicate the presence of other biotopes nearby, namely, open mixed woodland, open grassland and moorland, and craggy mountainsides. The biodiversity manifested by the excavated remains is undoubted evidence of the importance of the habitat that the rock-shelter afforded to several species that frequented it. Flora and fauna are appropriate for a warm marine isotope stage, plausibly MIS21 (0.87 - $0.81 \mathrm{Ma}$ ), though other contenders could be MIS 25 (after ca. $1 \mathrm{Ma}$; cf., Lisiecki and Raymo 2005) or the somewhat cooler MIS23 (ca. $0.9 \mathrm{Ma}$ ). These are not, however, the only possibilities, because, during glacial periods, the Iberian Peninsula was often a refugium for "interglacial" fauna ("glacial species" of such large mammals as reindeer, woolly rhinoceros, and mammoths, first appeared in Spain perhaps as late as MIS 6), moreover, before MIS 16, glaciations seem to have been less severe, therefore the presence of temperate-adapted fauna need not altogether rule out a glacial period.

\section{Large mammals}

Revision of remains of the large mammals excavated at Cueva Negra demonstrates presence of Macaca sp., Proboscidea indet., Ursus sp., Mustelidae, Crocuta, Lynx sp., Equus cf. altidens, Stephanorhinus etruscus, Sus scrofa, Capreolus, Dama cf. vallonnetensis, Megaloceros novocarthaginiensis, Caprini indet., and Bison sp. There are some differences with previously published faunal lists (e.g., Walker et al. 2010), where Equus cf. suessenbornensis, Bos primigenius, Cervus cf. elaphus and Capra cf. ibex were included; as explained elsewhere (Walker et al. 2016a) small fragments of large mammals, recovered during the 1981 prospection, when the assemblage was regarded as early Late or late Middle Pleistocene in age, understandably were assigned provisional taxonomical identifications appropriate for that period by J. Estévez Escalera, which continued to influence excavators after 1990 until much earlier extinct taxa began to be identified by J. Gibert i Clols whose death in 2007 unfortunately delayed the process of taxonomical revision. None of the available caprine remains favours an assignation to Capra over Hemitragus. The only horn core belongs to Bison and bovine dental remains also fit that taxon. Large deer and horse are discussed below. Some specimens of biochronological relevance are discussed here. Detailed analysis is in progress of the numerous large-mammal fossils. A preliminary conclusion is that Crocuta and Bison imply an open landscape away from the river valley, whilst deer, bear and boar point to more closed conditions, probably in the river valley. Equus cf. altidens suggests an open, dry landscape nearby. The caprine and perhaps the macaque suggest the rocky environment of the surrounding steep valley-sides. The deer, boar and macaque imply temperate environments, either during an interglacial period or maybe even in a glacial one with limited effect in terms of temperature at this latitude.

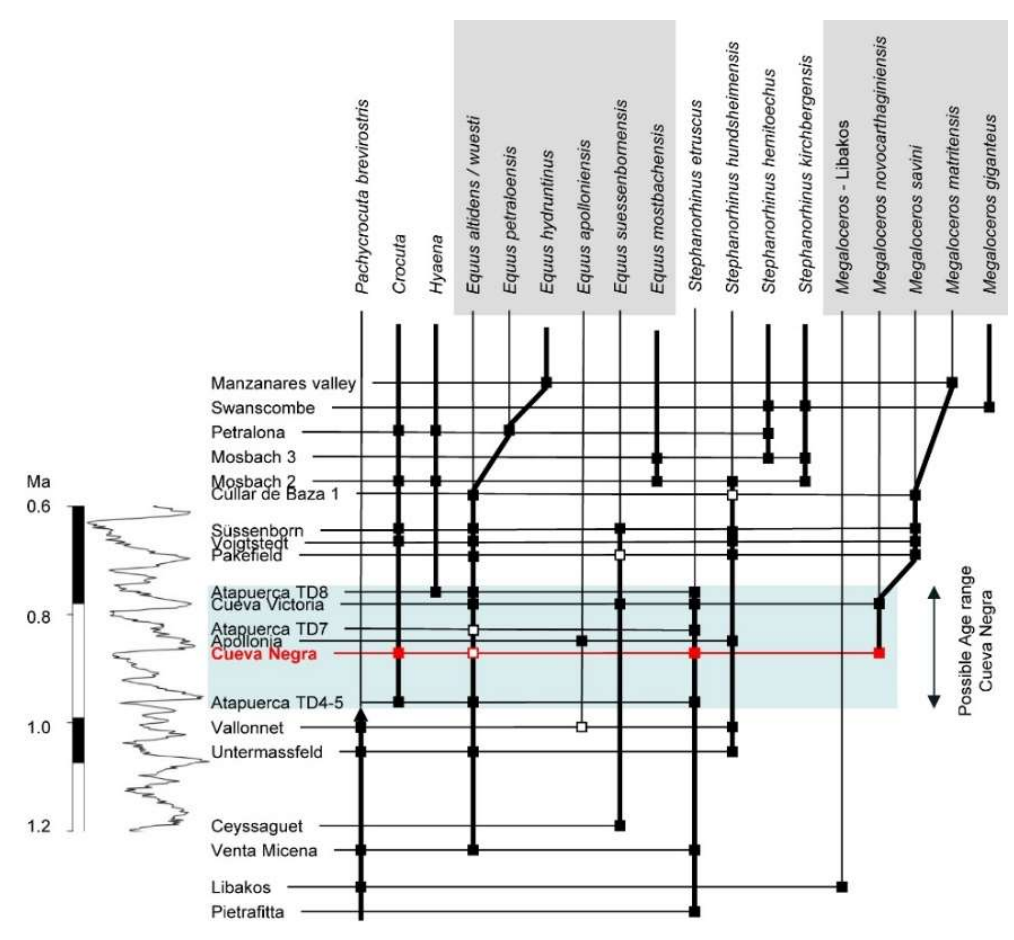

Figure 6. Stratigraphical distribution of taxa discussed in the text (after Van der Made et al. 2017). Solid squares indicate presence, open squares indicate possible presence or presence of a similar species that is not exactly known (conventionally indicated by: cf., aff., ?, sp.). Localities older than 1.2 Ma and younger than 0.6 Ma shown in approximate order of age (old below, young top). 


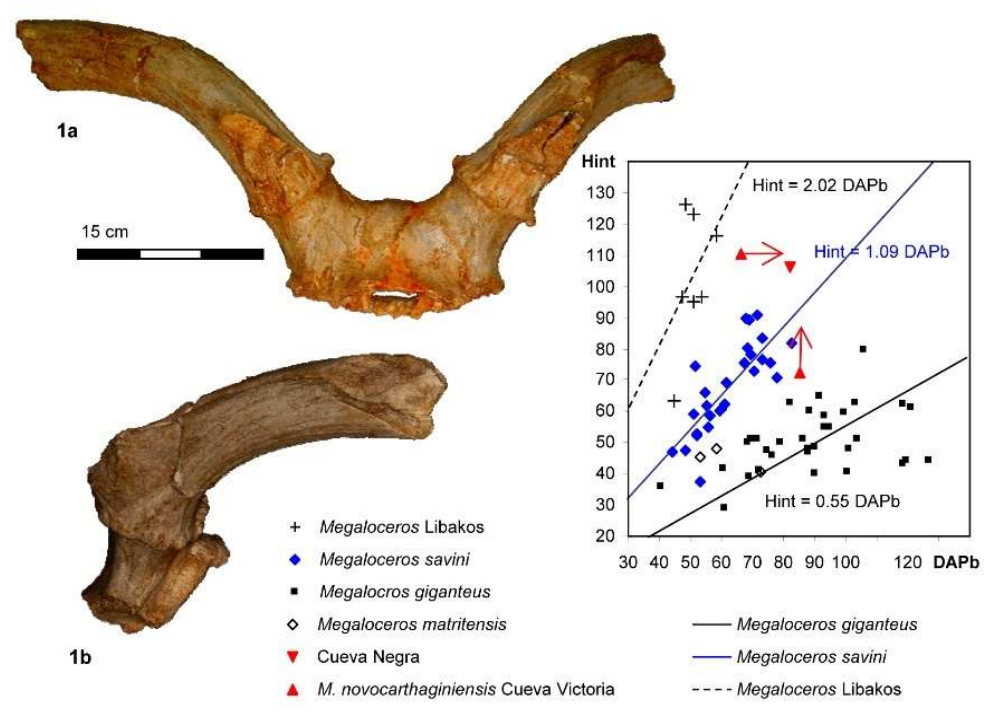

Figure 7. Megaloceros novocarthaginiensis from Cueva Negra (squares C2b,C2c; layers 3k,3l): skull fragment with bases of right and left antlers, in (1a) frontal and (1b) left lateral views. Right: Bivariate diagram comparing DAPb and Hext of the antlers of various species of Megaloceros. $\mathrm{DAPb}=$ antero-posterior diameter of the antler, taken just above the burr. Hext $=$ distance from just below the burr to the bifurcation between the brow tine and main beam, measured on the lateral side. Measurements as by Van der Made and Tong (2008, fig. 4). Arrows indicate approximate measurements. Specimens: Megaloceros sp. from Libakos (material studied in TUC - see Supplementary Information 2 for acronyms of collections); M. novocarthginiensis from Cueva Victoria (IPS, MAC; Van der Made 2015a) and Cueva Negra (MAM); M. savini from Ponte Galeria (MPUR), Süssenborn (IQW) and Cúllar de Baza 1 (MNCN); M. matritensis from Transfesa (MNCN; Van der Made 2017) and Arenero los Pinos / km 5 carretera de San Martin de la Vega - both in terraces of the Manzanares in Madrid (MSI; Van der Made 2017); M. giganteus from Swanscombe (NHM), Steinheim (SMNS), Neumark Nord (LVH), Bisnik Cave (ZPALUWr), Late Pleistocene Rhine sediments (SMNS; IPRFWUB), Botro Maspino (IGF), and "Altai” (IAMM).

\section{Giant deer Megaloceros novocarthaginiensis}

A species of large deer is represented by a skull fragment, teeth and dental and bone fragments (some of these remains previously had been regarded as Cervus). What remains of the brow tines shows that they were palmate (Figure 7/1). European large deer form two groups (Azzaroli 1952). The genus Megaloceros has palmate brow-tines, whilst various other genera have brow-tines that are cylindrical in cross-section.

The species of Megaloceros includes M. giganteus, M. novocarthaginiensis, M. savini and M. matritensis. These differ in the morphology and proportions of their antlers, mandible, dentition, and the bones of the skeleton, as well as in dental enamel thickness and absolute size (Van der Made and Tong 2008; Van der Made 2015a, 2017). The adults of Megaloceros giganteus have palmate brow-tines that dip laterally, whilst in the other species they dip medially (Van der Made and Tong 2008). In the large deer from Cueva Negra the plane of palmation dips medially, in contrast to $M$. giganteus. The antero-posterior diameter of the antler above the burr (DAPb) and the height of the bifurcation between brow-tine and main beam (Hext) are indicated in the bivariate diagram (Figure 7) where different species of Megaloceros occupy separate fields in terms of differential proportions and size of their antlers. Megaloceros novocarthaginiensis is represented by two specimens that show some damage, hence real values were slightly larger than those measured (see arrows in Figure 7). The Cueva Negra antler affords high values for both Hext and DAPb, as in M. novocarthaginiensis. General size, as indicated by dentition, accords with this identification.

This identification has biochronological implications. The giant deer M. novocarthaginiensis, M. savini and M. matritensis share features, which are interpreted as shared derived features, including: a palmate brow-tine that dips medially, a middle tine, and moderately robust mandibles (Van der Made 2015a 2017). These three species show, in this order, a cline in decreasing size and the progressive development of morphological features, including a lowering of the origin of the brow-tine, increased relative premolar size (particularly $\mathrm{P}_{2}$ ), and an increase in enamel thickness. Megaloceros novocarthaginiensis is described at Cueva Victoria near Cartagena in Murcia (Van der Made 2015a). The age of Cueva Victoria was interpreted initially as ca. 1.2 - 1.4 Ma (Agustí et al. 1987), though subsequent palaeomagnetic and ${ }^{230} \mathrm{Th} / \mathrm{U}$ analyses of flowstones point towards ca. 0.9 - $0.85 \mathrm{Ma}$, possibly correlated to MIS22 ( Gibert et al. 2016 and references therein). Megaloceros savini is believed to be of early Middle Pleistocene age and is known from a series of localities in the Cromer Forest Bed (U.K.), including Pakefield (Lister 1993) as well as from Voigtstedt and Süssenborn in Germany (Kahlke 1965, 1969). Pakefied is probably the oldest of these localities and is correlated to MIS17, ca. 0.68 Ma, or MIS19, ca. $0.75 \mathrm{Ma}$ (Parfitt et al. 2005). Megaloceros matritensis is known from 10 localities or levels, which are all younger than all known localities with M. savini. These three species form an evolutionary lineage, because: 1) they share derived features, showing them to be closely related; 2) they have different ages; 3 ) there is a gradual change in size and morphology from the older to the younger species (Van der Made 2015a, 2017). Being ancestral to M. savini, presence of Megaloceros novocarthaginiensis at Cueva Negra indicates an older age than that of any site with M. savini (Figures 6 and 7). Even though the earliest $M$. savini might not be from MIS19, but instead from MIS17, some time is needed in order to evolve a different morphology and size from $M$. novocarthaginiensis, suggesting a final Early Pleistocene age for Cueva Negra. 

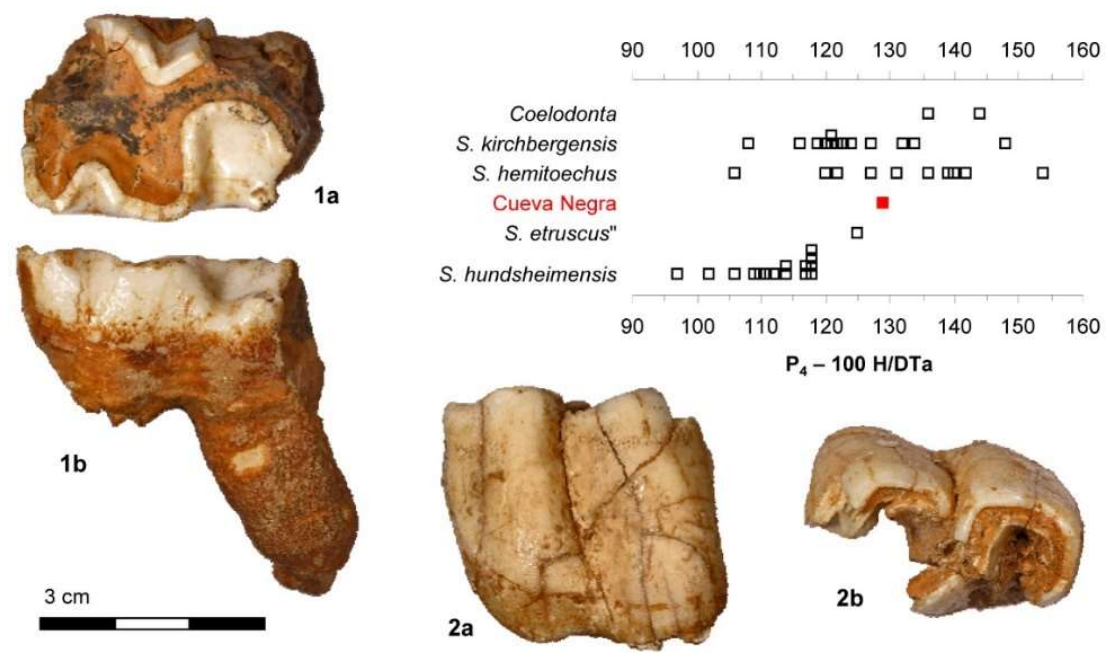

Figure 8. Stephanorhinus etruscus from Cueva Negra: (1) right $M_{3}$ in (1a) occlusal and (1b) lingual views (square C2a, layer 6e; $I D=H 03-016)$; and (2) left $P_{4}$ in (2a) buccal and (2b) occlusal views (ID=H00-015). Top right: Comparison of the hypsodonty indices of this $P_{4}$ with various species of European Pleistocene rhinoceroses. Specimens: S. hundsheimensis from West Runton (NHM), Voigtstedt (IQW), Süssenborn (IQW), Mosbach (NMM); "small S. etruscus" from Atapuerca TD-base (MB), Cueva Negra (UMu); S. hemitoechus from Bilzingsleben (FBFSUJ), Ehringsdorf (IQW) and Late Pleistocene Rhine sediments (NMM); S. kirchbergensis from: Mosbach (NMM), Bilzingsleben (FBFSUJ), Ehringsdorf (IQW) and Late Pleistocene Rhine sediments (NMM); Coelodonta from Late Pleistocene Rhine sediments (NMM). The hypsodonty index is $100 \mathrm{H} / \mathrm{DTa}$, where $\mathrm{H}=$ crown height and DTa $=$ transverse diameter of the anterior lobe (measurements as in Van der Made 2010, Figure 5/3).

\section{Rhinoceros Stephanorhius etruscus}

Cueva Negra has provided over 30 Rhinocerotid fossils, nearly all of them tooth fragments. The enamel of the teeth is smooth as in Stephanorhinus, unlike the rugose enamel of Coelodonta. The four European Stephanorhinus species differ in size, tooth proportions, and morphology of the skull, teeth and postcranial skeleton. Whereas Stephanorhinus kirchbergensis was a large species, the Cueva Negra teeth are more similar in size to those of the remaining species. These species differ in hypsodonty, which is well seen in the molars, of which there are bigger samples, but the pattern is similar in the premolars. $\mathrm{A}_{3}$ and $\mathrm{P}_{4}$ are from the same tooth row and both are unworn at the junction of the anterior wing of the hypoconid and the metalophid, which is where crown height is measured (Van der Made 2010). The Cueva Negra $\mathrm{P}_{4}$ (Figure 8) is more hypsodont than its homologue in $S$. hundsheimensis. The $\mathrm{M}_{3}$ has a posterior valley, which in lingual view is $\mathrm{U}$-shaped, whilst that of $S$. hemitoechus has a V-shape. Therefore, the rhinoceros from Cueva Negra is not $S$. hemitoechus. The teeth from Cueva Negra are most similar to those of $S$. etruscus. The later samples of S. etruscus have been considered, variously, to be small and more closely related to $S$. hundsheimensis (Mazza et al. 1993), to belong to that species (Lacombat 2006), or to be more closely related or identical to S. etruscus (Cerdeño 1993; Van der Made 1999, 2010, 2015b; Pandolfi et al. 2017). The material from Cueva Negra belongs to this small rhinoceros.

The late appearances of S. etruscus (Pandolfi et al. 2017) at Cueva Victoria (Van der Made 2015b) and Atapuerca TD4-7 (Van der Made 1999), are both below the Matuyama-Brunhes boundary and above the Jaramillo sub-chron (Gibert et al. 2016; Parés et al. 2013, 2018; Álvarez-Posada et al. 2018). Palaeomagnetic and ${ }^{230} \mathrm{Th} / \mathrm{U}$ analyses of flowstones imply an MIS22 age ca. 0.9 $0.85 \mathrm{Ma}$ for the Cueva Victoria faunal assemblage (Budsky et al. 2015; Gibert and Scott, 2015; Gibert et al. 2016). The Atapuerca Gran Dolina TD4-7 levels have been dated by a multi-technique dating approach including magnetostratigraphy, US-ESR, TL, pIRIR and TT-OSL methods (Álvarez-Posada et al. 2018; Arnold et al. 2014; Berger et al. 2008, Falguères et al. 1999). More recently, direct combined U-series/ESR dating of a Homo antecessor tooth from TD6 provided a constrained age of $0.95-0.77$ Ma (Duval et al. 2018).The only known Middle Pleistocene occurrence of S. etruscus is at Atapuerca TD8 (Van der Made et al. 2017) immediately above the Matuyama-Brunhes boundary (Parés et al. 2013) and dated variously to around $0.6 \mathrm{Ma}$ (Falguères et al., 1999) and 0.816 $\pm 0.140 \mathrm{Ma}$ (Berger et al. 2008). The site was correlated to MIS19 on the basis of these methods and fauna (Van der Made et al. 2017). The presence of a small rhinoceros, identified as S. etruscus, suggests an age for Cueva Negra, not later than TD8 or MIS19. 


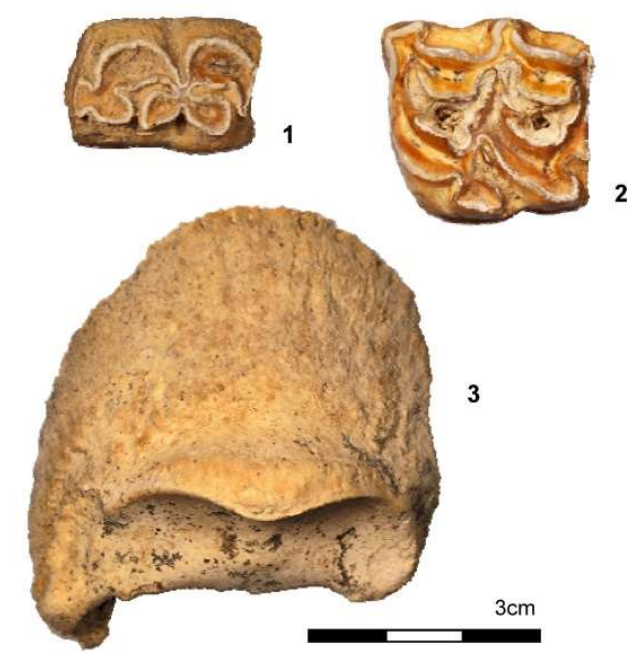

Figure 9. Equus $c f$. altidens specimens from Cueva Negra: (1) left $M_{1 / 2}(I D=H 93-007)$ in occlusal view; (2) left $P^{3 / 4}$ (ID=H05-021) in occlusal view; (3) third phalanx in dorsal view.

\section{Horse Equus cf. altidens}

Many horse fossils, mostly teeth, were recovered from Cueva Negra. The lower cheek teeth have V-shaped linguaflexids (or entoflexids; Figure 9/1) and the upper cheek teeth have short protocones (Figure 9/2), as in the stenonid horses and unlike the caballoid horses (Forstén 1988). Therefore, they do not represent a caballoid horse such as E. caballus. The stenonid horse E. suessenbornensis is very large and has many plications in the upper cheek teeth (Musil 1969), whereas Cueva Negra horse teeth are smaller with few plications (Fgure 9/2). Another large horse was E. apolloniensis (Koufos et al. 1997). The remaining stenonid horses of the late Early to Late Pleistocene of Europe are small, present fewer plications in the upper cheek teeth, and have slender metapodials. Horses of this group from the latest Early Pleistocene were slightly larger than the earlier and later E. altidens and currently are assigned to other species, such as E. wuesti (Musil 2001), though the exact relationship with E. altidens is unclear (Van der Made et al. 2017). From the earliest Middle Pleistocene onwards, these horses plausibly formed an evolutionary linage $E$. altidens - E. petralonensis - E. hydruntinus (Van der Made et al. 2017), characterised by decrease in postcranial size. This is less clear in the teeth, no doubt because their very hypsodont teeth show a wide range of variation. At Cueva Negra the teeth fall within an overlapping range between E. altidens and E. petralonensis (Musil 1969; Tsoukala 1989), though sparsity of postcranial remains precludes further precision. The horse fossils from Cueva Negra are assigned to Equus cf. altidens.

Caballoid horses appeared first with E. mosbachensis and maybe E. ferus (or E. ferus torralbae) ca. $0.6-0.5$ Ma and replaced the large stenonid horse E. suessenbornensis. The smaller E. altidens survived this event and coexisted with the caballoid horses, giving rise to the smaller E. petralonensis (Van der Made et al. 2017). The horse from Cueva Negra belongs to one of those species. This imprecision limits the biochronological value. However, a left maxillary $\mathrm{M}^{1 / 2}$ of Equus cf. altidens from Cueva Negra $(\mathrm{ID}=\mathrm{CN}-09152)$ was used for ESR dating (CN1511) (Figures 1, 4 and 5).

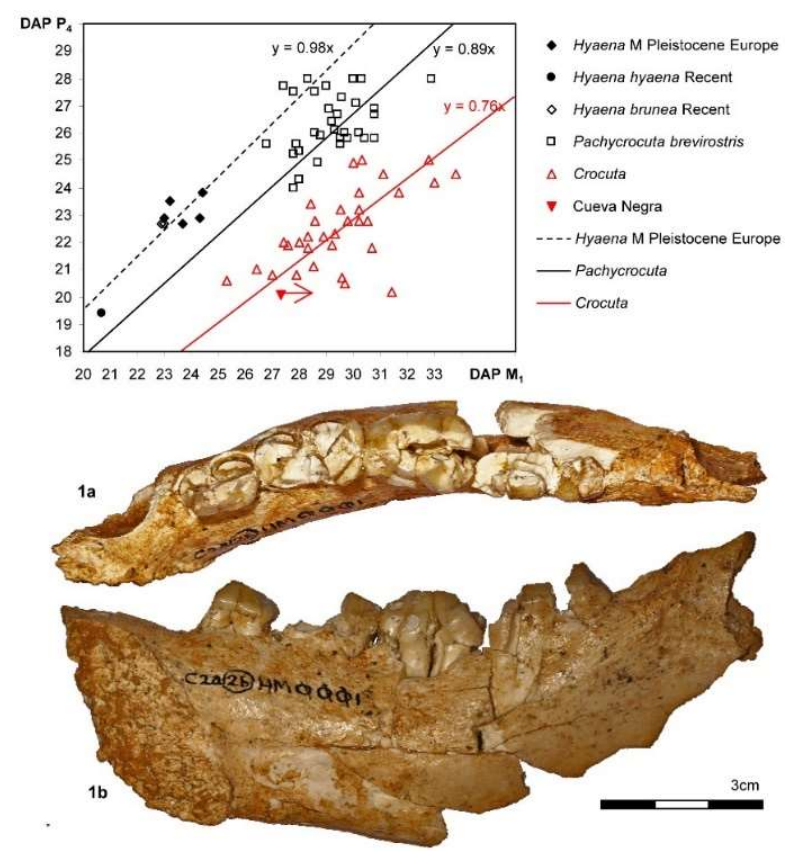

Figure 10. Crocuta from Cueva Negra (squares C2a/2b, ID=HM0001): right mandible with $P_{2}-M_{1}$, in (1a) occlusal and (1b) lingual views. Bivariate diagram comparing antero-posterior diameters $(D A P)$ of $M_{1}$ and $P_{4}$ of different Hyaenidae. Specimens: Hyaena 
hyaena from Khorramabad (Iran); recent Hyaena brunnea (NBC); Middle Pleistocene Hyaena sp. from Atapuerca TD8 (IPHES), Mosbach (NMM), St. Estève and Lunel Viel (Bonifay 1971); Pachycrocuta brevirostris from Valdarno, Sainzelles, Kromdraai, Venta Micena, Untermassfeld, Vallonnet, Gombaszög, Incarcal I, Lakhuti, Zasuhino, Stránská Skála, Manastirec, Siwaliks Volga R, and Zhoukoudian (data from Turner and Antón 1996); Crocuta from Tighennif (MNHN), Lunel Viel, Châtillon-St.-Jean, Grotte de la Baume Longue and Rigabe (Bonifay 1971), and Abric Romani (MMPC), as well as from Cueva Negra.

\section{Spotted hyaena Crocuta}

A hyaena mandible (Figure 10) came from disturbed sediment that filled a small pit dug into the Pleistocene sediments after the Spanish Civil War. The specimen likely came from the upper part of the sediments of Cueva Negra (in 2019 more hyaenid fossils were excavated in them). Its teeth are damaged, but its $\mathrm{P}_{4}$ length is measurable. Originally, its $\mathrm{M}_{1}$ length exceeded that of the existing tooth fragment which nevertheless is as long as in Crocuta. The genus Crocuta has elongated $\mathrm{M}_{1}$ that are longer with respect both to their width and to the length of the other cheek teeth than was the case in Hyaena and Pachycrocuta; the specimen from Cueva Negra clusters with Crocuta (Figure 10).

Crocuta was common in western Europe and the oldest site with certain presence of Crocuta is Atapuerca Trinchera Dolina TD4 (García and Arsuaga 2001; Figure 3), shown by palaeomagnetism to be slightly younger than the Jaramillo sub-chron (ÁlvarezPosada et al. 2018; Parés et al. 2018). The presence of this taxon, probably at the top of the sequence of Cueva Negra, suggests an age not older than TD4.

\section{Bear Ursus sp.}

Isolated anterior teeth, disconcertingly similar in size and shape to some isolated first and second mandibular Neanderthal incisors published from the Grotte d'Hortus (de Lumley-Woodyear 1973), were found in superficial loose sediment and compared to Neanderthal examples (Walker et al. 2006) at a time when the Cueva Negra deposits were considered to be no earlier than the late Middle Pleistocene, but acceptance of their greater antiquity now renders untenable any such comparison. Subsequent morphological considerations imply that those specimens very likely belong to Ursus sp., in support of which a characteristically ursid lateral (third) incisor was identified during the 2019 excavation in the uppermost sediments of a hitherto unexcavated area at the rear of the cave; levels excavated previously at the site had provided one or two bone fragments tentatively regarded as ursid also.

\section{$\underline{\text { Discussion }}$}

The late Early Pleistocene age of the Cueva Negra assemblage is supported by presence of the giant cervid Megaloceros novocarthaginiensis in sediments that magnetostratigraphy assigns to the Matuyama chron. Megaloceros novocarthaginiensis is known only from the late Early Pleistocene. The rhinoceros Stephanorhinus etruscus is an Early Pleistocene taxon that is recorded at only one early Middle Pleistocene site. Palaeontological considerations of Cueva Negra imply a time after the Jaramillo subchron (1.07 - 0.99 Ma: Channell et al., 2020). Consequently, the sedimentary sequence must have been laid down between the end $(0.99 \mathrm{Ma})$ of that sub-chron and the Matuyama-Brunhes boundary at $0.772 \mathrm{Ma}$. The palaeontological and magnetostratigraphical constraints of $0.99-0.772 \mathrm{Ma}$ are compatible with the age range given by the US-ESR and CSUS-ESR age results of $1446 \pm 310$ ka and $406 \pm 40 \mathrm{ka}$ (i.e., $1.45 \pm 0.31 \mathrm{Ma}$ and $0.41 \pm 0.04 \mathrm{Ma}$ ), respectively.

At the rear of the cave, at a depth of $4.5 \mathrm{~m}$ (Figure 3), well below the level dated by ESR sample CN1511, undoubted evidence of combustion has been exposed to date over a $4 \mathrm{~m}^{2}$ area in a layer of ashy sediment containing diverse, thermally-affected elements including bone fragments, chert (flint) nodules, and struck flakes (Walker et al. 2016b). Chert had been heated to $>400$ $450^{\circ} \mathrm{C}$ according to TLand ESR palaeothermometry determinations, though higher temperatures are implied by $>100$ heat-shattered chert spalls $<2 \mathrm{~mm}$ in size, and by both low- and high-power microscopy of thermally-altered chert (Walker et al. 2016b). Bone had been heated to $>400-450^{\circ} \mathrm{C}$ according to FTIR. The effects of combustion are supported by: 1) SEM-EDS, 2) contrasts with bones in overlying layers involving colorimetrical and taphonomical analyses of small-mammal remains (Rhodes et al. 2016; Walker et al. 2016b), and 3) the significant component of hydroxyapatite in the combusted sediment in contrast to overlying and underlying sediments, the chemical and mineral composition of all of which have been compared using thermogravimetrical analysis with mass spectrometry and granulometry by laser diffraction, and XRF and XRD methods (Walker et al. 2016b). The deeply-lying combustion feature is of great interest because the high temperature that was reached suggests fire was tended deliberately at the rear of the rock-shelter (Walker et al. 2016b). It is plausible, therefore, that at Cueva Negra fire was tended inside the cave, causing temperatures above those usually reached by bush fires outdoors. Absence of hearth-stones or a fire-pit implies uncontrolled heat. However, unless provision of suitable fuel had been made inside the cave, it is unlikely that sparks from a bush fire outside could have set alight brushwood, by chance lying inside, such as to produce a roaring fire. Maybe a bush fire outside left embers that were taken inside, where fire could be tended away from rain or wind. Plausibly, whoever frequented the cave was less afraid of fires than were animals fleeing from them. A blazing fire tended in a cave could fulfil several purposes: keeping fierce animals away, providing warmth and light, and roasting food in its embers. Fire implies human cognitive capability at Cueva Negra comparable to that at other sites with combustion and hand-axe remains such as Wonderwerk Cave ca. 1 Ma in South Africa (Berna et al. 2012) and Gesher Benoth Ya'aqov ca. 0.78 Ma in Israel (Alperson-Afil 2012; Alperson-Afil and Goren-Inbar 2020; Goren-Inbar 2004).

The Cueva Negra artefact assemblage demonstrates presence of technological diversity and utilisation of a variety of raw materials. A bifacially flaked hand-axe on limestone was excavated (in "lithostratigraphical unit $\mathrm{II}_{\mathrm{ii}}$ ", spit 3h: Figure 3) approximately one metre above the dated equid tooth $\mathrm{CN}-1511$. It was fashioned by removal of no more than 30 flakes from a hard limestone 
cobble that still bears some cortex (Walker et al. 2006, Figures 8 and 9; 2013, Figure 6; 2016a, Figure 1). It had lost its tip in antiquity; its edges are sharp and fresh, neither rolled nor water-worn, and its horizontal transverse cross-section shows an S-twist (which is seen often in "Acheulian" hand-axes). A chopping tool with sharp, fresh edges, formed by unidirectional removal of 15 flakes from a flat limestone cobble, was excavated in the same layer. The hand-axe and chopping tool were examined by XRD analysis and petrological microscopy. They had been fashioned on flat, hard cobbles that probably came from a fluvio-lacustrine gravel formed by erosion of mountainsides containing Mesozoic Jurassic Middle Lias beds of limestone containing a quartz component that rendered it particularly hard. By contrast, quartz was not detected in limestone cobbles that likely had been eroded from Middle Jurassic Dogger beds of Mesozoic limestone containing less quartz, and that, in the Cenozoic era, were incorporated into an Upper Miocene (Tortonian) conglomerate from which cobbles of limestone, quartzite and chert have been sampled at an outcrop $0.8 \mathrm{~km}$ east of Cueva Negra, and where artefacts resembling some excavated at the cave have been collected (Walker et al. 2006), as well as a small discoidal core, fashioned from chert, which was discarded after centripetal working had removed the last flake from it, as evidenced by the resulting flake scar (Walker et al. 2016a, Figure 3b). Notwithstanding the predominant presence of chipped artefacts of chert (flint) in the Palaeolithic assemblage at Cueva Negra (Walker et al., 2016a, Table 4c), attention is drawn to the fact that it was not chert but a particularly hard type of limestone on which the hand-axe and chopping tool were fashioned, though several small artefacts in the excavated Palaeolithic assemblage also are of limestone. A small discoidal limestone core with a central scar corresponding to the last flake removed from it was found on the surface beside the mouth of the cave (Walker et al. 2016a, Figure 3a); the core itself seems to have been fashioned from a very large flake of limestone rock.

In relation to the five-metre depth of sedimentary complexes Cx2, Cx3-1 and Cx3-2 (Figure 3), the small artefacts excavated in these are fundamentally similar throughout, both as regards technological aspects and rock-types (Walker et al., 2016a, Tables $4 \mathrm{c}, \mathrm{d}$ ), the latter include chert, limestone, marble, quartzite, quartz, and a single example of radiolarite. Laser-ablation inductively-coupled plasma mass spectrometry enabled analysis of trace-elements for "finger-printing" cherts, such that a sample from Cueva Negra could be compared and contrasted with samples obtained at several outcrops in and around the upper Quípar valley: 56 chert samples were analysed for 19 lanthanide and rare-earth trace elements, all of which afforded detectable values in those items (Zack et al. 2013). Factor analysis, applied to the values, differentiated between sources, and corroborated the plausible inference from field-work that an Upper Miocene (Tortonian) conglomerate outcrop $0.8 \mathrm{~km}$ east of the cave was the likely source of most of the excavated chert, though a small proportion (ca. 15\%) could have come from sources up to $30 \mathrm{~km}$ away (Zack et al. 2013). High-power microscopical inspection by one of us (I. M-L.) is underway of the steep and abrupt secondary knapping ("retouch") of "scraper" edges at Cueva Negra, with the detection of polish (cf., Keeley 1980; Gutiérrez 1996; Márquez et al. 2001; Martín-Lerma 2015) and striae (cf., Del Bene 1979; Mansur-Franchomme 1980) typical of those caused by application to animal skin or flesh (cf., Peretto 1994; Ollé 2003; Bello et al. 2009; Cristiani 2009; Lemorini et al. 2014, 2019; Viala 2020). Plausibly, they may well have been caused by the defleshing of herbivores and ruminants, such as those excavated at the cave, and initial inspection of polish and striae on other pieces (e.g., Figure 11) suggests their use on harder materials such as wood, bone or antler (cf., Crovetto et al. 1994; Pedergnana and Ollé 2017). Small artefacts often referred to in the Palaeolithic literature as beaks ("becs") rarely show microscopical signs of use-wear or edge-damage at Cueva Negra and probably were small cores from which very small flakes were removed for use as tools without secondary knapping, as has been proposed for similar pieces at the Italian site of Isernia La Pineta (Crovetto 1994; Crovetto et al. 1994a; Longo 1997; Peretto 1994; Peretto et al. 2004), and unretouched micro-flakes 5 - 15 mm in size abound in the Cueva Negra débitage. Occasionally, artefacts at Cueva Negra show evidence of re-use after patina had developed over earlier secondary knapping (cf., Parush et al. 2015).

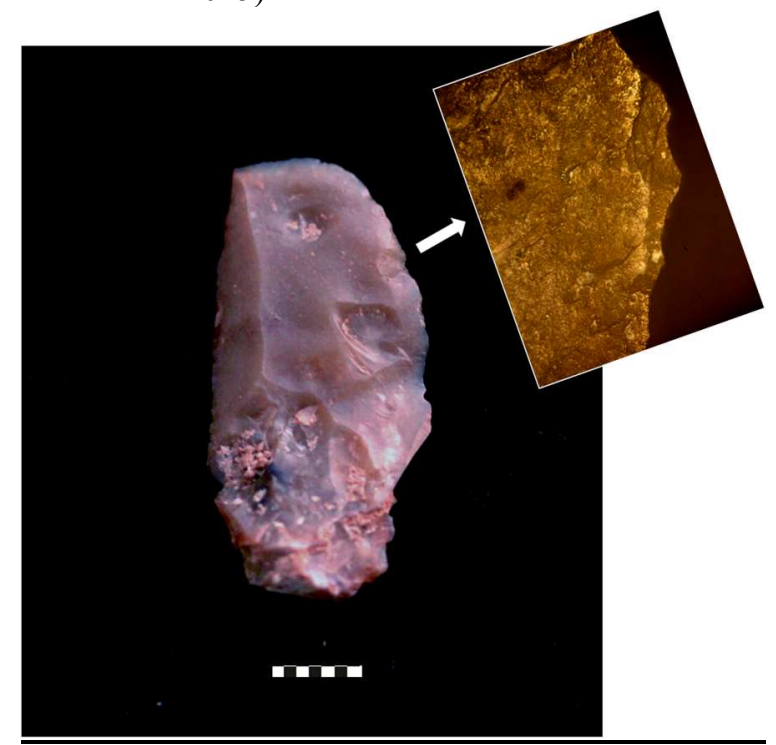

Figure 11. Flake from Cueva Negra with traces of use-wear characteristic of application to wood and subsequent secondary knapping indicating re-use (200x). Photo: I. Martín Lerma.

With very few exceptions indeed, the chipped stone elements are $<60 \mathrm{~mm}$ in size (Walker et al., 2016a). Secondary knapping, i.e., edge-"retouch", on struck flakes (that are defined by having a striking platform and bulb of percussion) was reported in 3\% of an excavated sample of 3,500 chipped stone pieces (Walker et al., 2016a, Table 4d), including on "microlithic" flakes $<30$ $\mathrm{mm}$ in size (e.g., Walker et al., 2016a, Figures 5d, 5p). Among chert (flint) flakes struck by repetitive or recurrent removal from 
cores are some that were excavated in "lithostratigraphical unit III" (which lies below"unit II $_{\mathrm{ii}}$ " that contained the hand-axe), including one with a facetted striking platform suggestive of preparation beforehand of the core for its hierarchical reduction (Walker et al. 2016a, Figure 2a), and another with the triangular shape that often characterises flakes that are removed when cores are reduced by centripetal flaking (Walker et al. 2016a, Figure 2b); in both cases, negative flake scars on the dorsal surface of these flakes indicate recurrent flaking of the cores.

Although the epithets "Acheulian", "Levalloisian" and "Mousteroid" had been applied at Cueva Negra (Walker et al. 2013), they have been replaced since (Walker et al. 2016a) by Shea's A-I modal descriptors (Shea 2013, 2016). Shea's modal approach relies on the same exclusionary principle and process of elimination that underpin "differential diagnosis" by medical practitioners, working backwards from the objects of study in order to whittle down mutually exclusive categories. An early archaeological practitioner was Yale's Irving Rouse (Rouse 1960; cf., Rouse 1939) who deployed it in the service of differential diagnosis of ceramic types by attribute discrimination. Modal analysis is helpful for analysing the differential composition of a lithic assemblage and defining it from the standpoint of the several technical modes represented in it. Such appreciation goes beyond regarding a prehistoric lithic assemblage as characterisable solely, or even mainly, in terms of the identification in it of a particular forward sequence of core reduction (perhaps detected by lithic refitting) or a particular operational sequence or "chaîne opératoire" (perhaps inferred from diacritical inspection of lithics). Shea's scheme is clinically aseptic, in so far as it avoids contamination from preconceived notions imbued with determinism, whether about essentialist mental concepts underpinning technical behaviour (e.g., Boëda, 1994; Boëda et al., 1990; Geneste, 1985), essentialist quasi-biological presumptions about Palaeolithic technology having evolved in homotaxial relation to evolution of different hominid species (e.g., "modes 1-5" of Clark 1969, or "1-6" of Clark 1970), or the ecological determinism that tinges some interpretations of lithic reduction sequence studies (for discussion of interactions between different standpoints, see Bar-Yosef and Van Peer 2009; Bleed 2001; Shott 2003; Tostevin 2011). Shea's approach can lead to a consideration of how far it is helpful or useful to embrace particular Palaeolithic assemblages with labels such as "Oldowan", “Acheulian", "Mousterian", "Levalloisian”, or Grahame Clark's "modes 1, 2, 3". They raise methodological and epistemological problems. Foremost among them is how far it is useful to speak of "the Acheulian" in general, or, more specifically, an Acheulian "tradition" (Lycett and Gowlett, 2008), an Acheulian "identity" (Butzer, 1971, p. 448), or an Acheulian "technocomplex" (Sharon and Barsky, 2016). The unhyphenated term "technocomplex" was coined (Clarke 1968, p. 331) for assemblages with spatio-temporal spreads of $\leq 5,000 \mathrm{~km}$ in radius and $\leq 20,000$ years (e.g., Solutrian, Magdelanian), in contrast to more circumscribed "culture groups" on the one hand, and, on the other, wide-ranging "industries" regarded (Clarke 1968, p. 667) as sets "of single-material artefact-type assemblages from a continuous space-time area, taxonomically linked by mutual technological affinities. Frequently, a single material aspect from a technocomplex entity" (e.g., Oldowan, Acheulian, Mousterian). Vast differences of temporal scale during the Pleistocene (cf., Bailey, 1983) raise substantive questions about the commensurability of various assemblages and "type-fossils" indiscriminately assigned to "the Acheulian". The probem with type-fossil approaches is that "Types are not groups of objects, but classes whose significata consist of sets of modes, stating the necessary and sufficient conditions of membership" (Dunnell, 1971, p. 159). A neurobiological propensity in Homo for flexible cognitive relationships could have arisen, spontaneously and independently, at widely-separated times and places, enabling manual dexterity to advance differential aptitudes for technical innovation, albeit sporadically. Bifacial working of stone has appeared, disappeared, and reappeared, from the mid-Early Pleistocene to the Holocene in Africa and Eurasia, and from the Late Pleistocene to the Holocene in Australia and the Americas (Brumm and Moore, 2012). An isolated appearance can be a sufficient rational conjecture for interpreting the Cueva Negra hand-axe parsimoniously, without requiring it also to exemplify a preconception of "the first Acheulean technology" in southern Spain, supposedly introduced from Africa by a conjectural "MIS 22 human dispersal associated with Acheulean tools" (Gibert, L., et al. 2016); moreover, the Cueva Negra faunal assemblage lacks specifically African faunal taxa.

Because, to date, no more than one hand-axe has been excavated at Cueva Negra, by classifying it as a "mode E1 elongated cutting tool" (Shea 2013, 2016) the matter is avoided of how many such tools need be present before labelling an assemblage "Acheulian" or "mode 2". In drawing attention to the problems that can arise from using a type-fossil name to label a Palaeolithic assemblage comprising diverse forms, Kleindienst (1961; cf., Kleindienst, 1962) proposed reserving the label "Acheulian" for those, mainly later, assemblages in which $40-60 \%$ of artefacts were bifacially-flaked hand-axes or cleavers, as Mary Leakey (1975) recalled though she did not refrain from using it at Olduvai (Leakey, 1971; Leakey and Roe, 1995). Nevertheless, "Oldowan" (or "mode 1") is unsuitable also for labelling the Cueva Negra assemblage, because, as at several early European sites, most artefacts at the cave (apart from a C1 unidirectionally-flaked chopping tool $>60 \mathrm{~mm}$ in size) are smaller than very many Oldowan artefacts from Olduvai (cf., Leakey, 1971; Leakey \& Roe, 1995). By side-stepping unhelpful labels, time-honoured may they be, Shea's scheme of modes A-I embraces a range of flexible cognitive relationships between stone workers and possibilities afforded by stones ("lithic affordances"). The Cueva Negra Palaeolithic assemblage has examples of Shea's technical modes A, B, C, D, E and F (and even perhaps sub-mode G1). Modification of Shea's modal descriptors appropriate for Cueva Negra may have to be entertained in the light of his forthcoming publication about the modal aplication to African stone artefacts (Shea, 2020). In correspondence with Shea we have indicated (cf., Walker et al. 2016a) that at Cueva Negra his mode C of pebble cores and non-hierarchical cores (Shea 2013, 158 Table 2) comprises four distinct groups, as follows: $\mathrm{C} 1>60 \mathrm{~mm}$, unidirectionally-flaked chopper; $\mathrm{C} 1<60 \mathrm{~mm}$, stubby or keeled non-hierarchically-worked pieces (small cores and nodules); $\mathrm{C} 2<60 \mathrm{~mm}$, showing both large non-hierarchical flake-scars and diminutive ones at the bevelled or chamfered tip of an elongated narrow spur that is defined by the large flake scars on a stubby or keeled piece (e.g., Walker et al. 2016a, Figures 4f-4m; cf., so-called "awls", "borers", "microperforators", "beaks", "becs"); C2 $<60 \mathrm{~mm}$, keeled plano-convex pieces the side and extremities of which bear non-hierarchical flake-scars (e.g., Walker et al. 2016a, Figures 4b-4e; cf., so-called "slugs", "limaces", "proto-limaces", "planes", "spoke-shaves"). Although there is evidence of bipolar working at Cueva Negra the small size of most pieces can render its identification uncertain; nor is it always possible to tell whether 
a flaked artefact had its origin in a small pebble core or in part of a big flake or fragment detached from a large block (analagous problems exist in other Palaeolithic assemblages, cf., Débenath and Dibble, 1004, 10).

The majority of artefacts excavated at Cueva Negra lack formal shape, which is unsurprising because raw materials most often available near Cueva Negra include relatively intractable cobbles of limestone, quartzite, and frangible, sub-parallelepiped pieces of tabular chert that, when struck, rarely affords conchoidal fractures or provides feathered flakes with convex bulbs of percussion and well-marked striking platforms. Most chert nodules are fissural (Stein, 1981, 537: "Fissural" [adj.], entered under "Fissure"; cf., "fissilità" Crovetto et al., 1994b, 87). They shatter often when struck, leaving only tiny chips and fragments. Sometimes, however, striking splits them apart along fissures or fissural flat planes, defined by the internal structure and impurities, resulting in flattish, sub-rectangular laminar pieces (Walker et al. 2013, Figure 17; Walker et al. 2016a, Figure 5s). Some of these underwent secondary knapping that modified a perpendicular margin by steep "retouch" to give it an acute angle (sub-mode D1) suitable for firm scraping and cutting (e.g., Walker et al. 2013, Figure 8; Walker et al. 2016a, Figures 5a and 5c right-hand piece). Although steep "retouch" applied to the edge of thin, feathered flakes can reduce the risk of snapping during use, well-formed feathered lakes are uncommon at Cueva Negra. Erosion of nearby escarpments caused displacement from Jurassic Mesozoic rock strata of chert (flint) nodules (where some weigh as much as five kilograms, $5 \mathrm{~kg}$ ) that in the Cenozoic era often underwent Miocene, Pliocene and Early Pleistocene rolling and battering, during processes, first, of marine, and, subsequently, continental erosion, followed by deposition in conglomerates or gravels (Walker et al. 2013). In consequence, readily available chert blanks and nodules are mostly small $(<100 \mathrm{~mm}$ in size, $<0.5 \mathrm{~kg}$ in weight).

The Cueva Negra Palaeolithic assemblage bears comparison with finds from the Spanish Catalonian sites of Barranc de la Boella near Tarragona, where a bifacially-flaked schist cleaver, trihedral "pick", and small chert flakes and denticulates date from between $1 \mathrm{Ma}$ and $0.870 \mathrm{Ma}$ (Vallverdú et al. 2014), and Vallparadís at Terrassa, where ESR and magnetostratigraphy indicate an age of $0.830 \pm 0.070 \mathrm{Ma}$ for an assemblage of small artefacts (some prepared by bipolar core-reduction), which included "becs," denticulate and notched pieces, "a few examples of centripetal cores and débordant flakes", and a chopping tool fashioned on a cobble (Barsky et al. 2013; Duval et al. 2012a; Garcia et al. 2011, 2012; Martínez et al. 2010). It is pertinent to remark here that centripetal reduction has been detected in the Italian Pirro Nord 13 assemblage possibly dating from ca. 1.3 Ma (Arzarello and Peretto 2010; Arzarello et al., 2012, 2015), considerably earlier than its appearance at Vallparadís and Cueva Negra. Furthermore, in East Africa, ca. 1.6 - 1.4 Ma at Peninj (Tanzania) there were not only hand-axes but also discoidal cores fashioned for "obtaining pre-determined flakes"(de la Torre et al. 2003; cf., de la Torre 2009; de la Torre and Mora 2008) though prior hierarchical core-preparation has been disputed (Díez Martín and Sánchez Yustos 2012; Díez Martín et al. 2012, 2015).

Prudence counsels against regarding the appearance in Africa and western Eurasia of a variety of analagous techniques for reducing stone cores as representing more than a general propensity in early Homo, from the middle of the Early Pleistocene onwards, for manual dexterity, technical capability and cognitive versatility (cf., de la Torre et al. 2003). In terms of natural selection, adaptive value could have been conferred by a general propensity underpinned by neurogenetics and neuroepigenetics (Manrique and Walker, 2017; Walker, 2016, 2017). Involvement of epigenetics carries implications for human biological reproduction that (a) transmission from progenitor to progeny was neither an inevitable nor a necessary outcome, and (b) that neurobiological evolution of the propensity could be non-linear and stall, with "snakes-and-ladders" consequences of appearances, disappearances and reappearances in the spatio-temporal spread of behavioural aptitudes (moreover, fragile, tiny, human groups can become extinct from extraneous circumstances beyond their control). Such implications complicate proposals based on solely genetic co-evolution of dual inheritance (e.g., Boyd and Richerson, 1986; Durham, 1991; Richerson and Mortensen, 2013) which could underpin transmisison of hand-axe reproducibility (Boyd and Richerson, 2005 pp. 54-57, Fig.3.1; Lycett and Gowlett, 2008). The notion of neurobiological propensity is compatible with sporadical appearance of hand-axes in an otherwise different lithic assemblage, as at Cueva Negra. It is also compatible with their notoriously variable Pleistocene distribution across the Old World. This underlies long-standing disputes about Hallam Movius' "Line" (Movius, 1948) and the appropriateness of using a common Old World ("Acheulian") terminology that includes elongated cutting tools bearing flake scars on two opposite faces which exist in eastern Asia (Brumm and Moore, 2012, Corvinus, 2004; Dennell, 2015; Lycett and Bae, 2010; Lycett and Chauhan, 2010; Lycett and Norton, 2010; Norton and Braun 2010; Petraglia and Shipton 2008, 2009).

Fire implies human cognitive capability at Cueva Negra, comparable to that at the Old World sites with combustion and hand-axes which are Wonderwerk Cave ca. 1 Ma in South Africa (Berna et al. 2012) and Gesher Benoth Ya'aqov ca. 0.78 Ma in Israel (Alperson-Afil 2012; Alperson-Afil and Goren-Inbar 2020; Goren-Inbar 2004). The small and "microlithic" components of the Cueva Negra assemblage resemble some in the Early Pleistocene assemblage from Bizat Ruhama in Israel (Zaidner 2013) within the Matuyama chron (Laukhin et al. 2001), and small flakes produced by pebble-core reduction were present ca. 1.6 - 1.4 Ma at 'Ubeidiya (Bar-Yosef and Goren Inbar 1993; Shea and Bar-Yosef 1999; Tchernov, 1988) where hand-axes were present ca. 1.4 1.2 Ma. Earlier examples of hand-axes in Israel were reported from Nahal Zihor ca. 1.6 Ma (Grosman et al., 2011). Hand-axes were present in India at Attirampakkan ca. 1.5 Ma (Pappu et al., 2011) and Isampur ca. 1.27 Ma (Paddaya et al., 2002). However, only "Oldowan" chopping tools accompanied the small-brain H.erectus ergaster georgicus at Dmanisi in Georgia ca. $1.8 \mathrm{Ma}$ (Baena et al., 2010; Celiberti et al., 2004; de Lumley et al., 2005; Džaparidze et al., 1992; Gabounia and Vekua, 1995; Gabunia et al., 1999; Garcia et al., 2010; Lordkipanidze et al., 2013; Rightmire et al., 2006). As mentioned in the Introduction, there are Palaeolithic assemblages without bifacial artefacts in Spain before $1 \mathrm{Ma}$, e.g., the Atapuerca Sima del Elefante where artefacts and fragmentary Homo sp. fossils were excavated in sediments dated to ca. 1.2 - 1.1 Ma (Bermúdez de Castro et al. 2011; Carbonell et al. 2008; de Lombera-Hermida et al. 2015; Huguet et al. 2017; Parés et al. 2006; Rosas et al. 2006), and at the eastern Andalusian sites of Barranco León-5, where tooth fragments assigned to Homo sp. were found, and Fuente Nueva-3, which dated from 1.4 - 1.2 Ma 
(Álvarez et al., 2015; Barsky et al., 2015; Carbonell and Rodríguez, 2006; de Lumley et al., 2009; Duval et al., 2012a,b; Fajardo 2009; Gibert, J. et al., 1998; 1999a,b, 2001; Martínez-Navarro et al., 1997; Oms et al., 2000; Ribot et al., 2015; Toro-Moyano et al., 2003, 2009, 2010, 2011, 2013). Different conjectures have been put forward about how often Early Pleistocene Homo was present in western Europe, about possibly available routes of access from Africa, and about what were the corresponding technological behaviours (Bar-Yosef and Belfer Cohen, 2001; Carrión and Walker, 2019; Galliotti and Mussi, 2018; Gibert, L. et al., 2016; GorenInbar and Gonen, 2006: Goren-Inbar et al., 2000; Hovers and Braun, 2009; Ollé et al., 2016; Sharon and Barsky, 2016; Shea, 2013, 2016; Vallverdú et al., 2014; Walker, 2017). Detailed analysis of the various conjectures falls outwith the scope of this Discussion.

Suffice it to say that self-justifying conjectures must be eschewed about notional palaeoanthropological and palaeodemographical associations with Palaeolithic technologies, let alone about their conjectural long-distance or inter-continental displacements. It is enough here to indicate that comparable to several Cueva Negra items are some small chert artefacts, excavated together with larger pieces at Fuente Nueva-3 and Barranco León-5 which are near Orce in the northern part of the Guadix-Baza Basin in Granada, barely $50 \mathrm{~km}$ from Cueva Negra. The lithic diversity of the Cueva Negra assemblage reflects cognitive capacity for technical competence, and underlines the pertinence of reflexions by others that have taken note of the lithic diversity and variability of European Early Pleistocene assemblages (Barsky 2009; Barsky et al. 2013, 2015; Carbonell et al. 2009). It has to be remarked, nevertheless, that the Cueva Negra Palaeolithic assemblage shows scant resemblance either to the assemblages of ca. 1.2 - 1.1 Ma from the Atapuerca Sima del Elefante, or those from layers TD6-TD4 of the Atapuerca Gran Dolina (Carbonell et al., 1995, 1999; Mallol, 1999; Terradillos, 2010) attributable to H.antecessor that dates from 949-772 ka (Duval et al., 2018) and therefore was contemporary with Cueva Negra. An accomodative conjecture mioght be that whereas possible demographical displacements in western Eurasian latitudes of low relief could have occurred in response to palaeoenvironmental fluctuations during the Pleistocene (Hosfield 2016), nevertheless the high topographical relief of regions around the northern shore of the Mediterranean Sea could have favoured a variety of idiosyncratically local responses by small, environmentally-restricted, human communities (Carrión and Walker 2019; Walker 2017). Of plausible relevance here is the likeliihood of the adaptability of later Early Pleistocene humans with regard to availability of resources and their seasonal variability in northern Mediterranean landscapes (Carrión and Walker 2019; Walker 2017). Microstratigraphical analysis shows that Palaeolithic activity at Cueva Negra was discontinuous (Fernández et al., 2018), doubtless on account of sporadical incursions of water, overflowing (perhaps seasonally) from the erstwhile lake nearby, fed by the Quípar River, and responsible for the alluvial sediments deposited in the rock-shelter. Conceivably, human absences favoured accumulation in the rock-shelter of remnants of small vertebrates that had succumbed to foxes, lynxes, and birds of prey (non-human impingement is implied by taphonomical considerations: Rhodes et al. 2016; Walker et al. 2016b). Currently the object of doctoral research by G. Linares-Matás at Oxford University are bones showing cut-marks and others with signs of gnawing which have been excavated in several levels that contained Palaeolithic artefacts. In particular, excavation in 2019 of the uppermost sediments at the rear of the rock-shelter, hitherto unexplored, uncovered bones of large carnivores, including hyaena and bear, and large herbivores, including giant deer and horse. Moreover in the 1990's remains of bison, rhinoceros, and a Proboscidean were found in the uppermost sediments, adjacent to the 2019 excavation, which were near the mouth of the cave, and preliminary taphonomical observations from the uppermost sediments imply that the cave may have become a haunt of carnivores after humans had ceased to frequent it. In any case, the biodiversity manifested by the excavated remains throughout the sedimentary sequence is undoubted testimony to the importance of the habitat that the rock-shelter afforded to several species that frequented it, though the complex stratigraphical palimpsest, to which they contributed, renders it hard to disentangle, with accuracy and precision, the part played by its Palaeolithic visitors. It is opportune, with a view to suggesting a possible analogy, to offer brief remarks on a contemporaneous site in Spain where research is further advanced and suggests an appropriate direction for future scientific inquiry at Cueva Negra. The principal site of reference is, of course, the Atapuerca Gran Dolina level TD6 where primary human utilisation of animal carcasses is implied by a cut-mark on bone interrupted by a later tooth-mark attributed to gnawing by a scavenging animal (Blasco and Rosell 2009). The size of most gnaw-marks from TD6 implies teeth of small carnivores such as foxes; moreover, cutmarks and other traces of human intervention there are similar on skeletal parts of both large and small prey, which would have been unexpected were large carnivores to have gained prior access (Carbonell and Rosell 2004). Intervention by early humans is not unthinkable (Díez and Rosell 1998; Díez et al. 1999) and given credence both by a range of impingements on carcasses that implicates human agency (Saladié et al. 2011, 2014), and by mathematical modelling of plausible environmental carrying capacity (Rodríguez-Gómez et al. 2013). Although taphonomical research at Cueva Negra is at an early stage, comparability with other Spanish Early Pleistocene sites can be entertained as a possible expectation.

\section{$\underline{\text { Conclusion }}$}

The Cueva Negra del Estrecho del Río Quípar offers evidence of intermittent Palaeolithic activity after the close of the Jaramillo sub-chron ca. $0.99 \mathrm{Ma}$ and before the Matuyama-Brunhes boundary of $0.772 \mathrm{Ma}$, which period is demonstrated in particular by presence of Megaloceros novocarthaginiensis in the magnetostratiphical context of reverse magnetic polarity. ESR chronology and other palaeontological data from the site are compatible with the aforementioned period, to which the sedimentary sequence is assigned, as are comparable aspects of Palaeolithic activities recorded at other contemporaneous Spanish sites. Likewise, evidence of combustion at Cueva Negra is broadly commensurable in time with that, from the Matuyama-Brunhes boundary, at Gesher Benot Ya'aqov at the easterm end of the circum-Mediterranean region. A reasonable palaeobiological inference is that cognitive versatility facilitated human survivability in the extended geographical and ecological ranges of the genus Homo towards the close of the Early Pleistocene.

\section{Acknowledgements}

M.J. Walker, M. Haber Uriarte, A. López Jiménez, M. López Martínez and I Martín Lerma express their gratitude for 
scientific or technical contributions made by all coauthors with them of publications cited here, and for assistance that has enabled research at Cueva Negra given by members of the Murcian Association for the Study of Palaeoanthropology and the Quaternary (MUPANTQUAT) and University of Murcia Research Group 005-11 "Ecce Homo (Evolución Cenozóico Cuaternario Ecología Homo)", the Caravaca de la Cruz town council, the director and staff of the Colegio Público Ascruz de Educación Especial at Caravaca, the Servicio de Patrimonio Histórico of the Dirección General de Bienes Culturales of the Comunidad Autónoma de la Región de Murcia, and the land-owner of Cueva Negra D. Rafael Saura.

J. van der Made is a participant in research project PGC2018-093925-B-C31 of the Spanish Ministry of Science, Innovation and Universities, and acknowledges assistance and access to fossil material given by C. Argot, J.M. Bermúdez de Castro, C. Brauckmann, E. Carbonell, E. Cioppi, M. Comas, A. Currant, T. Engel, C. Ferrández-Cañadell, S. Fraile, M. Gamazo, J. Gibert, L. Gibert, A. González Alonso, E. Gröning, N. Ibañez, R. Kahlke, P. Kamminga, W. von Koenigswald, H. Lutz, D. Mania, M. Martínez Andreu, H. Meller, S. van der Mije, M.R. Palombo, B. Sánchez Chillón, A. Sher, K. Stefaniak, and R. Ziegler. We particularly thank the following for their collaboration and conclusions: H-A. Blain (herpetology), A. Eastham (avian palaeontology), G. Rabeder (ursid palaeontology), X. Murelaga Bereicua (chelonian palaeaontology), G. Rabeder (ursid palaeontology), A. Rufà Bonache (avian palaeontology), and H. Bocherens and C. Wissing (stable isotope analysis).

The U-series and ESR dating studies have been funded by the Australian Research Council Future Fellowship Grant FT150100215. We are grateful to Les Kinsley, ANU, for his help on the LA-ICP-MS measurements. MD would also like to thank Verónica Guilarte Moreno, María Jesús Alonso Escarza, David Martínez Asturias, Javier Iglesias Cibanal and Carlos Sáiz Dominguez, CENIEH, for their support with sample preparation and gamma irradiation.

M.J. Walker acknowledges debts of gratitude to his mentor and friend, who twice visited Cueva Negra, the late Dr. Derek Roe, expert on the Acheulian and collaborator with Mary Leakey at Olduvai, who was the first Professor of Palaeolithic Archaeology at the University of Oxford, to the late Professor John D. Evans who when Director of the Institute of Archaeology of University College London stimulated M.J. Walker's interest in Spain, to the Fellows amd Governing Body of The Queen's College, Oxford, who made possible the initiation of his field research in Spain, and to the University of Murcia which further facilitated that research and of which he is an Honorific Emeritus Professor following retirement from teaching.

\section{References}

Agustí, J., Blain, H-A., Furió, M., de Marfá, R., \& Santos-Cubedo, A. (2010). The early Pleistocene small vertebrate succession from the Orce region (Guadix-Baza basin, SE Spain) and its bearing on the first human occupation of Europe. Quaternary International, 223-224, 162-169.

Agustí, J., Lozano-Fernández, I., Oms, O., Piñero, P., Furió, M., Blain, H-A., López-García, J.M., Martínez-Navarro, B. (2015). Early to Middle Pleistocene rodent biostratigraphy of the Guadix-Baza. Quaternary International, 389, 139-147.

Alperson-Afil, N. (2012). Archaeology of fire: methodological aspects of reconstructing fire history of prehistoric archaeological sites. Earth-Science Reviews, 113, 111-119.

Alperson-Afil, N. \& Goren-Inbar, N., Eds. (2010). The Acheulian site of Gesher Benot Ya'aqov, Volume II: Ancient flames and controlled use of fire. London: Springer.

Álvarez, C., Parés, J.M., Granger, D., Duval, M., Sala, R., \& Toro, I. (2015). New magnetostratigraphic and numerical age of the Fuente Nueva-3 site (Guadix-Baza Basin, Spain). Quaternary International 389, 224-234.

Álvarez-Posada, C., Parés, J.M., Cuenca-Bescós, G., Van der Made, J., Rosell, J., Bermúdez de Castro, J.M., \& Carbonell, E. (2018). A post-Jaramillo age for the artefact-bearing layer TD4 (Gran Dolina, 1 Atapuerca): New paleomagnetic evidence. Quaternary Geochronology, 45, 1-8.

Angelucci, D., Anesin, D., López Martínez, M., Haber Uriarte, M., Rodríguez Estrella, T., \& Walker, M.J. (2013). Rethinking stratigraphy and site formation of the Pleistocene deposit at Cueva Negra del Estrecho del Quípar (Caravaca de la Cruz, Spain). Quaternary Science Reviews, 89, 195-199.

Arnold, L.J., Demuro, M., Parés, J.M., Arsuaga, J. L., Aranburu, A., Bermúdez de Castro, J.M., \& Carbonell, E., 2014. Luminescence dating and palaeomagnetic age constraint on hominins from Sima de los Huesos, Atapuerca, Spain. Journal of Human Evolution, 67, 85-107.

Arsuaga, J.L., Martínez, I., Arnold, L.J., Aranburu, A., Gracia-Téllez, A., Sharp, W.D., Quam, R.M., Falguères, C., Pantoja-Pérez, A., Bischoff, J., Poza-Rey, E., Parés, J.M., Carretero, J.M., Demuro, M., Lorenzo, C., Sala, N., Martinón-Torres, M., García, N., Alcázar de Velasco, A., Cuenca-Bescós, G., Gómez-Olivencia, A., Moreno, D., Pablos, A., Shen, C.-C., Rodríguez, L., Ortega, A.I., García, R., Bonmatí, A., Bermúdez de Castro, J.M., \& Carbonell, E. (2014). Neandertal roots; cranial and chronological evidence from Sima de los Huesos. Science, 344, 1358-1363.

Arsuaga, J-L., Martínez, I., \& Gracia, A. (2001). Analyse phylogénétique des hominidés de la Sierra de Atapuerca (Sima de los Huesos et Gran Dolina TD-6): l'évidence crânienne. L'Anthropologie, 105, 161-176.

Arsuaga, J.-L., Martínez, I., Lorenzo, C., Gracia, A., Muñoz, A., Alonso, O., \& Gallego, J. (1999). The human cranial remains from Gran Dolina Lower Pleistocene site (Sierra de Atapuerca, Spain). Journal of BHuman Evolution, 37, 431-457.

Arzarello, M., Pavia, G., Peretto, C., Petronio, C., \& Sardella, R. (2012). Evidence of an Early Pleistocene hominin presence at Pirro Nord (Apricena, Foggia, southern Italy): P13 site. Quaternary International, 267, 56-61.

Arzarello, M., \& Peretto, C. (2010). Out of Africa: The first evidence of Italian peninsula occupation. Quaternary International, 223, 65-70. 
Arzarello, M., Peretto, C., \& Moncel, M-H. (2015). The Pirro Nord site (Apricena, Fg, southern Italy) in the context of the first European peopling: Convergences and divergences. Quaternary International, 389, 255-263.

Azzaroli, A. (1952). L'alce de Sénèze. Paleontographia Italica, 47, 133-141.

Baena, J., Lordkipanidze, D., Cuartero, F., Ferring, R., Zhvania, D., Martín, D., Shelia, T., Bidzinashuili, G., Roca, M., \& Rubio, D. (2010). Technical and technological complexity in the beginning: the study of Dmanisi lithic assemblage. Quaternary International 223-224, 43-53.

Bailey, G.N. (1983). Concepts of time in Quaternary prehistory. Annual Review of Anthropology 12, 165-192.

Bar-Yosef, O. \& Belfer-Cohen, A. (2001). From Africa to Eurasia - early dispersals. Quaternary International 75, $19-28$.

Bar-Yosef, O. \& Goren-Inbar, N. (1993). The lithic assemblages of 'Ubeidiya. Jerusalem, "Qedem monograph 34”, Institute of Archaeology, The Hebrew University of Jerusalem.

Bar-Yosef, O. \& Van Peer, P. (2009). The chaine opératoire approach in Middle Paleolithic archaeology. Current Anthropology, $50,103-131$.

Barsky, D. (2009). An overview of some African and Eurasian Oldowan sites: Evaluation of hominin cognitive levels, technological advancement and adaptive skills. In: Hovers, E., \& D.R. Braun (Eds.), Interdisciplinary approaches to the Oldowan. Dordrecht: Springer, "Vertebrate Paleobiology and Paleoanthropology Series" (pp. 39-47).

Barsky, D., Garcia, J., Martínez, K., Sala, R., Zaidner, Y., Carbonell, E., \& Toro-Moyano, I. (2013). Flake modification in European Early and Early-Middle Pleistocene stone tool assemblages. Quaternary International,316, 140-154.

Barsky, D., Sala, R., Menéndez, L., Toro-Moyano, I. (2015). Use and re-use: Re-knapped flakes from the Mode 1 site of Fuente Nueva 3 (Orce, Andalucía, Spain). Quaternary International, 361, 21-33.

Bello, S. M., Parfitt, S. A., \& Stringer, C. (2009). Quantitative micromorphological analyses of cut marks produced by ancient and modern handaxes. Journal of Archaeological Science, 36, 1869-1880.

Berger, G.W., Pérez-González, A., Carbonell, E., Arsuaga, J.L., Bermúdez de Castro, J.M., \& Ku, T.L. (2008). Luminescence chronology of cave sediments at the Atapuerca paleoanthropological site, Spain. Journal of Human Evolution, 55, $300-311$.

Bermudez de Castro, J.M., Arsuaga, J.L., Carbonell, E., Rosas, A., Martinez, I., \& Mosquera, M. (1997). A hominid from the Lower Pleistocene of Atapuerca, Spain: Possible ancestor to neandertals and modern humans. Science, 276, 1392-1395.

Bermúdez de Castro, J.M., \& Martinón-Torres, M. (2013a). A new model for the evolution of the human Pleistocene populations of Europe. Quaternary International, 295, 102-112.

Bermúdez de Castro, J.M., Martinón-Torres, M., Arsuaga, J.L., \& Carbonell, E. (2017). Twentieth anniversary of Homo antecessor (1997-2017): A review. Evolutionary Anthropology, 26, 157-171.

Bermúdez de Castro, J.M., Martinón-Torres, M., Blasco, R., Rosell, J., \& Carbonell, E. (2013b). Continuity or discontinuity in the European Early Pleistocene human settlement: the Atapuerca evidence. Quaternary Science Reviews, 76, 53-65.

Bermúdez de Castro, J.M., Martinón-Torres, M., Gómez-Robles, A., Prado-Simón, L., Laura Martín-Francés, L., Lapresa, Olejniczak, A., \& Carbonell, E. (2011). Early Pleistocene human mandible from Sima del Elefante (TE) cave site in Sierra de Atapuerca (Spain): A comparative morphological study. Journal of Human Evolution, 61, 12-25.

Berna, F., Goldberg, P., Horwitz, L.K., Brink, J., Holt, S., Bamford, M. \& Chazan, M. (2012). Microstratigraphic evidence of in situ fire in the Acheulean strata of Wonderwerk Cave, Northern Cape province, South Africa. Proceedings of the National Academy of Sciences of the USA, 109, 7593-7594.

Blain, H-A., (2019, pers. com.). Informe preliminar sobre el estudio de los anfibios y reptiles del Pleistoceno inferior final del yacimiento de Cueva Negra del Estrecho del Rio Quipar (Caravaca de la Cruz, Murcia): Campañas 2017-2019. Unpublished report.

Blasco, R., Blain, H.-A., Rosell, J., Díez, C., Huguet, R., Rodríguez, J., Arsuaga, J.L., Bermúdez de Castro, J.M., \& Carbonell, E. (2011). Earliest evidence for human consumption of tortoises in the European Early Pleistocene from Sima del Elefante, Sierra de Atapuerca, Spain. Journal of Human Evolution, 31, 503-509.

Blasco, R., \& Rosell, J. (2009). Who was the first? An experimental application of carnivore and hominid overlapping marks at the Pleistocene archaeological sites. Comptes Rendus Palevol, 8, 579-592.

Bleed, P. (2001). Trees or chains, links or branches: Conceptual alternatives for consideration of stone tool production and other sequential activities. Journal of Archaeological Method and Theory, 8, 101-127.

Boëda, E. (1994). Le concept Levallois: Variabilité des méthodes. Paris: "Centre de Recherches Archéologiques Monographie 9", Éditions du Centre National de la Recherche Scientifique.

Boëda, E., Geneste, J.-M., \& Meignen, L. (1990). Identification de chaînes opératoires lithiques du Paléolithique Ancien et Moyen. Paléo, 2, 43-80.

Bonifay, M.F. (1971). Carnivores Quaternaires du sud-est de la France. Mémoires du Muséum National d'Histoire Naturelle, ns, C $21(2), 1-378$.

Bour, R. \& Ohler, A.M. (2008). Chersine Merrem, 1820 and Chersina Gray, 1831: a nomenclatural survey. Zootaxa, 1752, 6-68.

Boyd, R. \& Richerson, P.J. (1985). Culture and the evolutionary process. Chicago and London: The University of Chicago Press.

Boyd, R. \& Richerson, P.J. (2005). The origin and evolution of cultures. Oxford and New York: Oxford University Press (esp. pp. 54-57 and fig. 3.1)

Brumm, A., \& Moore, M.W., 2012. Biface distributions and the Movius Line: A Southeast Asian perspective. Australian Archaeology 74, 32-46.

Budsky, A., Scholz, D., Gibert, L., Mertz-Kraus, R., (2015). ${ }^{230} \mathrm{Th} / \mathrm{U}$-dating of the Cueva Victoria flowstone sequence: Preliminary results and palaeoclimatic implications. Mastia, Revista del Museo Arqueológico Municipal de Cartagena "Enrique Escudero de Castro" (volumen temático: Ferrández-Cañadell, C., \& L. Gibert (Eds.), Geología y Palaeontología de Cueva Victoria) 11-12-13 (2012-2013-2014), 101-109. 
Butzer, K.W. (1971). Environment and archeology. An ecological approach to prehistiory. $2^{\text {nd }}$ edition. New York: Aldine (esp. p. 448).

Carbonell, E., Bermúdez de Castro, J.M., Arsuaga, J.L., Díez, J.C., Rosas, A., Cuenca-Bescós, G., Sala, R., Mosquera, M., \& Rodríguez, X.P. (1995). Lower Pleistocene hominids and artifacts from Atapuerca-TD6 (Spain). Science, 69, 826-830.

Carbonell, E., Bermúdez de Castro, J.M., Parés, J.M., Pérez-González, A., Cuenca-Bescós, G., Ollé, A., Mosquera, M., Huguet, R., Van der Made, J., Rosas, A., Sala, R., Vallverdú, J., García, N., Granger, A., Martiñón-Torres, M., Rodríguez, X.P., Stock, G.M., Vergès, J.M., Allue, E., Burjachs, F., Cáceres, I., Canals, A., Benito, A., Lozano, C.D.M., Mateos, A., Navazo, M., Rodríguez, J., Rosell, J., \& Arsuaga, J.L. (2008). The first hominin of Europe. Nature, 452, 465-469.

Carbonell, E., García-Antón, M., Mallol, C., Mosquera, M., Ollé, A., Rodríguez, X.P., Sahnouni, M., Sala, R., \& Vergès, J.M. (1999). The TD6 level lithic industry from Gran Dolina, Atapuerca (Burgos, Spain): Production and use. Journal of Human Evolution, 37, 653-693.

Carbonell, E., \& Rodríguez, X.P. (2006). The first human settlement of Mediterranean Europe. Comptes Rendus Palévol, 5, 291298.

Carbonell, E., \& Rosell, J. (2004). Ocupaciones de homínidos en el Pleistoceno de la Sierra de Atapuierca. In: Baquedano, E., \&S. Rubio Jara. (Eds.), Miscelánea en homenaje a Emiliano Aguirre Volumen IV Arqueología, Alcalá de Henares, Madrid: “Zona Arqueológica Número 4", Museo Arqueológico de la Comunidad de Madrid, Consejería de Presidencia, Justicia y Portavocía del Gobierno, Comunidad Autónoma de Madrid (pp. 103-115).

Carbonell, E., Sala, R., Barsky, D., \& Celiberto, V. (2009). From homogeneity to multiplicity: A new approach to the study of archaic atone tools. In: Hovers, E., \& D.R. Braun (Eds.), Interdsciplinary approaches to the Oldowan. Dordrecht: Springer, "Vertebrate Paleobiology and Paleoanthropology Series" (pp. 25-37).

Carrión, J.S. \& Walker, M.J., 2019. Background to Neanderthal presence in Western Mediterranean Europe. Quaternary Science Reviews, 217, 7-44.

Carrión García, J.S., Yll, E.I., Cháin, C., Dupré, M., Walker, M.J., Legaz, A., \& López, A. (2005). Fitodiversidad arbórea en el litoral del sureste español durante el Pleistoceno Superior. In: Sanjaume, E., \& J.F. Mateu (Eds.), Geomorfologia litoral $i$ Quaternari Homenatge al Profesor Vicenç Rosselló i Verger Estudios sobre Cuaternario Volumen Homenaje a V.Rosselló. Valencia: Universitat de València (pp. 103-112).

Carrión, J.S., Yll, E.I., Walker, M.J., Legaz, A., Chaín, C., \& López, A. (2003). Glacial refugia of temperate, Mediterranean and Ibero-North African flora in south-eastern Spain: New evidence from cave pollen at two Neanderthal man sites. Global Ecology and Biogeography, 12, 119-129.

Celiberti, V., Barsky, D., Cauche, D., Notter, O., Nioradze, M., Lordkipanidzé, D., Gabunia, L., \& de Lumley, H. (2004). Les industries lithiques archaïques du site de Dmanisi, Géorgie. In: Toussaint, M., Draily, C., \& J-M. Cordy (Eds.), Section 4: Premiers hommes et Paléolithique Inférieur/Human origins and the Lower Palaeolithic, General sessions and posters. Actes du XIVème Congrès UISPP, Université de Niège, Belgique, 2-8 septembre 2001/Acts of the XIVth UISPP Congress, University of Liège, Belgium, 2-8 September 2001. Oxford: Archaeopress, British Archaeological Reports, "BAR International Series S-1272" (pp. 29-36).

Cerdeño, E. (1993). Remarks on the Spanish Plio-Pleistocene Stephanorhinus etruscus (Rhinocerotidae). Comptes Rendus de l'Académie des Sciences, 317, 1363-1367.

Channell, J.E.T., Singer, B.S. and Jicha, B.R. (2020). Timing of Quaternary geomagnetic reversals and excursions in volcanic and sedimentary archives. Quaternary Science Reviews 228: 106114.

Clark, J.G.D. (1969). World prehistory. A new outline. Cambridge: Cambridge University Press.

Clark, J.G.D. (1970). Aspects of prehistory. Berkeley, Los Angeles, and London: University of California Press.

Clarke, D.L. (1968). Analytical archaeology. London: Methuen (esp. pp. 331, 667).

Corvinus, G. (2004). Homo erectus in East and Southeast Asia, and the questions of the age of the species and its association with stone artifacts, with special attention to handaxe-like tools. Quaternary International 117, 141-151.

Cristiani, E. (2009). A functional analyses of quartzite assemblage from the final Middle Pleistocene "Ribeira Ponte da Pedra/Atalaia" site (Central Portugal). In: de Araújo Igreja, M., \&C. Clemente-Conte. (Eds.), Recent functional studies on non flint stone tools: Methodological improvements and archaeological inferences, Proceedings of the workshop, Lisboa2325 May 2008. (CD-ROM, pp. 3-25) http://www.workshop-traceologia-lisboa2008.com.

Crovetto, C. (1994). Le industrie litiche. Analisi tecnico-tipologica dei reperti di scavo. In: C. Peretto (Ed.), Le industrie litiche del giacimento paleolitico di Isernia La Pineta: La tipologia, le tracce di utilizzazione, la sperimentazione. Isernia: Istituto Regionale per gli Studi Storici del Molise 'V. Cuoco', Cosmo Iannone (pp. 183-353).

Crovetto, C., Ferrari, M., Peretto, C., Longo, L., \& Vianello, F. (1994a). The carinated denticulates from the Palaeolithic site of Isernia La Pineta (Molise, Central Italy): Tools or flaking waste? The results of the 1993 lithic experiments. Human Evolution, 9, 175-207.

Crovetto, C., Ferrari, M., Peretto, C., \& Vianello, F. (1994b). Le industrie litiche. La scheggiatura, descrizione degli insiemi, i rimontaggi. In: C. Peretto (Ed.), Le industrie litiche del giacimento paleolitico di Isernia La Pineta: La tipologia, le tracce di utilizzazione, la sperimentazione. Isernia: Istituto Regionale per gli Studi Storici del Molise 'V. Cuoco', Cosmo Iannone (pp. 87-118).

Cuenca Bescós, G., Canudo, J.I., \& Laplana, C. (1995). Los arvicólidos (Rodentia, Mammalia) de los niveles inferiores de Gran Dolina (Pleistoceno inferior, Atapuerca, Burgos, España). Revista Española de Paleontología, 10, $202-218$.

Cuenca Bescós, G., Laplana, C., \& Canudo, J.I. (1999). Biochronological implications of the Arvicolidae (Rodentia, Mammalia) from the Lower Pleistocene hominid bearing level of Trinchera Dolina 6 (TD6, Atapuerca, Spain). Journal of Human Evolution, 37, 353-373. 
Cuenca-Bescós, G., Rofes, J., López-García, J.M., Blain, H-A., de Marfà, R.J., Galindo Pellicena, M.A., Bennásar-Serra, M.L., Melero-Rubio, M., Arsuaga, J.L., Bermúdez de Castro, J.M., \& Carbonell, E. (2010). Biochronology of Spanish Quaternary small vertebrate faunas. Quaternary International, 212, 109-119.

de la Torre, I. (2009). Technological strategies in the Lower Pleistocene at Peninj (West of Lake Natron, Tanzania). In: Toth, N., \& K. Schick (Eds.), The cutting edge: New approaches to the archaeology of human origins. Gosport, Indiana (and Bloomington, University of Indiana): "Stone Age Institute Publication Series Number 3", The Stone Age Institute, Stone Age Institute Press (pp. 93-113).

de la Torre, I., \& Mora, R. (2008). The early Acheulean in Peninj (Lake Natron, Tanzania). Journal of Anthropological Archaeology, 27, 244-268.

de la Torre, I., Mora, R., Domínguez-Rodrigo, M., de Luque, L., \& Alcalá, L. (2003). The Oldowan industry of Peninj and its bearing on the reconstruction of the technological skills of Lower Pleistocene hominids. Journal of Human Evolution, 44, 203-224.

de Lapparent de Broin, F., Bour, R., Parham, J.F., Perälä, J. (2006a). Eurotestudo, a new genus for the species Testudo hermanni Gmelin, 1789 (Chelonii, Testudinidae). Comptes Rendus Palevol, 5, 803-811.

de Lapparent de Broin, F., Bour, R., Parham, J.F., Perälä, J. (2006a). Morphological definition of Eurotestudo (Testudinidae, Chelonii): Première partie. Annales de Paléontologie, 92, 255-304.

de Lapparent de Broin, F., Bour, R., Parham, J.F., Perälä, J. (2006a). Morphological definition of Eurotestudo (Testudinidae, Chelonii): Deuxième partie. Annales de Paléontologie, 92, 325-357.

de Lombera-Hermida, A., Bargallo, A., Terradillos-Bernal, M., Huguet, R., Vallverdú, J., García-Antón, M.D., Mosquera, M., Ollé, A., Sala, R., Carbonell, E., \& Rodríguez-Álvarez, X.P. (2015). The lithic industry of Sima del Elefante (Atapuerca, Burgos, Spain) in the context of Early and Middle Pleistocene technology in Europe. Journal of Human Evolution, 82, 95-106.

de Lumley, H., Barsky, D., \& Cauche, D. (2009). Archaic stone industries from East Africa and southern Europe. Pre-Oldowan and Oldowan. In: Schick, K., \& N. Toth (Eds.), The cutting edge: New approaches to the archaeology of human origins. Gosport, Indiana (and Bloomington, University of Indiana): "Stone Age Institute Publication Series Number 3", The Stone Age Institute, Stone Age Institute Press (pp. 55-91).

de Lumley, H., Nioradze, M., Barsky, D., Cauche, D., Celiberti, V., Nioradze, G., Notter, O., Zvania, D., \& Lordkipanidze, D.(2005). Les industries préoldowayennes du début du Pléistocène Inférieur du site de Dmanissi en Géorgie. L'Anthropologie 109, 1182.

de Lumley-Woodyear, M-A. (1973). Anténéandertaliens et néandertaliens du basin méditerranéen occidental européen. Marseille: Université de Provence - Centre Saint-Charles: Études Quaternaires Géologie, Paléontologie, Préhistoire, "Mémoire no 2".

del Bene, T.A. (1979). Once upon a striation: Current models of striation and polish formation. In: Hayden, B. (Ed.), Lithic use-wear analysis. New York: Academic Press (pp. 167-177).

Debénath, A. \& Dibble, H.L. (1994). Handbook of Paleolithic typology. Volume One. Lower and Middle Paleolithic of Europe. Philadelphia: University of Pennsylvania, The University Museum.

Demuro, M., Arnold, L.J., Parés, J.M. \& Sala, R. (2015). Extended-range luminescence chronologies suggest potentially complex bone accumulation histories at the Early-to-Middle Pleistocene palaeontological site of Huéscar-1 (Guadix-Baza basin, Spain). Quaternary International, 389, 191-212.

Dennell, R. (2015). Life without the Movius Line: The structure of the East and Southeast Asian early Palaeolithic. Quaternary International 400, 14-22.

Díez, J.C., \& Rosell, J. (1998). Estrategias de subsistencia de los homínidos de la Sierra de Atapuerca. In: Aguirre, E. (Ed.), Atapuerca y la evolución humana. Madrid: Fundación Ramon Areces (pp. 361-390).

Díez, J.C., Fernández-Jalvo, Y., Rosell, J., \& Cáceres, I. (1999). Zooarchaeology and taphonomy of Aurora Stratum (Gran Dolina, Sierra de Atapuerca, Spain). Journal of Human Evolution, 37, 623-652.

Díez Martín, F., Cuartero, F., Sánchez Yustos, P., Baena, J., Rubio, D., \& Domínguez Rodrigo, M. (2012). Testing cognitive skills in Early Pleistocene hominins: An analysis of the concepts of hierarchization and predetermination in the lithic assemblages of Type Section (Peninj, Tanzania) In: Domínguez-Rodrigo, M. (Ed.), Stone tools and fossil bones: Debates in the archaeology of human origins. Cambridge and New York: Cambridge University Press (pp. 245-309).

Díez Martín, F., \& Sánchez Yustos, P. (2012). El origen del achelense: Un estado de la cuestión. Boletín del Seminario de Arte y Arqueología, Arqueología, (BSAA, Arqueología), 77-78 (2011-2012), 9-51. (Valladolid: Universidad de Valladolid, Servicio de Publicaciones).

Díez Martín, F., Sánchez Yustos, P., Gómez González, J. A., de Luque, L., Fraile Martínez, C., Duqye Martínez, J., \& de Francisco Rodríguez, S. (2015). El yacimiento achelense antiguo EN1-Noolchalai (Peninj, lago Natrón, Tanzania): Una visión geoarqueológica y tecnológica. Informes y Trabajos Excavaciones en el Exterior 2013, 12/2015, 345-358. (Madrid: Ministerio de Educación, Cultura y Deporte, Secretaría General Técnica, Subdirección General de Documentación y Publicaciones).

Dunnell, R.C. (1971). Systematics in prehistory. New York: The Free Press.

Durham, W.H. (1991). Coevolution: Genes, culture and human diversity. Stanford: Stanford University Press.

Duval, M., Falguères, C., \& Bahain, J-J. (2012a). Age of the oldest hominin settlements in Spain: Contribution of the combined Useries/ESR dating method applied to fossil teeth. Quaternary Geochronology 10, 412-417.

Duval, M., Falguères, C., Bahain, J-J., Grün, R., Shao, Q., Aubert, M., Dolo, J-M., Agustí, J., Martínez-Navarro, B., Palmqvist, P., \& Toro-Moyano, I. ( 2012b). On the limits of using combined U-series/ESR method to date fossil teeth from two Early Pleistocene archaeological sites of the Orce area (Guadix-Baza basin, Spain), Quaternary Research 77, 482-491. 
Duval, M., Grün, R., Parés, J.M., Martín-Francés, L., Campaña, I., Rosell, J., Shao, Q., Arsuaga, J.L., Carbonell, E., \& Bermúdez de Castro, J.M. (2018). The first direct ESR dating of a hominin tooth from Atapuerca Gran Dolina TD-6 (Spain) supports the antiquity of Homo antecessor. Quaternary Geochronology, 47, 120-137.

Džaparidze, V., Bosinski, G., Bugianišvili, T., Gabunia, L., Justus, A., Klopotovskaja, N., Kvavadze, E., Lordkipanidze, D., Majsuradze, G., Mgeladze, N., Nioradze, M., Pavlenišvili, E., Schmincke, H-U., Sologašvili, D., Tušabramišvili, D., Tvalčrelidze, M, \& Vekua, A. (1992). Der altpaläolithische Fundplatz Dmanisi in Georgien (Kaukasus). Jahrbuch des Römisch-Germanischen Zentralmuseums Mainz 36 Jahrgang 1989, 67-125.

Fajardo, B. (2009). The oldest occupation of Europe: Evidence from southern Spain. In: Schick, K., \& N. Toth (Eds.), The cutting edge: New approaches to the archaeology of human origins. Gosport, Indiana (and Bloomington, University of Indiana): "Stone Age Institute Publication Series Number 3", The Stone Age Institute, Stone Age Institute Press (pp. 115-136).

Falguères, C., Bahain, J-J., Yokoyama, Y., Arsuaga, J.L., Bermúdez de Castro, J.M., Carbonell, E., Bischoff, L., \& Dolo, J-M. (1999). Earliest humans in Europe: The age of TD6 Gran Dolina, Atapuerca, Spain.Journal of Human Evolution, 37, 343352.

Fejfar, O., Heinrich, W.D., \& Lindsay, E.H. (1998). Updating the Neogene rodent biochronology in Europe, Vol. 60. Haarlem: Mededelingen Nederlands Instituut voor Toegepaste Geowetenschappe (pp. 533-553).

Fernández, N., Haber, M., López, M., \& Walker, M.J. (2018). Cueva Negra del Estrecho del Río Quípar (Caravaca de la Cruz, Murcia, Spain): Intrasite analysis of a late Early Pleistocene Palaeolithic palimpsest. Proceedings of the European Society for the Study of Human Evolution 7, 63.

Forstén, A. (1988). The Middle Pleistocene replacement of the stenonid horses by the caballoid ones - ecological implications. Palaeogeography, Plaeoclimatology, Palaeoecology, 65 (1-2), 23-33.

Gabounia, L., \& Vekua, A.K. (1995). La mandibule de l'homme fossile du Villafranchien supérieur de Dmanissi (Géorgie Orientale). L'Anthropologie 99, 29-41.

Gabunia, L., Vekua, A., Lordkipanidze, D., Justus, A., Nioradze, M., \& Bosinski, G. (1999). Neue Urnmenschenfunde von Dmanisi (Ost-Georgien). Jahrbuch des Römisch-Germanischen Zentralmuseums Mainz, 46 Jahrgang 1999, 23-38.

Galliotti, R., \& Mussi, M., Eds. (2018). The emergence of the Acheulean in East Africa and beyond: Contributions in Honor of Jean Chavaillon. Cham: Springer International Publishing AG, "Vertebrate Paleobiology and Paleoanthropology Series".

Garcia, J., Martínez, K., \& Carbonell, E. (2011). Continuity of the first human occupation in the Iberian Peninsula: Closing the archaeological gap. Comptes Rendus Palevol, 10, 279-284.

Garcia, J., Martínez, K., Carbonell, E., Agustí, J., \& Burjachs, F. (2012). Defending the early human occupation of Vallparadís (Barcelona, Iberian Peninsula): A reply to Madurell-Malapeira et al. Journal of Human Evolution, 63, 568-575.

García, N., \& Arsuaga, J.L. (2001). Les carnivores (Mammalia) des sites des Pléistocène ancien et moyen d'Atapuerca (Espagne). L'Anthropologie, 105 (1), 83-94.

Garcia, T., Féraud, G., Falgguères, C., de Lumley, H., Perrenoud, C., \& Lordkipanidze, D. (2010). Earliest human remains in Eurasia: New ${ }^{40} \mathrm{Ar} /{ }^{39} \mathrm{Ar}$ dating of the Dmanisi hominid-bearing levels, Georgia. Quaternary Geochronology 5, $443-451$.

Geneste, M. (1985). Analyse lithique d'industries moustériennes du Périgord: Une approche technologique du comportement des groupes humaines au Paléolithique Moyen. Bordeaux: Université de Bordeaux (doctoral thesis).

Gibert, J., Gibert, L., Iglesias, A., \& Maestro, E. (1998). Two 'Oldowan' assemblages in the Plio-Pleistocene deposits of the Orce region, SE Spain. Antiquity, 72, 17-25.

Gibert, J., Gibert, L., Albadalejo, S., Ribot, F., Sánchez, F., \& Gibert, P. ( 1999a). Molar tooth fragment BL5-O: the oldest human remain found in the Plio-Pleistocene of Orce (Granada province, Spain). Human Evolution 14, 3-19.

Gibert, J., Gibert, L., \& Iglesias, A. (1999b). Acción antrópica e industrias líticas en la region de Orce, in: Gibert, J., Sánchez, F., Gibert, L., \& F.Ribot (Eds.), The hominids and their environment during the Lower and Middle Pleistocene of Eurasia, Proceedings of the International Conference of Human Palaeontology, Orce 1995/Los homínidos y su entorno en el Pleistoceno inferior y medio de Eurasia, Actas del Congreso Internacional de Paleontología Humana, Orce 1995. Orce, Ayuntamiento de Orce, Museo de Prehistoria y Paleontología “J.Gibert", (pp. 113-125).

Gibert, J., Gibert, L., Ferràndez-Canyadell, Iglesias, A., \& González, F. (2001). Venta Micena, Barranco León-5 and Fuentenueva3: three archaeological sites in the Early Pleistocene deposits of Orce, south-east Spain. In: Milliken, S. \& J. Cook (Eds.), $A$ very remote period indeed. Papers on the Palaeolithic presented to Derek Roe. Oxford: Oxbow Books (pp. 144-152).

Gibert, L., Scott, G.R. (2015). Edad del yacimiento de Cueva Victoria y su relación con otros yacimientos de la Península Ibérica, Mastia, Revista del Museo Arqueológico Municipal de Cartagena "Enrique Escudero de Castro" (volumen temático: Ferrández-Cañadell, C., \& L. Gibert (Eds.), Geología y Palaeontología de Cueva Victoria) 11-12-13 (2012-2013-2014), 85100.

Gibert, L., Scott, G.R., Martin, R, \& Gibert, J., (2007). The Early to Middle Pleistocene boundary in the Baza Basin (Spain). Quaternary Science Reviews 26, 2067-2089.

Gibert, L., Scott, G.R., Scholz, D., Budsky, A., Ferrández, C., Ribot, F., Martin, R.A., \& Leria, M. (2016). Chronology for the Cueva Victoria fossil site (SE Spain): Evidence for Early Pleistocene Afro-Iberian dispersals. Journal of Human Evolution, 90, 183-197.

Goren-Inbar, N., Alperson, A., Kislev, M.E., Simchoni, O., Melamed, Y., Ben-Nun, A., \& Werker, E. (2004). Evidence of hominin control of fire at Gesher Benot Ya'aqov, Israel. Science, 304, 725-727.

Goren-Inbar, N., Feibel, C.S, Verosub, K.L., Melamed, Y., Kislev, M.E., Tchernov, E., \& Saragusti, I. (2000). Pleistocene milestones on the Out-of-Africa corridor at Gesher Benot Ya'aqov, Israel. Science. 289, 944-947.

Goren-Inbar, N. \& Gonen, S., Eds. (2006). Axe age: Acheulian tool-making from quarry to discard. London: Equinox.

Grosman, L., Goldsmith, Y., \& Smilansky, U. (2011). Morphological analysis of Nahal Zihor handaxes: A chronological perspective. PaleoAnthropology 2011, 203-215. 
Grün, R. (2000). An alternative model for open system U-series/ESR age calculations: (Closed system U-series)-ESR, CSUS-ESR. Ancient TL, 18, 1-4.

Grün, R. \& Katzenberger-Apel, O. (1994). An alpha irradiator for ESR dating. Ancient TL, 12, 35-38.

Grün, R., Schwarcz, H.P., \& Chadam, J. (1988). ESR dating of tooth enamel: Coupled correction for U-uptake and U-series disequilibrium, International Journal of Radiation Applications and Instrumentation Part D Nuclear Tracks and Radiation Measurements, 14, 237-241.

Gutiérrez Sáez, C. (1996). Traceología. Pautas de análisis experimental. Madrid: Foro, “Temas de Arqueología 4, Arqueología Proyectos y Publicaciones".

Hosfield, R. (2016). Walking in a winter wonderland? Strategies for Early and Middle Pleistocene survival in mid-latitude Europe. Current Anthropology, 57, 653-682.

Hovers, E. \& Braun, D.R. Eds. (2009). Interdisciplinary approaches to the Oldowan. Dordrecht: Springer, "Vertebrate Paleobiology and Paleoanthropology Series".

Huguet, R., Vallverdú, J., Rodríguez-Alvarez, X.P., Terradillos-Bernal, M., Bargalló, A., Lombera-Hermida, A., Menéndez, L., Modesto-Mata, M., Van der Made, J., Soto, M., Blain, H.-A., García, N., Cuenca-Bescós, G., Gómez-Merino, G., PérezMartínez, R., Expósito, I., Allué, E., J. Rofes, J., Burjachs, F., Canals, A., Bennàsar, M., Nuñez-Lahuerta, C., Bermúdez de Castro, J.M., \& Carbonell, E. (2017). Level TE9c of Sima del Elefante (Sierra de Atapuerca, Spain): a comprehensive approach. Quaternary International, 433, 278-295.

Jiménez-Arenas, J.M., Santonja, M., Botella, M., \& Palmqvist, P. (2011). The oldest handaxes in Europe: Fact or artefact? Journal of Archaeological Science, 38, 3340-3349.

Kahlke, H.D. (1965). Die Cerviden-Reste aus den Tonen von Voigtstedt in Thüringen. Paläontologische Abhandlungen, A 2 (2/3), 379-426 (pls. 13-22).

Kahlke, H.D. (1969). Die Cerviden-Reste aus den Kiesen von Süssenborn bei Weimar. Paläontologische Abhandlungen, A 3 (3/4), 547-609.

Keeley, L.H. (1980). Experimental determination of stone tool uses. Chicago: University of Chicago Press.

Kleindienst, M.R. (1961). Variability within the Late Acheulian assemblages in eastern Africa. The South African Archaeological Bulletin 16, 35-52

Kleindienst, M.R. (1962). Components of the East African Acheulian assemblage: An analytical approach. In: Mortelmans, G. \& Nenquin, J. (Eds.), Actes du IVe Congrès Panafricain de Préhistoire et de l'Étude du Quaternaire, tome 3. Tervuren: Koninklijk Museum voor Midden-Afrika (pp. 81-111).

Koufos, G.D., Kostopoulos, D.S., \& Sylvestrou, I.A. (1997). Equus apolloniensis n.sp. (Mammalia, Equidae) from the latest Villafranchian locality of Apollonia, Macedonia, Greece. Paleontologia i Evolució, 30-31, 49-76.

Lacombat, F. (2006). Pleistocene Rhinoceroses in Mediterranean Europe and in Massif Central (France). Courier ForschungsInstitut Senckenberg, 256, 57-69.

Laukhin, S.A., Ronen, A., Pospelova, G.A., Sharonova, Z.V., Ranov, V.A., Burdukiewicz, J.M., Volgina, V.A., \& Tsatskin, A. (2011). New data on the geology and geochronology of the Lower Palaeolithic site Bizat Ruhama in the southern Levant. Paléorient, 27, 69-80.

Leakey, M.D., (1971). Olduvai Gorge. Volume 3, Excavations in Beds I and II, 1960-1963: Excavations in Beds I and II. Cambridge: Cambridge University Press.

Leakey, M.D. (1975). Cultural patterns in the Olduvai sequence. In: Butzer, K.W., \& G.L. Isaac (Eds.), After the Australopithecines. Stratigraphy, ecology and culture change in the Middle Pleistocene. The Hague and Paris: "World Anthropology", Mouton (pp. 477-494).

Leakey, M.D. \& Roe, D.A. (1995). Olduvai Gorge. Volume 5, Excavations in Beds II, III, and the Masek Beds, $1968-1971$. Cambridge: Cambridge University Press.

Lemorini, C., Bishop, L.C., Plummer, T.W., Braun, D.R., Ditchfield, P.W., \& Oliver, J.S. (2019). Old stones' song-second verse: Use-wear analysis of rhyolite and fenetized andesite artifacts from the Oldowan lithic industry of Kanjera South, Kenya. Archaeological and Anthropological Sciences, 11,4729-4754.

Lemorini, C., Plummer, T.W., Braun, D.R., Crittenden, A.N., Ditchfield, P.W., Bishop, L.C., Hertel, F., Oliver, J.S., Marlowe, F.W., Schoeninger, M.J., \&Potts, R. (2014). Old stones' song: Use-wear experiments and analysis of the Oldowan quartz and quartzite assemblage from Kanjera South (Kenya). Journal of Human Evolution, 72, 10-25.

Lisiecki, L.E., \& Raymo, M.E. (2005). A Plio-Pleistocene stack of 57 globally distributed benthic $\delta^{18} \mathrm{O}$ records. Paleoceanography, 20 PA 1003. DOI: 10.1029/2004PA001071,2005.

Longo, L., Peretto, C., Sozzi, M., \& Vannucci, S. (1997). Artefacts, outils ou support épuisés? Une nouvelle approche pour l'étude des industries du paléolithique ancien: Le cas d'Isernia La Pineta (Molise, Italie Centrale). L'Anthropologie, 101, $579-596$.

López-García, J.M., Cuenca Bescós, G., Blain, H-A., Cáceres, I., García, N., Gutiérrez, J.M., Santiago, A., \& Giles Pacheco, F. (2012). Biochronological data inferred from the early Pleistocene Arvicolinae (Mammalia, Rodentia) of the El Chaparral site (Sierra del Chaparral, Cádiz, southwestern Spain). Journal of Vertebrate Paleontology, 32, 1149-1156.

López Jiménez, A., Haber Uriarte, M., López Martínez, M., \& Walker, M.J. (2020). Small-mammal indicators of biochronology at Cueva Negra del Estrecho del Río Quípar (Caravaca de la Cruz, Murcia, SE Spain). Historical Biology, 32, 18-33, DOI: 10.1080/08912963.2018.1462804.

Lordkipanidze, D., Ponce de León, M.S., Margvelashvili, A., Rak, Y., Rightmire, G.P., Vekua, A., \& Zollikofer, C.P.E. (2013). A complete skull from Dmanisi, Georgia, and the evolutionary biology of early Homo. Science 342, 326-331.

Lycett, S.J. \& Bae, C.J.. (2010). The Movius Line controversy: The state of the debate. World Archaeology 42, $521-544$.

Lycett, S.J., \& Chauhan, P.R., Eds. (2010). New perspectives on old stones: Analytical approaches to Paleolithic technologies. New York, Dordrecht, Heidelberg, London: Springer Science+Business Media. 
Lycett, S.J. \& Gowlett, J.A. (2008). On questions surrounding the Acheulean "tradition". World Archaeology 40, $295-315$.

Lycett, S.J. \& Norton, C.J. (2010). A demographic model for Palaeolithic technological evolution: The case of East Asia and the Movius Line. Quaternary International 211, 55-65.

Mallol, C. (1999). The selection of lithic raw materials in the Lower and Middle Pleistocene levels TD6 and TD10A of Gran Dolina (Sierra de Atapuerca, Burgos, Spain). Journal of Anthropological Research, 55, 385-407.

Manrique, H.M., \& Walker, M.J. (2017). Early evolution of human memory: Great-apes, tool-making and cognition. Cham: Palgrave-Macmillan/Nature-Springer.

Mansur-Franchomme, M.E. (1980). Las estrías como microrrastros de utilización: Clasificación y mecanismos de formación. Antropología y Paleontología Humana, 2, 21-41.

Márquez, B., Ollé, A., Sala, R. \& Vergès, J.M. (2001). Perspectives methodologiques del'analyse fonctionnelle des ensembles lithiques du Pléistocène infèrieur et moyen d'Atapuerca (Burgos, Espagne)". L'Anthropologie, 105 (2), $281-299$.

Martin, R.A. (2015). A brief review of the Spanish archaic Pleistocene arhizodont voles. Mastia, Revista del Museo Arqueológico Municipal de Cartagena "Enrique Escudero de Castro" (volumen temático: Ferrández-Cañadell, C., \& L. Gibert (Eds.), Geología y Palaeontología de Cueva Victoria) 11-12-13 (2012-2013-2014), 207-225.

Martín-Lerma, I. (2015). Funcionalidad de la industria lítica magdaleniense del interior peninsular: La Peña de Estebanvela (Ayllón, Segovia). Madrid: UNED Universidad Nacional de Educación a Distancia (doctoral thesis).

Martínez, K., García, J., Carbonell, E., Agustí, J., Bahain, J.-J., Blain, H.-A., Burjachs, F., Cáceres, I., Duval, M., Falguères, C., Gómez, M., \& Huguet, R. (2010). A new Lower Pleistocene archaeological site in Europe (Vallparadís, Barcelona, Spain). Proceedings of the National Academy of Sciences of the USA, 107, 5262-5267.

Martínez, K., Garcia, J., Burjachs, F., Y11, R., \& Carbonell, E. (2014). Early human occupation of Iberia: the chronological and palaeoclimatic inferences from Vallparadís (Barcelona, Spain). Quaternary Science Reviews, 85, 136-146.

Martínez-Andreu, M., Montes-Bernárdez, R., \& San Nicolás-del Toro, M. (1989). Avance al estudio del yacimiento musteriense de la Cueva Negra de La Encarnación (Caravaca, Murcia). In Crónica XIX Congreso Nacional de Arqueología, Castellón de la Plana 1987, Ponencias y Comunicaciones Volumen I. Saragossa: Universidad de Zaragoza, Seminario de Arqueología, Secretariado de los Congresos Arqueológicos Nacionales, “Congresos Arqueológicos Nacionales" (pp. 973-983).

Martínez-Navarro, B., Turq, A., Agustí, J., \& Oms, O. (1997). Fuente Nueva-3 (Orce, Granada, Spain) and the first human occupation of Europe. Journal of Human Evolution, 33, 611-620.

Mazo, A.V., Sesé, C., Ruiz Bustos, A., \& Peña, J.A. (1985). Geología y paleontología de los yacimientos Plio-Pleistocenos de Huéscar (Depresión de Guadix-Baza, Granada). Estudios Geológicos, 41, 467-493.

Mazza, P., Sala, B., \& Fortelius, M. (1993). A small latest Villafranchian (Late Early Pleistocene) rhinoceros from Pietrafitta (Perugia, Umbria, central Italy), with notes on the the Pirro and Westerhoven rhinoceroses. Paleontographia italica, 80, 2550 .

Minwer-Barakat, R., Madurell-Malapeira, J., Alba, D.M., Aurell-Garrido, J., de Esteban-Trivigno, S., \& Moyà-Solà, S. (2011). Pleistocene rodents from the Torrent de Vallparadís section (Terrassa, northeastern Spain) and biochronological implications. Journal of Vertebrate Paleontology, 31, 849-865.

Morales Pérez, J.V., \& Sanchis Serra, A. (2009). The Quaternary fossil record of the genus Testudo in the Iberian Peninsula. Archaeological implications and diachronic distribution in the western Mediterranean. Journal of Archaeological Science 35, 1152-1162.

Movius, H.L. (1948). The lower Palaeolithic cultures of southern and eastern Asia. Transactions of the American Philosophical Society 38, 329-420.

Musil, R. (1969). Die Equiden-Reste aus dem Pleistozän von Süssenborn bei Weimar. Paläontologische Abhandlungen, 3 (3-4), 617-666.

Musil, R. (2001). Die Equiden-Reste aus dem Unterpleistozän von Untermassfeld. In: Kahlke, R.D. (Ed.) Das Pleistozän von Untermassfeld bei Meiningen (Thüringen). Teil 2. Bonn: Dr Rudolf Habelt GmBH (pp. 557-588).

Norton, C.J. \& Braun, D.R., Eds. (2010). Asian Paleoanthropology: From Africa to China and Beyond. Dordrecht: Springer Science+Business Media BV, "Vertebrate Paleobiology and Paleoanthropology Series".

Okada, M., Suganuma, Y., Haneda., Y., \& Kazaoka., O., 2017.Paleomagnetic direction and paleointensity variations during the Matuyama-Brunhes polarity transition from a marine succession in the Chiba composite section of the Boso Peninsula, central Japan. Earth, Planets and Space (2017), 69, 45. DOI: 10.1186/s40623-017-0627-1.

Ollé, A. (2003). Variabilitat i patrons funcionals en els sistemes tècnics de Mode 2. Anàlisi de les deformacions d'ús en els conjunts lítics del Riparo Esterno de Grotta Paglicci (Rignano Garganico, Foggia), Aridos (Arganda, Madrid) i Galería-TN (Sierra de Atapuerca, Burgos). Tarragona: Universitat Rovira i Virgili, Facultat de Lletres, Departament d'Història i Geografia (doctoral thesis).

Ollé, A., Mosquera, M., Rodríguez-Álvarez, X.P., García-Medrano, P., Barsky, D., de Lombera-Hermida. A., \& Carbonell. E. 2016. The Acheulean from Atapuerca: Three steps forward, one step back. Quaternary International 411 (Part B), $316-328$.

Oms, O., Parés, J.M., Martínez-Navarro, B., Agustí, J., Toro, I., Martínez-Fernández, G., \& Turq, A. (2000). Early human occupation of Western Europe: Paleomagnetic dates for two Paleolithic sites in Spain. Proceedings of the National Academy of Sciences of the USA, 97, 10667-10670.

Paddayya, K., Blackwell, B.A.B., Jhaldiyal, R., Petraglia, M.D., Fevrier, S., Chaderton II, D.A., Blickstein, J.I.B., \& Skinner, A.R. (2002). Recent findings on the Acheulean of the Hunsgi and Baichbal Valleys, Karnataka, with special reference to the Isampur excavation and its dating. Current Science 83, 641-647.

Pandolfi, L., Cerdeño, E., Codrea, V., \& Kotsakis, T. (2017). Biogeography and chronology of the Eurasian extinct rhinoceros Stephanorhinus etruscus (Mammalia, Rhinocerotidae). Comptes Rendus Palevol, 16, 762-773. 
Pappu, S., Gunnell, Y., Akhilesh, K., Braucher, R., Taieb, M., Demory, F., \& Thouvery, N. (2011). Early Pleistocene presence of Acheulian hominins in south India. Science 331, 1596-1599.

Parés, J.M., Álvarez, C., Sier, M., Moreno, D., Duval, M., Woodhead, J.D., Ortega, A.I., Campaña, I., Rosell, J., Bermúdez de Castro, J.M., \& Carbonell, E. (2018). Chronology of the cave interior sediments at Gran Dolina archaeological site, Atapuerca (Spain). Quaternary Science Reviews, 186, 1-16.

Parés, J.M., Arnold, L., Duval, M., Demuro, M., Pérez-González, A., Bermúdez de Castro, J.M., Carbonell, E., \& Arsuaga, J.L. (2013). Reassessing the age of Atapuerca-TD6 (Spain): New paleomagnetic results. Journal of Archaeological Science, 40, 4586-4595.

Parés, J.M., Peréz-González, A., Rosas, A., Benito, A., Bermúdez de Castro, J.M., Carbonell, E., \& Huguet, R. (2006). Matuyamaage lithic tools from the Sima del Elefante Site, Atapuerca (Northern Spain). Journal of Human Evolution, 50, $163-169$.

Parfitt, S.A., Barendregt, R.W., Breda, M., Candy, I., Collins, M.J., Coope, G.R., Durbidge, P., Field, M.H., Lee, J.R., Lister, A.M., Mutch, R., Penkman, K.E.H., Preece, R.C., Rose, J., Stringer, C.B., Symmons, R., Whittaker, J.E., Wymer, J.J., \& Stuart, A.J. (2005). The earliest record of human activity in northern Europe. Nature, 438, 1008-1012.

Parush, Y., Assaf, E., Slon, V., Gopher, A., \& Barkai, R. (2015). Looking for sharp edges: modes of flint recycling at Middle Pleistocene Qesem Cave, Israel. Quaternary international, 361, 61-87.

Pedergnana, A.,\& Ollé, A. (2017). Monitoring and interpreting the use-wear formation processes on quartzite flakes through sequential experiments. Quaternary International,427, 35-65.

Peretto, C. (Ed.). (1994). Le industrie litiche del giacimento paleolitico di Isernia la Pineta: La tipologia, le tracce di utilizzazione, la sperimentazione. Isernia: Istituto Regionale per gli Studi Storici del Molise 'V. Cuoco', Cosmo Iannone.

Peretto, C., Arzarello, M., Gallotti, R., Lembo, G., Minelli, A., \& Hohenstein, U.T. (2004). Middle Pleistocene behavioural strategies: The contribution of Isernia La Pineta (Molise, Italy). In: Baquedano, E., \& S. Rubio Jara (Eds.), Miscelánea en homenaje a Emiliano Aguirre Volumen IV Arqueología. Alcalá de Henares: Zona Arqueológica Número 4, Museo Arqueológico Regional (pp. 368-381).

Pérez-García, A., Boneta, I., Murelaga, X., Ferràndez-Cañadell, C., \& Gibert, L. (2015). Las tortugas del yacimiento del Pleistoceno inferior de Cueva Victoria (Murcia, España). Mastia, Revista del Museo Arqueológico Municipal de Cartagena "Enrique Escudero de Castro" (volumen temático: Ferrández-Cañadell, C., \& L. Gibert (Eds.), Geología y Palaeontología de Cueva Victoria), 11-12-13 (2012-2013-2014), 199-205.

Petraglia, M.D. \& Shipton, C. (2008). Large cutting tool variation west and east of the Movius Line. Journal of Human Evolution $55,962-966$.

Petraglia, M.D. \& Shipton, C. (2009). Erratum to "Large cutting tool variation west and east of the Movius Line. J.H..Evol. 55 (2008) 962-966". Journal of Human Evolution 57, 326-330.

Piñero, P., Agustí, J., Oms, O., Blain, H-A., Furió, M., Laplana, C., Sevilla, P., Rosas, A., \& Vallverdú, J. (2020). First continuous pre-Jaramillo to Jaramillo terrestrial vertebrate succession from Europe. Scientific Reports, 10, 1901.

Rhodes, S.E., Walker, M.J., López-Jiménez, A., López-Martínez, M., Haber-Uriarte, M., Fernández-Jalvo, Y., \& Chazan, M. (2016). Fire in the Early Palaeolithic: Evidence of small mammal burning at Cueva Negra del Estrecho del Río Quípar, Murcia, Spain. Journal of Archaeological Science Reports, 9, 427-436.

Ribot, F., Gibert, L., Ferràndez-Cañadell, F., García Olivares, E., Sánchez, F., \& Lería, M. (2015). Two deciduous human molars from the Early Pleistocene deposits of Barranco León (Orce, Spain). Current Anthropology 56, 134-142.

Richerson, P.J. \& Christiansen, M.H., Eds. (2013) Cultural evolution. Society, technology, language, and religion. Cambridge, Mass. and London: The MIT Press, "Strüngmann Forum Reports".

Rightmire, G.P., Lordkipanidze, D., \& Vekua, A. (2006). Anatomical descriptions, comparative studies and evolutionary significance of the hominin skulls from Dmanisi, Republic of Georgia. Journal of Human Evolution 50, $115-141$.

Rodríguez-Gómez, G., Rodríguez, J., Martín-González, J.A., Goikoetxea, I., \& Mateos, A. (2013). Modeling trophic resource availability for the first human settlers of Europe: the case of Atapuerca TD6. Journal of Human Evolution, 64, 645-657.

Rosas, A., Huguet, R., Pérez-González, A., Bermúdez de Castro, J.M., Vallverdú, J., Van der Made, J., Allué, E., García, N., Martínez-Pérez, R., Rodríguez, J., Sala, R., Saladie, P., Benito, A., Martínez-Maza, C., Bastir, M., Sánchez, A., \& Parés, J.M. (2006). The "Sima del Elefante" cave site at Atapuerca (Spain). Estudios Geológicos, 61, 327-248.

Rouse, I. (1939). Prehistory in Haiti: A study in method. New Haven: "Yale University Publications in Anthropology Number 21", Yale University.

Rouse, I. (1960). The classification of artifacts in archaeology. American Antiquity, 25, 313-323.

Saladié, P., Huguet, R., Díez, C., Rodríguez-Hidalgo, A., Cáceres, I., Vallverdú, J., Rosell, J., Bermúdez de Castro, J.M., \& Carbonell, E. (2011). Carcass transport decisions in Homo antecessor subsistence strategies. Journal of Human Evolution, $61,425-446$.

Saladié, P., Rodríguez-Hidalgo, A., Huguet, R., Cáceres, I., Díez, C., Vallverdú, J., Canals, A., Soto, M., Santander, B., Bermúdez de Castro, J.M., Arsuaga, J.L., \& Carbonell, E. (2014). The role of carnivores and their relationship to hominin settlements in the TD6-2 level from Gran Dolina (Sierra de Atapuerca, Spain). Quaternary Science Reviews, 93, 47-66.

Scott, G.R., \& Gibert, L. (2009). The oldest hand-axes in Europe. Nature, 461, 82-85.

Sharon, G. \& Barsky, D. (2016). The emergence of the Acheulian in Europe - A look from the east. Quaternary International 411 (Part B), 25-33.

Shea, J.J. (2013). Lithic modes A-I: A new framework for describing global-scale variationin stone tool technology illustrated with evidence from the East Mediterranean Levant. Journal of Archaeological Method and Theory, 20, 151-186.

Shea, J.J. (2016). Stone tools in human evolution: Behavioral differences among technological Primates. Cambridge and New York: Cambridge University Press.

Shea, J.J. (2020). Prehistoric stone tools of Eastern Africa. A guide. Cambridge and New York: Cambridge University Press. 
Shea, J.J. \& Bar-Yosef, O. (1999). Lithic assemblages from the new (1988-1994) excavations at 'Ubeidiya: A preliminary report. Journal of the Israel Prehistoric Society, 28, 5-20.

Shott, M.J. (2003). Chaîne opératoire and reduction sequence. Lithic Technology, 21, 6-22.

Stein, J. (Ed.) (1981). Random House dictionary of the English language. The unabridged edition. New York: Random House.

Stimpson, C.M., Lister, A., Parton, A., Clark-Balzan, L., Breeze, P.S., Drake, N.A., Groucutt, H.S., Jennings, R., Scerri, E.M.L., White, T.S., Zahir, M., Duval, M., Grün, R., Al-Omari, A., Al Murayyi, K.S.M., Zalmout, I.S., Mufarreh, Y.A., Memesh, A.M. and Petraglia, M.D. (2016). Middle Pleistocene vertebrate fossils from the Nefud Desert, Saudi Arabia: Implications for biogeography and palaeoecology. Quaternary Science Reviews 143 (Supplement C): 13-36.

Tchernov, E. (1988). The age of 'Ubeidiya formation (Jordan Valley, Israel) and the earliest hominids in the Levant. Paléorient 14, 63-65.

Terradillos Bernal, M. (2010). El Paleolítico Inferior en la Meseta Norte, España: Sierra de Atapuerca, La Maya, El Basalito, San Quirce y Amrbona. Estudio tecnológico y experimental. Oxford: "BAR International Series 2155", Archaeopress.

Toro-Moyano, I., Agustí, J., Martínez-Navarro, B. (Eds.) (2003). El Pleistoceno inferior del Barranco León y Fuente Nueva 3, Orce (Granada): Memoria científica campañas 1999-2002. Seville: “Arqueología Monografías 17”, Servicio de Investigación y Difusión del Patrimonio Histórico, Dirección General de Bienes Cultura, Consejería de Cultura, Junta de Andalucía.

Toro-Moyano, I., de Lumley, H., Fajardo, B., Barsky, B., Cauche, D., Celiberti, V., Grégoire, S., Martinez-Navarro, B., Espigares, M.P., \& Ros-Montoya, S. (2009). L'industrie lithique des gisements du Pléistocène inférieur de Barranco León et Fuente Nueva 3 à Orce, Grenade, Espagne. L'Anthropologie, 113, 114-124.

Toro-Moyano, I., de Lumley, H., Barrier, P., Barsky, D., Cauche, D., Celiberti, V., Grégoire, S., Lebègue, F., Mestour, B., \& Moncel, M.-H. (2010). Les industries lithiques archä̈ques de Barranco León et de Fuente Nueva 3. Orce, Bassin du Guadix-Baza, Andalousie. Paris: Éditions du Centre National de la Recherche Scientifique.

Toro Moyano, I., Barsky, D., Cauche, D., Celiberti, V., Grégoire, S., Lebegue, F., Moncel, M.H., \&de Lumley, H. (2011). The archaic stone tool industry from Barranco León and Fuente Nueva 3, (Orce, Spain): Evidence of the earliest hominin presence in southern Europe. Quaternary International, 243, 80-91.

Toro-Moyano, I., Martínez-Navarro, B., Agustí, J., Souday, C., Bermúdez de Castro, J.M., Martinón-Torres, M., Fajardo, B., Duval, M., Falguères, C., Oms, O., Parés, J.M., Anadón, P., Julià, R., García-Aguilar, J.M., Moigne, A.-M., Espigares, M.P., RosMontoya, S., \& Palmqvist, P. (2013). The oldest human fossil in Europe dated to ca. 1.4 Ma at Orce (Spain). Journal of Human Evolution, 65, 1-9.

Tostevin, G.B. (2011). Levels of theory and social practice in the reduction sequence and chaîne opératoire methods of lithic analysis. PaleoAnthropology 2011, 351-375.

Tsoukala, E.S. (1989). Contribution to the study of the Pleisocene fauna of large mammals (Carnivora, Perissodactyla, Artiodactyla) from Petralona Cave, Chalkidiki (N. Greece). Thessalonica: School of Geology, Aristotle University of Thessaloniki (doctoral thesis), Scientific Annals, 1 (8), 1-360 (pls. 1-62)

Turner, A. \& M. Antón, 1996. The giant hyaena, Pachycrocuta brevirostris (Mammalia, Carnivora, Hyaenidae). Geobios, 29, 455468.

Vallverdú, J., Saladié, P., Rosas, A., Huguet, R., Cáceres, I., Mosquera, M., Garcia-Tabernero, A., Estalrrich, A., Lozano-Fernández, I., Pineda-Alcalá, A., Carrancho, A., Villalaín, J.J., Bourlès, D., Braucher, R., Lebatard, A., Vilalta, J., Esteban-Nadal, M., Bennàsar, M.L., Bastir, M., López-Polín, L., Ollé, A., Vergé, J.M., Ros-Montoya, S., Martínez-Navarro, B., García, A., Martinell, J., Expósito, M., Burjachs, F., Agustí, J., \& Carbonell, E. (2014). Age and date for early arrival of the Acheulian in Europe (Barranc de la Boella, la Canonja, Spain). Public Library of Science One (PLoS ONE), 9, e103634.

Van der Made, J. (1999). Ungulates from Atapuerca-TD6. Journal of Human Evolution, 37, 389-413.

Van der Made, J. (2010). The rhinos from the Middle Pleistocene of Neumark Nord (Saxony-Anhalt). Los rinocerontes del Pleistoceno Medio de Neumark Nord (Sajonia-Anhalt). Veröffentlichungen des Landesamtes für Archeologie 62 (NeumarkNord - ein interglaziales Öksoystem des mittelpaläolithischen Menschen) (pp. 432-527).

Van der Made, J. (2015a). The latest Early Pleistocene giant deer Megalcoeros novocarthaginiensis n. sp. and the fallow deer Dama cf. vallonnetensis from Cueva Victoria (Murcia, Spain). El ciervo gigante del último Pleistoceno temprano Megaloceros novocarthaginiensis n. sp. y el gamo palmeado Dama cf. vallonnetensis de Cueva Victoria (Murcia, España). Mastia, Revista del Museo Arqueológico Municipal de Cartagena "Enrique Escudero de Castro" (volumen temático: Ferrández-Cañadell, C., \& L. Gibert (Eds.), Geología y Palaeontología de Cueva Victoria) 11-12-13 (2012-2013-2014), $269-323$.

Van der Made, J. (2015b). The rhinoceros Stephanorhinus aff. etruscus from the latest Early Pleistocene of Cueva Victoria (Murcia, Spain). El rinoceronte Stephanorhinus aff. etruscus del último Pleistoceno temprano de Cueva Victoria (Murcia, España). Mastia, Revista del Museo Arqueológico Municipal de Cartagena "Enrique Escudero de Castro" (volumen temático: Ferrández-Cañadell, C., \& L. Gibert (Eds.), Geología y Palaeontología de Cueva Victoria) 11-12-13 (2012-2013-2014), 359383.

Van der Made, J. (2019). The dwarfed "giant deer" Megaloceros matritensis n.sp. from the Middle Pleistocene of Madrid - a descendant of M. savini and contemporary to M. giganteus. Quaternary International, 520, 110-139.

Van der Made, J., Rosell, J. \& Blasco, R. (2017). Faunas from Atapuerca at the Early-Middle Pleistocene limit: The ungulates from level TD8 in the context of climatic change. Quaternary International, 433, 296-346.

Van der Made, J., \& Tong, H.W. (2008). Phylogeny of the giant deer with palmate brow tines Megaloceros from west and Sinomegaceros from east Eurasia. Quaternary International, 179, 135-162.

Van Kolfschoten T., \& Markova, A.K. (2005). Response of the European mammalian fauna to the mid-Pleistocene transition. In: Head, M.J., \& P.L. Gibbard, (Eds.), Early-Middle Pleistocene transition: The land-ocean evidence. London: Geological Society Special Publication 247, (pp. 221-229).

Viala, M.B., Giner, P.J., Cañada, L.M.S., \& Piqueras, L.H. (2020). Understanding woodworking in Paleolithic times by means of 
use-wear analysis. Journal of Archaeological Science: Reports, 29, 102-119.

Vicente Gabarda, M., Martínez Valle, R., Guillem Calatayud, P.M., Garay Martí, P., Pueyo, F., \& Casabo, J. (2016). The Lower Palaeolithic site Alto de las Picarazas (Andilla-Chelva, Valencia). Quaternary International, 393, 83-94.

Walker, M.J. (2009). Long-term memory and Middle Pleistocene "Mysterians". In: de Beaune, S.A., F.L.Coolidge, \&T.Wynn (Eds.), Cognitive archaeology and human evolution. Cambridge and New York: Cambridge University Press (pp. 75-84).

Walker, M.J. (2016). Palaeoneurophysiology and cognitive evolution in Pleistocene Homo: Biological and palaeoanthropological perspectives on the role of "haptic" working memory in the evolution of long-term procedural memory; drawing neuroscience and palaeoanthropology together. (pp.177-193) In: Ribot F. (Ed.), Homenaje al Dr. José Gibert Clols: Una vida dedicada a la ciencia y a los primeros europeos. Granada: Publicaciones de la Diputación de Granada, (pp.177-193).

Walker, M.J. (2017). Palaeolithic pioneers: Behaviour, abilities, and activity of early Homo in European landscapes around the western Mediterranean basin 1.3-0.05 Ma. Oxford: Archaeopress.

Walker, M.J., Anesin, D., Angelucci, D.E., Avilés-Fernández, A., Berna, F., Buitrago-López, A.T., Carrión, J.S., Eastham, A., Fernández-Jalvo, Y., Fernández-Jiménez, S., García-Torres, J., Haber-Uriarte, M., López-Jiménez, A., López-Martínez, M.V., Martín-Lerma, I., Ortega-Rodrigáñez, J., Polo-Camacho, J.L., Rhodes, S.E., Richter, D., Rodríguez-Estrella, T., Romero-Sánchez, G., San-Nicolás-del-Toro, M., Schwenninger, J-L., Skinner, A,R., Van-der-Made, J., \& Zack, W. (2016a). A view from a cave: Cueva Negra del Estrecho del Río Quípar (Caravaca de la Cruz, Murcia, southeastern Spain). Reflections on fire, technological diversity, environmental exploitation, and palaeoanthropological approaches. Human Evolution, 31, 167.

Walker, M.J., Anesin, D., Angelucci, D.E., Avilés-Fernández, A., Berna, F., Buitrago-López, A.T., Fernández-Jalvo, Y., HaberUriarte, M., López-Jiménez, A., López-Martínez, M., Martín-Lerma, I., Ortega-Rodrigáñez, J., Polo-Camacho, J. L., Rhodes, S.E., Richter, D., Rodríguez-Estrella, T., Schwenninger, J-L., \& Skinner, A.R. (2016b). Combustion at the late Early Pleistocene Palaeolithic site of Cueva Negra del Estrecho del Río Quípar (Caravaca de la Cruz, Murcia, Spain). Antiquity, 90, 571-589.

Walker, M.J., Duval, M., Grün, R., Haber-Uriarte, M., López-Jiménez, A., \& López-Martínez, M. (2019). New chronological constraints for the Lower Palaeolithic site of Cueva Negra del Estrecho del Río Quípar, Caravaca de la Cruz, Murcia, Spain: Preliminary ESR dating of the late Early Pleistocene fauna. Proceedings of the European Society for the Study of Evolution 8, 197.

Walker, M.J., Gibert, J., Eastham, A., Rodríguez-Estrella, T., Carrión, J.S., Yll, E.I., Legaz, A.J., López, A., López, M., \& Romero, G. (2004). Neanderthals and their landscapes: Middle palaeolithic land use in the Segura drainage basin and adjacent areas of southeastern Spain. In: Conard, N.J. (Ed.) Settlement dynamics of the Middle Palaeolithic and Middle Stone Age Vol. 2. Tübingen: Kerns Verlag, "Tübingen Studies in Prehistory 2" (pp. 461-511).

Walker, M.J., López-Martínez, M.V., Carrión-García, J.S., Rodríguez-Estrella, T., San-Nicolás-del-Toro, M., Schwenninger, J-L., López-Jiménez, A., Ortega-Rodrigáñez, J., Haber-Uriarte, M., Polo-Camacho, J-L., García-Torres, J., Campillo-Boj, M., Avilés-Fernández, A., \& Zack, W., (2013). Cueva Negra del Estrecho del Río Quípar (Murcia, Spain): A late Early Pleistocene hominin site with an "Acheulo-Levalloiso-Mousteroid” Palaeolithic assemblage. Quaternary International, 294, 135-159.

Walker, M.J., Rodríguez-Estrella, T., Carrión García, J.S., Mancheño-Jiménez, M-A., Schwenninger, J-L., López-Martínez, M., LópezJiménez, A., San Nicolás-del Toro, M., Hills, M.D., \& Walkling, T. (2006). Cueva Negra del Estrecho del Río Quípar (Murcia, Southeast Spain): An Acheulian and Levalloiso-Mousteroid assemblage of Palaeolithic artifacts excavated in a Middle Pleistocene faunal context with hominin skeletal remains. Eurasian Prehistory, 4, 3-43.

Zack, W., Andronikov, A., Rodríguez-Estrella, T., López-Martínez, M., Haber-Uriarte, M., Holliday, V., Lauretta, D., \& Walker, M.J. (2013). Stone procurement and transport at the late Early Pleistocene site of Cueva Negra del Estrecho del río Quípar (Murcia, SE Spain). Quartär, 60, 7-28.

Zaidner, Y. (2013). Adaptive flexibility of Oldowan hominins: Secondary use of flakes at Bizat Ruhama. Public Library of Science One (PLoS ONE),8, e66851. 


\section{Supplementary Information}

\section{Supplementary Information 1: Combined US-ESR dating of tooth sample CN1511}

\subsection{Material \& methods}

\subsubsection{Samples}

Sample CN1511 is an equid tooth from lithostratigraphical Unit IV, archaeological layer 4b (Walker et al., 2013) within sedimentary stratigraphical Complex 3-1 (Angelucci et al. 2013). The gamma dose rate of the layer was measured in situ, while additional an additional sediment sample was collected for further laboratory analyses (water content and radioelement concentrations).

\subsubsection{Sample preparation}

Two cross sections (A and B) were extracted from tooth CN1511 for pre-screening with Laser Ablation ICP-MS U-series analyses to assess the suitability of the samples for ESR dating. This was followed by the standard ESR dating procedure for enamel powder (e.g., Duval et al. 2011). The enamel layer of the vestibular side of the tooth was mechanically separated from the other dental tissues and both inner and outer surfaces were removed with a dentist drill to eliminate the volume that received an external alpha dose. The enamel samples were ground and the sieve fraction of $<200 \mu \mathrm{m}$ was used for ESR analysis. The powder was split into eleven aliquots and irradiated with a Gammacell $1000 \mathrm{Cs}-137$ gamma source (dose rate $=6.41 \pm 0.15 \mathrm{~Gy} / \mathrm{min}$ ) to the following doses: $0.0,80.1,150.2,250.5,350.7,500.8,701.1,901.6,1502.6,3005.2$ and 5008.6 Gy.

\subsubsection{U-series analyses of dental tissues}

Laser Ablation (LA) U-series analyses were carried out at the Research School of Earth Sciences at the Australian National University (Australia), using a custom-built laser sampling system interfaced between an ArF Excimer laser and a MC-ICP-MS Finnigan Neptune (for details, see Eggins et al. 2003, 2005), following the principles and procedures described in Grün et al. (2014). In each tooth, various LA transects made of several ablation spots were performed across enamel, dentine and cement of CN1511A \& B (Figures 4, 5 and Supplementary Information Figure S1). The resulting analytical data obtained for each tissue were integrated to provide the U-series data inputs for the ESR age calculations (Table 1 and Supplementary Information Tables S1 and S2).

\subsubsection{ESR dose evaluation}

Dose evaluation was carried out through the multiple aliquot additive dose (MAAD) method. ESR measurements were carried out at room temperature with an EMXmicro 6/1 Bruker ESR spectrometer coupled to a standard rectangular ER 4102ST cavity. The following procedure was used to minimise the analytical uncertainties: (i) all aliquots of a given sample were carefully weighted into their corresponding tubes and a variation of $<1 \mathrm{mg}$ was tolerated between aliquots; (ii) ESR measurements were performed using a Teflon sample tube holder inserted from the bottom of the cavity to ensure that the vertical position of the tubes remains exactly the same for all aliquots. The following acquisition parameters were used: $1 \mathrm{scan}, 1 \mathrm{~mW}$ microwave power, 1024 points resolution, $15 \mathrm{mT}$ sweep width, $100 \mathrm{kHz}$ modulation frequency, $0.1 \mathrm{mT}$ modulation amplitude, $20 \mathrm{~ms}$ conversion time and $5 \mathrm{~ms}$ time constant. All aliquots of a given sample were measured within a short time interval $(<1 \mathrm{~h})$. This procedure was repeated twice over successive days without removing the enamel from the ESR tubes between measurements in order to evaluate measurement and equivalent dose $\left(\mathrm{D}_{\mathrm{E}}\right)$ precisions (Table S3).

The ESR intensities were extracted from T1-B2 peak-to-peak amplitudes of the ESR signal (Grün 2000a), and then normalised to the corresponding number of scans and aliquot masses. $\mathrm{D}_{\mathrm{E}}$ values were obtained by fitting a single saturating exponential (SSE) through the ESR intensities with the Microcal OriginPro 9.1 software, which is based on a Levenberg-Marquardt algorithm by chisquare minimisation. Data were weighted by the inverse of the squared ESR intensity $\left(1 / \mathrm{I}^{2}\right)$ (Grün and Brumby 1994). ESR dose response curves (DRCs) are shown in Supplementary Information Fig. S1.

\subsubsection{Dose rate evaluation and age calculations}

The total dose rate value was derived from a combination of in situ and laboratory measurements. The external gamma dose rate was calculated by using the "threshold technique" (Duval and Arnold 2013) and derived from in situ measurements performed with a NaI probe connected to an Inpsector-1000 multichannel analyser. Bulk solution elemental ICP-MS analyses of raw sediment and dental tissues were performed by Genalysis Laboratory Services (Perth, Australia) following a four-acid digestion preparation procedure. $\mathrm{U}$, Th and $\mathrm{K}$ concentrations were obtained for the sediment samples, while only U concentration was measured for dental tissues, which are known to be virtually free of Th and K (e.g., Grün and Mc Dermott 1994). Several subsamples of each tissue were analysed and returned limited internal variability $(<5 \%)$.

The following parameters were used for the dose rate calculations: an alpha efficiency of $0.13 \pm 0.02$ (Grün and KatzenbergerApel 1994), Monte-Carlo beta attenuation factors from Marsh (1999), dose-rate conversion factors from Adamiec and Aitken (1998) and water corrections from Grün (1994). An estimated water content of $5 \pm 3 \mathrm{wt} . \%$ was considered in dentine. Current water content measured in all sediment samples collected at the site vary within a narrow range from 0.2 to $5.7 \%$ but is unlikely to be fully representative of long-term moisture conditions at the site because the outcropping sedimentary section resulting from the excavation has most likely partially dried out prior to sampling. Consequently, a higher value of $15 \pm 5 \%(1 \sigma)$ was considered as a more suitable long-term water content, and assumed instead for the age calculation. In situ gamma dose rate values were corrected accordingly. A $1 \sigma$ relative uncertainty of $30 \%$ has been assigned to the water content estimate in order to cover any potential 
variations in moisture conditions in the cave during burial. The thickness of the overburden was assumed to be ca. $10 \mathrm{~m}$ and a depth of $15 \pm 5 \mathrm{~m}$ was considered for age calculation. Cosmic dose rate was calculated using Prescott and Hutton (1994).

Age calculations were performed with USESR, a Matlab-based program (Shao et al. 2014) using the US-ESR model defined by Grün et al (1988). This model assumes a gradual U-uptake over time following a one parameter diffusion equation. An overview of the dating method applied to fossil teeth may be found in Duval (2015). Data inputs and final US-ESR age results are displayed in Table 1. Additional CSUS-ESR age calculations were also carried out using DATA, a DOS-based program (Grün 2009). The CSUS-ESR model defined by Grün (2000b) is based on the assumption that all of the uranium migrated into the sample at a time given by the closed system U-series age. The CSUS-ESR age the maximum age that can be derived from a given U-series and ESR data set. Age calculations using the US-ESR and CSUS-ESR models encompass all possible uptake scenarios. If the dose rates derived from the internal uranium concentrations are low, the differences between the US-ESR and CSUS-ESR models are small. This is not the case when the dose rate of a tooth is dominated by the uranium in the various dental tissues.

\subsection{Results}

\subsection{1. $\quad$ Pre-screening procedure}

Following the standard analytical procedure for expectedly "old" (Early Pleistocene or older) samples (e.g. Duval et al. 2012), laser ablation U-series analyses were first performed on the tooth cross sections in order to evaluate their suitability for ESR dating. Results are graphically displayed in Figures 4 and 5 and Supplementary Information Figure S1, while numerical values obtained for each indivual laser ablation spot are given in Tables S1 and S2.

Two factors, frequently occurring in Early Pleistocene samples, strongly limit the reliability of the ESR age results: (i) uranium leaching and (ii) high uranium concentration $(>2 \mathrm{ppm})$ in the enamel. They typically either preclude the use of the US and CSUS models, or may lead to massive age underestimation (Duval et al. 2012). Interestingly, neither of these two conditions were observed in CN1511. CN1511A and transect \#1 on CN1511B were both performed across the vestibular side of the tooth. They both show relatively homogeneous U-series data across each tissue. Apparent U-series ages overall range from 190 to $320 \mathrm{ka}$ in all tissues (Table S1 and S2), while the uranium concentration in the enamel remains within 0.5-1.5 ppm. Additionnally, U-series data show relatively high $\mathrm{U} / \mathrm{Th}$ ratio for all dental tissues, indicating thus the absence of significant contamination by detrital Th. In comparison, LA transect \#2 of CN1511B shows more scattered U-series data within each tissue and slightly higher uranium concentration in the enamel, suggesting that the inner enamel layer is maybe less suitable for ESR dating. Consequently, ESR dating was focused on the vestibular enamel layer.

The apparent U-series ages obtained should be regarded as minimum age constraints for the fossils, as uranium uptake may sometimes be significantly delayed after the death of the organism. The enamel tissue in fragments A and B display an apparent age 188-213 ka, while dentine and cement vary between 308-319 and 242-247 ka, respectively. Consequently, the ages results obtained for the dentine tissues suggest that the fossil tooth is at least older than $320 \mathrm{ka}$.

\subsubsection{ESR dose evaluation}

The two repeated ESR measurements yielded measurement precision of $\sim 1.3 \%$ for the two samples. This resulted in a limited $D_{E}$ variability of $1.5-2.7 \%$, which was significantly smaller than usually observed for samples with $D_{E}$ values $>1500$ Gy (Duval et al. 2013). Consequently, the $D_{E}$ values for age calculation were obtained by pooling all ESR intensities derived from the two repeated measurements into a single dose response curve (DRC) (Fig. S2). Following the recommendations of Duval and Grün (2016), the DRC of each sample was restricted to $D_{\max }=3005$ Gy to achieve the appropriate $D_{\max } / \mathrm{D}_{\mathrm{E}}$ ratio (see Table S3). The two samples display high and internally very consistent $\mathrm{D}_{\mathrm{E}}$ values of $1631 \pm 141$ (CN1511A) and $1601 \pm 92$ Gy (CN1511B). For comparison, fitting performed using $\mathrm{D}_{\max }=5009$ Gy resulted in negligible differences $(<1 \%)$ on the $\mathrm{D}_{\mathrm{E}}$ estimates.

\subsubsection{US-ESR age calculations}

Combined US-ESR age calculations performed on the two sub-samples of CN1511 returned age estimates of around 400 to 410 ka. These very close results (within 1.2\%) are due to the highly homogeneous U-series and ESR data collected for each dental tissue of the two samples. Consequently, all these data can be merged into one single data set that may be reasonably assumed to be representative of the whole tooth. The resulting US-ESR and CSUS-ESR calculations yielded age estimates of $406 \pm 40$ and 1446 $\pm 310 \mathrm{ka}$, respectively (Table 1). As mentioned above, US and CSUS models are typically considered to encompass all possible uptake scenarios and the true age of tooth CN1511 should thus be somewhere between these two estimates.

\subsection{4. $\quad$ Sensitivity tests}

Age sensitivity tests were performed in order to evaluate the impact of several parameters on the calculated ages. In this context, uranium uptake modelling is undoubtedly the major source of age uncertainty, as illustrated by the massive age difference between the US-ESR and CSUS-ESR estimates ( $>1 \mathrm{Ma}$ ). This is simply because $90 \%$ of the US-ESR dose rate comes from dental tissues (19\%, 42\% and $29 \%$ from enamel, dentine and cement). In comparison, all other sources of uncertainty have a more limited impact on the calculated results.

For example, cosmic dose rate represents only $1 \%$ of the total dose rate. Even with considering a value three times higher, the weight of this component would not exceed $5 \%$ of the total dose rate. This illustrates its almost negligible impact on the calculated ages.

During sample preparation the thickness of the external cement has been measured to between 1.14-1.21 mm, i.e., slightly smaller than the 2-mm typically considered for fulfilling the infinite matrix assumption. Consequently, the cement should only contribute to ca. $92 \%$ of the external beta dose rate from the outer side of the enamel layer (Duval and Martin 2019). In other words, 
about $8 \%$ of the beta dose rate should come from the sediment. Correcting for this effect has only a minor effect on the overall age. Simulations performed with no cement attached to the enamel layer indicate a sediment beta dose of $66 \pm 6 \mu \mathrm{Gy} / \mathrm{a}$, i.e., only $5.8 \%$ of the infinite matrix cement dose rate $(1142 \pm 233 \mu \mathrm{Gy} / \mathrm{a})$. However, despite this difference, the US-ESR age result obtained by considering relative proportions of $92 \%$ from cement and $8 \%$ from sediment for the external outer beta dose rate, would be only slightly older by about $2 \%$.

Finally, initial age calculations were carried out assuming a long-term water content of $5 \pm 3 \%$ in dentine and cement and $15 \pm 5 \%$ in sediment. Results show that the beta dose rate from dentine and cement represents $71 \%$ of the total dose rate, while the gamma dose rate is only ca. $9 \%$ of the total dose rate (Table 1). Considering a $10 \%$ water content in dental tissues yields a combined USESR age result of $427 \pm 45 \mathrm{ka}$, i.e. $5 \%$ older than the $406 \pm 40$ reported in Table 1 (column 4) for the combined sample. In comparison, a $10 \%$ and $20 \%$ water content in sediment would only have a negligible impact $(<1 \%)$ on the resulting ages $(404 \pm 40$ and $408 \pm 40 \mathrm{ka}$, respectively). These sensitivity tests show the overall limited influence of water content variation on the calculated US-ESR ages, which systematically remain within error. It is worth mentioning here that initial age calculations were performed using large $1 \sigma$ errors on the water content values in order to reasonably encompass any potential variation of this parameter over time: at a $2 \sigma$ confidence level, the water content values range from 0 to $11 \%$ in dental tissues and between 5 and $25 \%$ in sediment. Consequently, the age results and associated errors displayed in Table 1 do include a significant uncertainty on the water content.

\subsubsection{Comparison with independent age control}

The US-ESR age estimate suggests a Middle Pleistocene age for CN1511. This appears to be much younger than the previous independent age assessment based on a combination of palaeomagnetism and biochronology, which suggested a late Early Pleistocene chronology for the whole sedimentary infilling (i.e. older than the Bruhes/Matuyama boundary at $\sim 780 \mathrm{ka}$ ). This apparent inconsistency may be related with some specific U-series features displayed by CN1511. Laser ablation pre-screening analyses initially suggested that the sample was suitable for the application of the US-ESR method, as dental tissues of CN1511 do not display any evidence of uranium leaching, and the Uranium concentration in the enamel was below 2 ppm. However, the high uranium concentration in the dentine and cement, combined with apparent U-series ages $>200 \mathrm{ka}\left({ }^{230} \mathrm{Th} /{ }^{234} \mathrm{U}\right.$ activity ratios close or slightly above unity), led to the calculation of p-parameters showing an early uptake process (between -0.6 and -0.9; Table 1). This results in large dose rate values for all dental tissues (representing about $90 \%$ of the total dose rate).

One question is whether the older apparent U-series age estimates in dentine compared with enamel and cement may reflect a recent uranium leaching overprint. To evaluate this potential impact, we ran an age simulation using the apparent ages measured in the enamel for all the other dental tissues. The resulting US-ESR age get older by about 32\% (536 ka) but remains Middle Pleistocene. However, we presently do not have any evidence suggesting that dentine has been affected by a recent overprint. Instead, dentine and enamel show very close ${ }^{234} \mathrm{U} /{ }^{238} \mathrm{U}$ activity ratios, suggesting a similar source for the uranium uptake, and the younger U-series ages in enamel may simply be the consequence of a delayed uranium diffusion process from the dentine (Duval et al. 2011).

Given the current ESR and U-series data set collected for CN1511, an Early Pleistocene age estimate can only be achieved if the uranium uptake process in dental tissues has been similar to the conditions described by the CSUS model, i.e. a period of little initial U-uptake followed by a rapid uptake around $300 \mathrm{ka}$ ago The CSUS-ESR age estimate of $1446 \pm 310 \mathrm{ka}$ is the maximum age constraint for CN1511. Its true age lies somewhere between $406 \pm 40$ and $1446 \pm 310 \mathrm{ka}$, which is compatible with the independent biochronological and magnetostratigraphical evidence, but also shows the limited value of ESR age estimates on teeth where the total dose rate is dominated by the various U sources in the dental tissues. Given the current ESR and U-series data set collected for CN1511, an Early Pleistocene age estimate can only be achieved if the uranium uptake process in dental tissues has been similar to the conditions described by the CSUS model, i.e. a period of little initial U-uptake followed by a rapid uptake around $300 \mathrm{ka}$ ago The CSUS-ESR age estimate of $1446 \pm 310 \mathrm{ka}$ is the maximum age constraint for CN1511. Its true age lies somewhere between $406 \pm 40$ and $1446 \pm 310 \mathrm{ka}$, which is compatible with the independent biochronological and magnetostratigraphical evidence, but also shows the limited value of ESR age estimates on teeth where the total dose rate is strongly dominated by the various U sources in the dental tissues.

\section{References for Supplementary Information 1}

Adamiec, G. and Aitken, M. J. (1998). Dose-rate conversion factors. Ancient TL, 16 (2), 37-50.

Duval, M. (2015). Electron spin resonance (ESR) dating of fossil tooth enamel. In: Rink, W.J., \& J.W. Thompson (Eds.) Encyclopedia of scientific dating methods. Dordrecht: Springer (pp. 239-246).

Duval, M. and Grün, R. (2016). Are published ESR dose assessments on fossil tooth enamel reliable? Quaternary Geochronology, 31, 19-27.

Duval, M., Aubert, M., Hellstrom, J., \& Grün, R. (2011). High resolution LA-ICP-MS mapping of U and Th isotopes in an early Pleistocene equid tooth from Fuente Nueva-3 (Orce, Andalusia, Spain). Quaternary Geochronology, 6 (5), $458-467$.

Duval, M., Falguères, C., \& Bahain, J.-J. (2012). Age of the oldest hominin settlements in Spain: Contribution of the combined Useries/ESR dating method applied to fossil teeth. Quaternary Geochronology, 10 (0), 412-417.

Duval, M., Guilarte Moreno, V., \& Grün, R. (2013). ESR dosimetry of fossil enamel: some comments about measurement precision, long-term signal fading and dose-response curve fitting. Radiation Protection Dosimetry, 157 (4), $463-476$.

Eggins, S., Grün, R., Pike, A.W.G., Shelley, M., \& Taylor, L. (2003). 238U, 232Th profiling and U-series isotope analysis of fossil teeth by laser ablation-ICPMS. Quaternary Science Reviews, 22 (10-13), 1373-1382.

Eggins, S.M., Grün, R., McCulloch, M.T., Pike, A.W.G., Chappell, J., Kinsley, L., Mortimer, G., Shelley, M., Murray-Wallace, C.V., Spötl, C., \& Taylor, L. (2005). In situ U-series dating by laser-ablation multi-collector ICPMS: new prospects for 
Quaternary geochronology. Quaternary Science Reviews, 24 (23-24), 2523-2538.Guérin, G., Mercier, N., \& Adamiec, G. (2011).

Dose-rate conversion factors: Update. Ancient TL, 29 (1), 5-8.

Grün, R. (1994). A cautionary note: Use of 'water content' and 'depth for cosmic ray dose rate' in AGE and DATA programs. Ancient $T L, 12(2), 50-51$.

Grün, R. (2009). The DATA program for the calculation of ESR age estimates on tooth enamel. Quaternary Geochronology, 4 (3), 231-232.

Grün, R. (2000a). Methods of dose determination using ESR spectra of tooth enamel. Radiation Measurements, 32 (5-6), 767-772.

Grün, R. (2000b). An alternative model for open system U-series/ESR age calculations: (closed system U-series)-ESR, CSUS-ESR. Ancient TL 18(1): 1-4.

Grün, R. and Brumby, S. (1994). The assessment of errors in past radiation doses extrapolated from ESR/TL dose-response data. Radiation Measurements, 23 (2-3), 307-315.

Grün, R. and Katzenberger-Apel, O. (1994). An alpha irradiator for ESR dating. Ancient TL, 12 (2), 35-38.

Grün, R., Schwarcz, H.P., \& Chadam, J. (1988). ESR dating of tooth enamel: Coupled correction for U-uptake and U-series disequilibrium. International Journal of Radiation Applications and Instrumentation. Part D. Nuclear Tracks and Radiation Measurements, 14 (1-2), 237-241.

Grün, R., Eggins, S., Kinsley, L., Mosely, H., \& Sambridge, M. (2014). Laser ablation U-series analysis of fossil bones and teeth. Palaeogeography, Palaeoclimatology, Palaeoecology, 416, 150-167.

Marsh, R.E. (1999). Beta-gradient isochrons using electron paramagnetic resonance: Towards a new dating method in archaeology. McMaster University, M.Sc. thesis.

Prescott, J.R. and Hutton, J.T. (1994). Cosmic ray contributions to dose rates for luminescence and ESR dating: Large depths and long-term time variations. Radiation Measurements, 23 (2-3), 497-500.

Shao, Q., Bahain, J.-J., Dolo, J.-M., \& Falguères, C. (2014). Monte Carlo approach to calculate US-ESR age and age uncertainty for tooth enamel. Quaternary Geochronology, 22, 99-106.

Singer, B. S. (2014). A Quaternary geomagnetic instability time scale. Quaternary Geochronology, 21 (0), $29-52$.

Stimpson, C. M., A. Lister, A. Parton, L. Clark-Balzan, P. S. Breeze, N. A. Drake, H. S. Groucutt, R. Jennings, E. M. L. Scerri, T. S. White, M. Zahir, M. Duval, R. Grün, A. Al-Omari, K. S. M. Al Murayyi, I. S. Zalmout, Y. A. Mufarreh, A. M. Memesh, and M. D. Petraglia (2016). Middle Pleistocene vertebrate fossils from the Nefud Desert, Saudi Arabia: Implications for biogeography and palaeoecology. Quaternary Science Reviews, 143 (Supplement C), 13-36.

\section{Captions for Supplementary Information 1}

\section{Table Captions}

Table S1: LA ICP-MS U-series results obtained for transect \#1 performed on sample CN1511A. No individual age calculations were carried out for $U$ concentrations of $\leq 0.5 \mathrm{ppm}$ or an absolute value of $\mathrm{U} / \mathrm{Th} \leq 300$ but not negative (indicated in red). Age results in italics should be treated with caution. Negative U/Th are due to the background being higher than the measurement. All errors are 1- $\sigma$. Key: $\mathrm{EN}=$ enamel; $\mathrm{DE}=$ dentine; $\mathrm{CE}=$ cement. Some of these results are graphically displayed in Figure $\mathrm{S} 1$.

Table S2: LA ICP-MS U-series results obtained for transects \#1 and \#2 performed on sample CN1511B. No individual age calculations were carried out for $U$ concentrations of $\leq 0.5 \mathrm{ppm}$ or an absolute value of $\mathrm{U} / \mathrm{Th} \leq 300$ but not negative (indicated in red). Age results in italics should be treated with caution. Negative U/Th are due to the background being higher than the measurement. All errors are $1-\sigma . \mathrm{Key}: \mathrm{EN}=$ enamel; $\mathrm{DE}=$ dentine; $\mathrm{CE}=$ cement. Some of these results are graphically displayed in Figure S2 and S3.

Table S3: ESR results derived from the analyses of the two samples. Measurement precision is the average 1- $\sigma$ standard deviation for all aliquots of a given sample after the three repeated measurements. $D_{E}$ precision is the variability of the $D_{E}$ values derived from the repeated measurements of a given sample. The $\mathrm{D}_{\mathrm{E}}$ error is a combination of the fitting error and the error on the calibration of the irradiation source $(2.3 \%)$.

\section{Figure Caption}

Figure S1: ESR dose response curves obtained for samples CN1511A and CN1511B. The lowermost graph displays the resulting DRC after pooling all the repeated ESR intensities obtained for each sample. 


\begin{tabular}{|c|c|c|c|c|c|c|c|c|}
\hline Spot & Domain & $\mathrm{U}(\mathrm{ppm})$ & $\mathrm{U} / \mathrm{Th}$ & ${ }^{234} \mathrm{U} /{ }^{238} \mathrm{U}$ & \pm & ${ }^{230} \mathrm{Th} /{ }^{238} \mathrm{U}$ & \pm & Age (ka) \\
\hline 1 & CE1 & 73.9 & 39653 & 1.594 & 0.305 & 1.600 & 1.958 & 258 \\
\hline 2 & CE1 & 58.6 & 39911 & 1.608 & 0.038 & 1.544 & 0.315 & 226 \\
\hline 3 & CE1 & 66.5 & 31932 & 1.587 & 0.023 & 1.584 & 0.017 & 254 \\
\hline 4 & CE1 & 62.7 & 38212 & 1.610 & 0.200 & 1.589 & 0.312 & 244 \\
\hline 5 & CE1 & 65.1 & 51869 & 1.603 & 0.055 & 1.591 & 0.474 & 249 \\
\hline 6 & CE1/EN1 & 47.4 & 28408 & 1.592 & 4.521 & 1.603 & 36.483 & 261 \\
\hline 7 & EN1 & 0.4 & -842 & 1.368 & 0.048 & 1.222 & 0.083 & - \\
\hline 8 & EN1 & 1.1 & 9454 & 1.568 & 0.133 & 1.482 & 0.617 & 218 \\
\hline 9 & EN1/DE1 & 19.8 & -36034 & 1.567 & 0.051 & 1.592 & 0.034 & 272 \\
\hline 10 & DE1 & 79.5 & -159942 & 1.561 & 0.029 & 1.600 & 0.017 & 281 \\
\hline 11 & DE1 & 83.7 & 1330304 & 1.572 & 0.022 & 1.612 & 0.020 & 280 \\
\hline 12 & DE1 & 85.5 & 42778 & 1.552 & 0.004 & 1.649 & 0.008 & 327 \\
\hline 13 & DE1 & 72.9 & 22617 & 1.519 & 0.006 & 1.616 & 0.009 & 336 \\
\hline 14 & DE1 & 80.4 & 61201 & 1.520 & 0.004 & 1.628 & 0.012 & 347 \\
\hline \multicolumn{9}{|c|}{ Merged values } \\
\hline & CE1 & 65.4 & & 1.600 & 0.020 & 1.583 & 0.016 & 247 \\
\hline & EN1 & 0.8 & & 1.513 & 0.067 & 1.410 & 0.117 & 213 \\
\hline & DE1 & 80.6 & & 1.542 & 0.004 & 1.627 & 0.008 & 319 \\
\hline
\end{tabular}

Table S1: LA ICP-MS U-series results obtained for transect \#1 performed on sample CN1511A. No individual age calculations were carried out for $U$ concentrations of $\leq 0.5 \mathrm{ppm}$ or an absolute value of U/Th $\leq 300$ but not negative (indicated in red). Age results in italics should be treated with caution. Negative U/Th are due to the background being higher than the measurement. All errors are 1- $\sigma$. Key: EN= enamel; $D E=$ dentine; $C E=$ cement. Some of these results are graphically displayed in Figure S1. 


\begin{tabular}{|c|c|c|c|c|c|c|c|c|c|}
\hline Spot & Transect & Domain & $\mathrm{U}(\mathrm{ppm})$ & $\mathrm{U} / \mathrm{Th}$ & ${ }^{234} \mathrm{U} /{ }^{238} \mathrm{U}$ & \pm & ${ }^{230} \mathrm{Th} /{ }^{238} \mathrm{U}$ & \pm & Age (ka) \\
\hline 1 & \multirow[t]{15}{*}{1} & CE1 & 61.5 & 20669 & 1.626 & 0.006 & 1.598 & 0.010 & 240 \\
\hline 2 & & CE1 & 66.3 & 24416 & 1.620 & 0.006 & 1.600 & 0.010 & 244 \\
\hline 3 & & CE1 & 62.8 & 29573 & 1.615 & 0.007 & 1.618 & 0.014 & 255 \\
\hline 4 & & CE1 & 72.3 & 47598 & 1.602 & 0.008 & 1.550 & 0.011 & 231 \\
\hline 5 & & EN1 & 1.0 & -3065 & 1.559 & 0.027 & 1.241 & 0.048 & 149 \\
\hline 6 & & EN1 & 1.4 & -118756 & 1.645 & 0.025 & 1.428 & 0.032 & 176 \\
\hline 7 & & EN1 & 1.1 & -1396 & 1.550 & 0.022 & 1.411 & 0.033 & 199 \\
\hline 8 & & EN1 & 0.9 & -3171 & 1.555 & 0.023 & 1.470 & 0.046 & 219 \\
\hline 9 & & EN1 & 2.4 & 68576 & 1.535 & 0.013 & 1.402 & 0.022 & 201 \\
\hline 10 & & DE1 & 79.2 & -165330 & 1.568 & 0.004 & 1.639 & 0.012 & 302 \\
\hline 11 & & DE1 & 70.4 & 71713 & 1.555 & 0.011 & 1.589 & 0.016 & 279 \\
\hline 12 & & DE1 & 73.3 & 37364 & 1.511 & 0.005 & 1.614 & 0.008 & 345 \\
\hline 13 & & DE1 & 72.1 & 83074 & 1.541 & 0.004 & 1.627 & 0.009 & 319 \\
\hline 14 & & DE1 & 73.2 & 102400 & 1.551 & 0.011 & 1.659 & 0.012 & 338 \\
\hline 15 & & DE1 & 77.8 & 137799 & 1.568 & 0.008 & 1.615 & 0.014 & 285 \\
\hline 16 & \multirow[t]{8}{*}{2} & EN2 & 1.6 & -3419 & 1.571 & 0.022 & 1.435 & 0.039 & 200 \\
\hline 17 & & EN2 & 2.5 & 1388 & 1.542 & 0.018 & 1.446 & 0.024 & 215 \\
\hline 18 & & EN2 & 0.6 & 748 & 1.442 & 0.019 & 0.941 & 0.053 & 107 \\
\hline 19 & & EN2 & 1.6 & 829 & 1.558 & 0.025 & 1.344 & 0.033 & 176 \\
\hline 20 & & CE2 & 67.8 & 48674 & 1.563 & 0.010 & 1.660 & 0.008 & 324 \\
\hline 21 & & CE2 & 67.1 & 91474 & 1.581 & 0.004 & 1.556 & 0.016 & 244 \\
\hline 22 & & CE2 & 68.9 & 71694 & 1.573 & 0.004 & 1.639 & 0.013 & 297 \\
\hline 23 & & CE2 & 70.4 & 32738 & 1.596 & 0.004 & 1.593 & 0.018 & 254 \\
\hline \multicolumn{10}{|c|}{ Merged values } \\
\hline & & CE1 & 65.7 & & 1.615 & 0.006 & 1.590 & 0.010 & 242 \\
\hline & & EN1 & 1.4 & & 1.567 & 0.012 & 1.394 & 0.020 & 188 \\
\hline & & DE1 & 74.3 & & 1.550 & 0.003 & 1.624 & 0.007 & 308 \\
\hline & & EN2 & 1.6 & & 1.544 & 0.018 & 1.371 & 0.024 & 188 \\
\hline & & CE2 & 68.5 & & 1.578 & 0.004 & 1.612 & 0.008 & 276 \\
\hline
\end{tabular}

Table S2: LA ICP-MS U-series results obtained for transects \#1 and \#2 performed on sample CN1511B. No individual age calculations were carried out for $U$ concentrations of $\leq 0.5 \mathrm{ppm}$ or an absolute value of U/Th $\leq 300$ but not negative (indicated in red). Age results in italics should be treated with caution. Negative U/Th are due to the background being higher than the measurement. All errors are 1- $\sigma$. Key: $E N=$ enamel; $D E=$ dentine; $C E=$ cement. Some of these results are graphically displayed in Figures 5 and $S 1$.

\begin{tabular}{|l|l|l|l|l|l|l|}
\hline Sample & Measurement precision (\%) & $\mathrm{D}_{\mathrm{E}}$ precision (\%) & Adj. R-Square & $\mathrm{D}_{\mathrm{E}}$ value $(\mathrm{Gy})$ & $\mathrm{D}_{\max }(\mathrm{Gy})$ & $\mathrm{D}_{\max } / \mathrm{D}_{\mathrm{E}}$ \\
\hline CN1511A & 1.3 & 1.5 & 0.991 & $1631 \pm 141$ & 3005 & 1.84 \\
\hline CN1511B & 1.3 & 2.7 & 0.996 & $1601 \pm 92$ & 3005 & 1.88 \\
\hline
\end{tabular}

Table S3: ESR results derived from the analyses of the two samples. Measurement precision is the average 1- $\sigma$ standard deviation for all aliquots of a given sample after the three repeated measurements. $D_{E}$ precision is the variability of the $D_{E}$ values derived from the repeated measurements of a given sample. The $D_{E}$ error is a combination of the fitting error and the error on the calibration of the irradiation source $(2.3 \%)$. 
Figure S1.
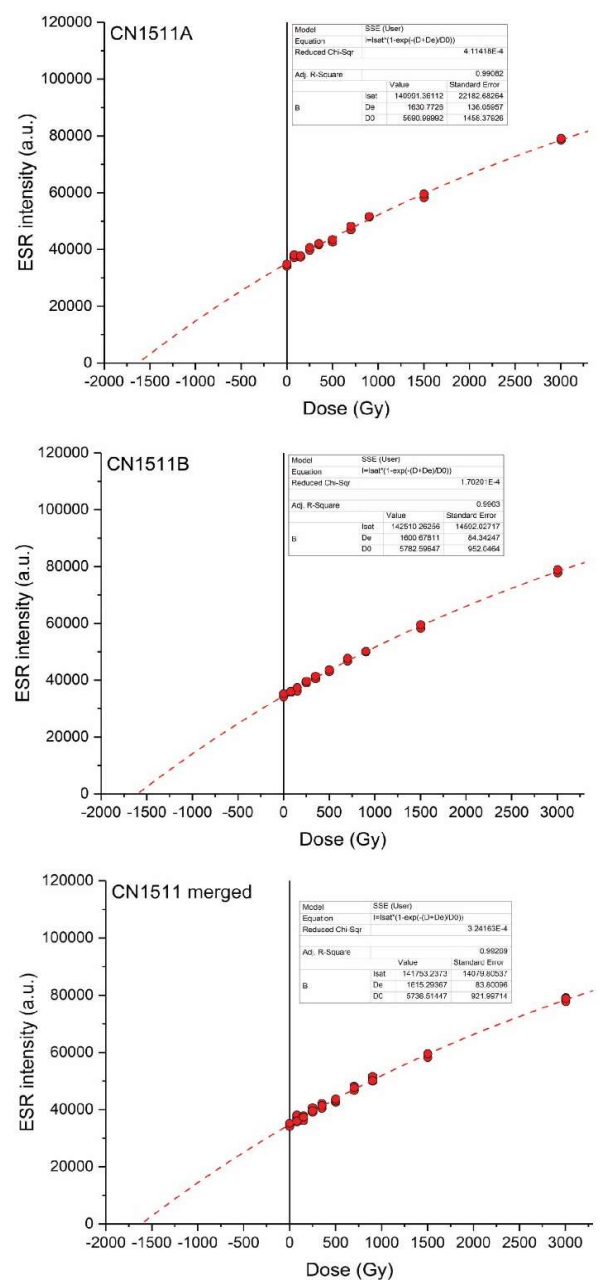

Figure S1: ESR dose response curves (DRCs) obtained for samples CN1511A and CN1511B. The lowermost graph displays the resulting DRC after pooling all the repeated ESR intensities obtained for each sample. 


\section{Supplementary Information 2: Material and methods for the palaeontology of large mammals}

Commonly accepted methods were used for the paleontological study of large mammals.For the Equidae, these follow Eisenmann et al. (1988), for the Rhinocerotidae they follow Van der Made (2010), and for the Cervidae they follow Van der Made \& Tong (2008) and Van der Made (2019).The fossils studied here were compared to others. Where those comparisons are made, the insititutions where the material was studied are indicated by the following acronyms:

FBFSU Forschungstelle Bilzingsleben, Friedrich Schiller Universität Jena

IGF Istituto di Geologia, now Museo di Storia Naturale, Firenze

IAMM Ice Age Museum, Moscow

IPHES Institut Català de Paleoecologia Humana i Evolució Social, Tarragona

IPRFWUB Institut für Paläontologie der Rheinischen Friedrich-Wilhelms Universität Bonn

IPS InstitutCatalà de Paleontologia Miquel Crusafont, Sabadell

IQW Institut für Quartärpaläontologie, Weimar (Forschungsinstitut Senckenberg, Forschungsstation für Quartärpaläontologie, Weimar- Senckenberg Forschungsinstitut und Naturmuseum, Forschungsstation für Quartärpaläontologie, Weimar)

LVH Landesmuseum für Vorgeschichte, Halle

MAC Museo de Arqueología de Cartagena

MAM Museo Arqueológico de Mucia

MMPC Museu Moliner Paperer, Capellades

MNCN Museo Nacional de Ciencias Naturales, Madrid

MNHN Muséum National d'Histoire Naturelle, Paris

MPUR Museo di Paleontologia, Istituto de Geologia e Paleontologia, Università di Roma

MSI Museo de San Isidro, Madrid

NBC Naturalis Biodiversity Center, Leiden

NHM Natural History Museum, London

NMM Naturhistorisches Museum, Mainz

SMNS Staatliches Museum für Naturkunde, Stuttgart

TUC Technische Universität Clausthal, Insitut für Geologie und Paläontologie

ZPALUWr Division of Palaeozoology, Department of Evolutionary Biology and Ecology, University of Wroclaw

\section{References for Supplementary Information 2}

Eisenmann, V., Alberdi, M.T., de Giuli, C., \& Staesche, U. (1988). Methodology. In: Woodburne, M., \& P. Sondaar (Eds), Studying fossil horses, Volume 1. Leiden: E.J. Brill (pp. 1-71).

Van der Made, J. (2010). The rhinos from the Middle Pleistocene of Neumark Nord (Saxony-Anhalt). Los rinocerontes del Pleistoceno Medio de Neumark Nord (Sajonia-Anhalt). Veröffentlichungen des Landesamtes für Archeologie 62 (NeumarkNord - ein interglaziales Öksoystem des mittelpaläolithischen Menschen) (pp. 432-527).

Van der Made, J. (2019). The dwarfed "giant deer" Megaloceros matritensis n.sp. from the Middle Pleistocene of Madrid - a descendant of M. savini and contemporary to M. giganteus. Quaternary International, 520, 110-139.

Van der Made, J. and Tong, H.W. (2008). Phylogeny of the giant deer with palmate brow tines Megaloceros from west and Sinomegaceros from east Eurasia. Quaternary International, 179, 135-162. 